\title{
Basement Domain Map of the Conterminous United States and Alaska
}

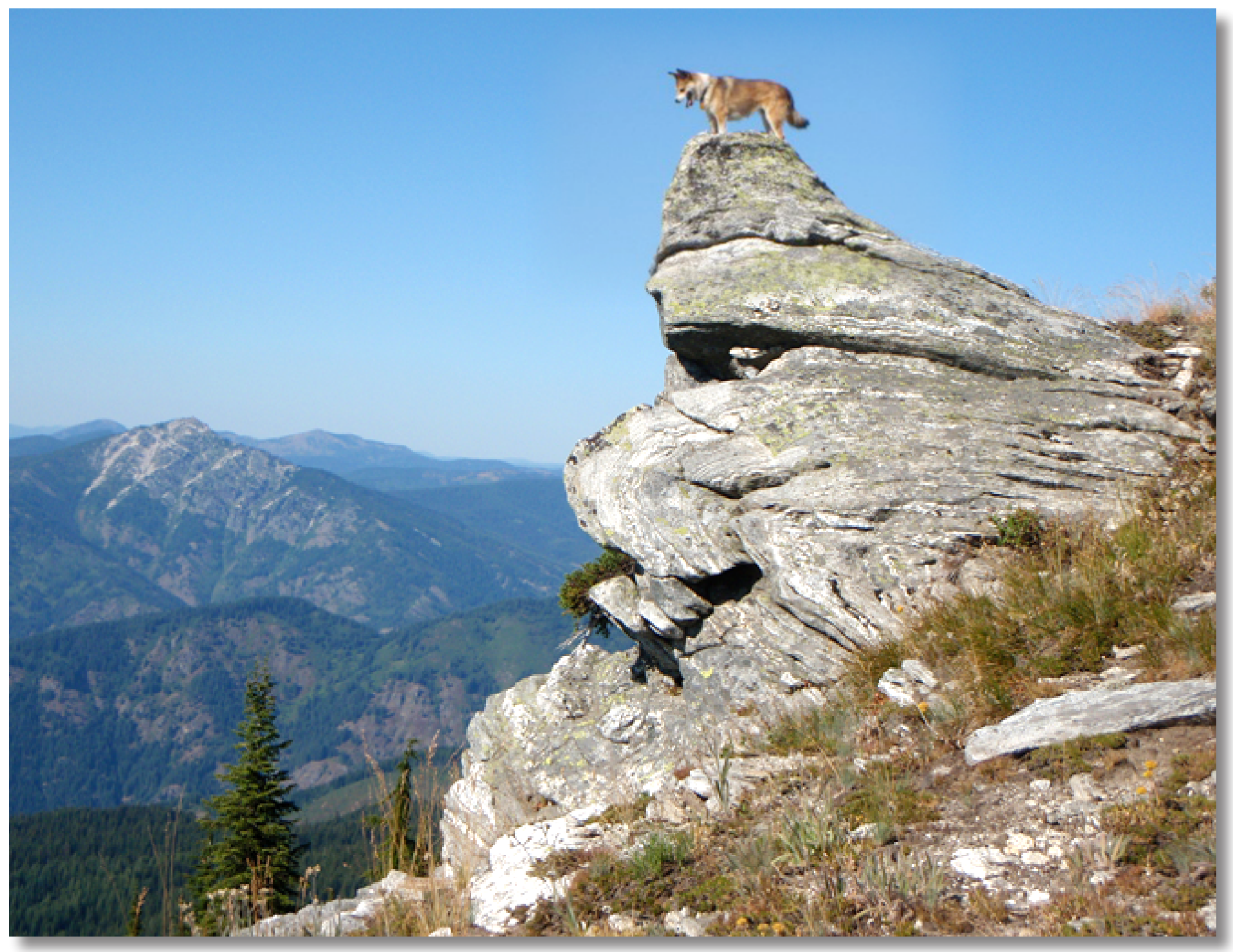

Data Series 898

U.S. Department of the Interior U.S. Geological Survey 
Cover: Isoclinally folded Paleoproterozoic tonalite orthogneiss from newly identified Wallace domain basement, northern Idaho. 


\section{Basement Domain Map of the Conterminous United States and Alaska}

By Karen Lund, S.E. Box, C.S. Holm-Denoma, C.A. San Juan, R.J. Blakely,

R.W. Saltus, E.D. Anderson, and E.H. DeWitt

Data Series 898

U.S. Department of the Interior

U.S. Geological Survey 


\title{
U.S. Department of the Interior SALLY JEWELL, Secretary
}

\section{U.S. Geological Survey Suzette M. Kimball, Acting Director}

\author{
U.S. Geological Survey, Reston, Virginia: 2015
}

For more information on the USGS - the Federal source for science about the Earth, its natural and living resources, natural hazards, and the environment, visit http://www.usgs.gov or call 1-888-ASK-USGS.

For an overview of USGS information products, including maps, imagery, and publications, visit http://www.usgs.gov/pubprod

To order this and other USGS information products, visit http://store.usgs.gov

Any use of trade, firm, or product names is for descriptive purposes only and does not imply endorsement by the U.S. Government.

Although this information product, for the most part, is in the public domain, it also may contain copyrighted materials as noted in the text. Permission to reproduce copyrighted items must be secured from the copyright owner.

Suggested citation:

Lund, Karen, Box, S.E., Holm-Denoma, C.S., San Juan, C.A., Blakely, R.J., Saltus, R.W., Anderson, E.D., and DeWitt, E.H., 2015, Basement domain map of the conterminous United States and Alaska: U.S. Geological Survey Data Series 898, 41 p., http://dx.doi.org/10.3133/ds898.

ISSN 2327-638X (online 


\section{Contents}

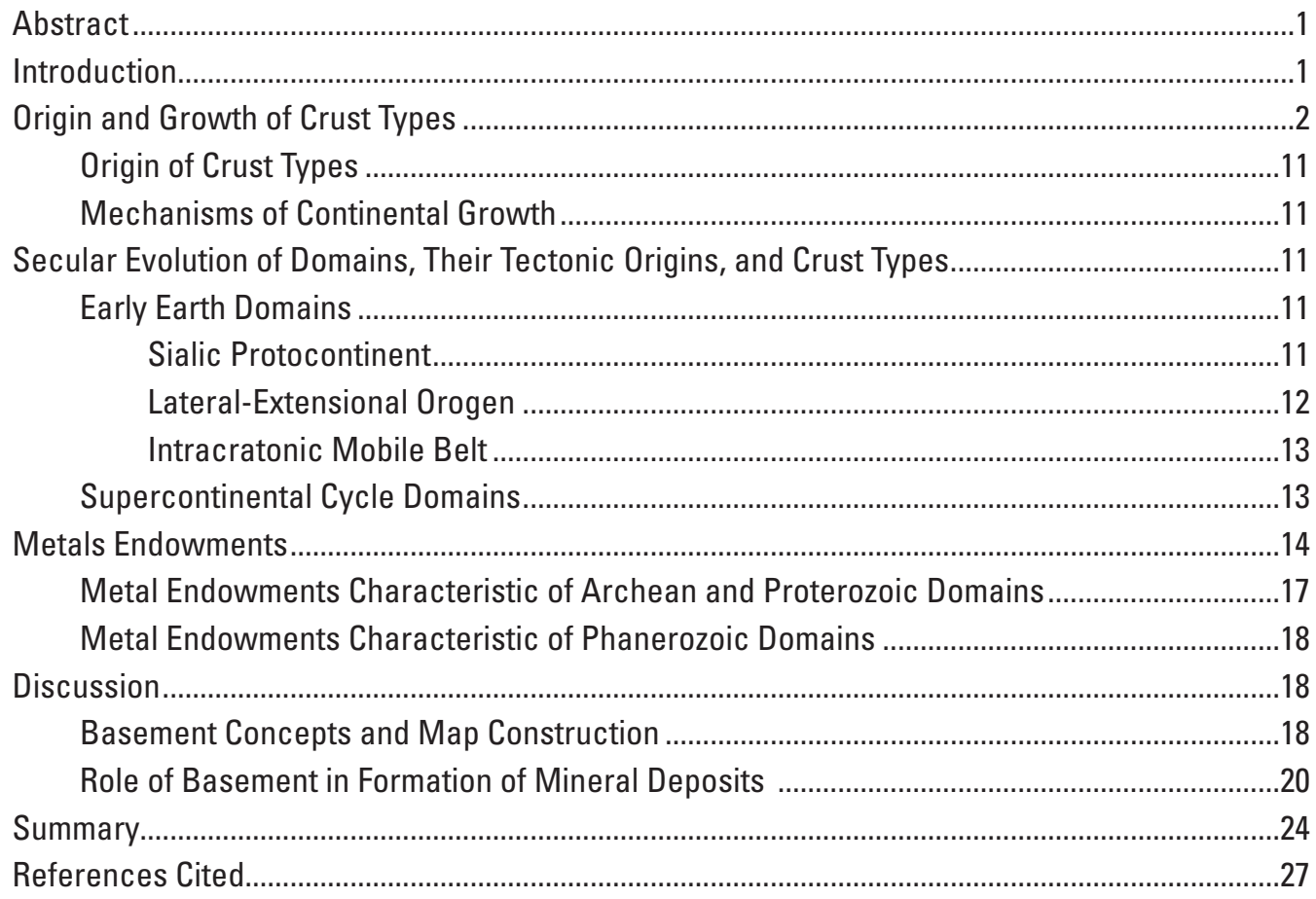

\section{Figures}

1. Map of basement domains of the conterminous United States and Alaska ......................3

2. Index map of basement-domain study regions in the United States ...............................19

3. Map of a time-slice reconstruction of United States basement domains according

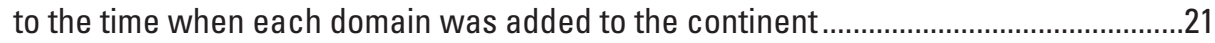

4. Map of basement domains that formed as oceanic arc crust........................................22

5. Map of basement domains that potentially contain geologic environments conducive to formation of porphyry-type mineral deposits ............................................23

6. Map of basement domains overlaid on the North American magnetic map ..................25

7. Map of basement domains showing gold, silver, copper, lead, zinc and other deposits of the conterminous United States and Alaska

\section{Tables}

1. Basement domains of the United States including Alaska ................................................

2. Primary metal endowments of geologic environments that may be present in each crust type interpreted for basement domains in the United States ........................15

3. Status of compilation for each study region of the United States ...................................20 


\title{
Abbreviations Used in This Report
}

\author{
b.y. billion years \\ m.y. million years \\ sedex sedimentary exhalative \\ PGE platinum-group elements \\ REE rare-earth elements \\ USGS U.S. Geological Survey \\ VMS volcanogenic massive sulfide
}




\title{
Basement Domain Map of the Conterminous United States and Alaska
}

\author{
By Karen Lund, S.E. Box, C.S. Holm-Denoma, C.A. San Juan, R.J. Blakely, R.W. Saltus, E.D. Anderson, and \\ E.H. DeWitt
}

\section{Abstract}

The basement-domain map is a compilation of basement domains in the conterminous United States and Alaska designed to be used at 1:5,000,000-scale, particularly as a base layer for national-scale mineral resource assessments. Seventy-seven basement domains are represented as eightythree polygons on the map. The domains are based on interpretations of basement composition, origin, and architecture and developed from a variety of sources. Analysis of previously published basement, lithotectonic, and terrane maps as well as models of planetary development were used to formulate the concept of basement and the methodology of defining domains that spanned the ages of Archean to present but formed through different processes. The preliminary compilations for the study areas utilized these maps, national-scale gravity and aeromagnetic data, published and limited new age and isotopic data, limited new field investigations, and conventional geologic maps. Citation of the relevant source data for compilations and the source and types of original interpretation, as derived from different types of data, are provided in supporting descriptive text and tables.

The tectonic settings for crustal types represented in the basement domains are subdivided into constituent geologic environments and the types of primary metals endowments and deposits in them are documented. The compositions, architecture, and original metals endowments are potentially important to assessments of primary mineral deposits and to the residence and recycling of metals in the crust of the United States portion of the North American continent. The databases can be configured to demonstrate the construction of the United States through time, to identify specific types of crust, or to identify domains potentially containing metal endowments of specific genetic types or endowed with specific metals. The databases can also be configured to illustrate other purposes chosen by users.

\section{Introduction}

The U.S. Geological Survey (USGS) conducts mineral resource assessments at a variety of scales including the national scale. Such studies help ensure adequate mineral supplies and effective stewardship of resources in the future, a critical conclusion of the National Mineral Resource Assessment of 1995 (U.S. Geological Survey National Mineral Resource Assessment Team, see Schruben, 2002). A challenge in assessing mineral resources at the national scale is in employing systematic and uniform approaches based on methodologies and datasets appropriate to that broad scale. For example, national-scale assessments can be frustrated by traditional geologic maps that portray surface geology and widespread cover sequences, that are commonly at more detailed scales, and that are not integrated across political boundaries. Geologic map data are generally inappropriate for identifying broad national-scale mineral endowments and mineralizing processes because they depict the surface geology that commonly conceals the mineralized (or source) rocks and fundamental geologic structures. Research into crustal metal endowments, mineral belts, and mining districts as a means of discriminating mineral resource trends is needed to improve the accuracy and validity of mineral resource models and assessments.

In considering regional crustal processes in relation to ore deposits, Titley (2001), using models of metallogenic provinces (Petrascheck, 1965), explored the concept that basement (defined as

"...The crust of the Earth below sedimentary deposits, extending downward to the Mohorovičić discontinuity. In many places the rocks of the complex are igneous and metamorphic and of Precambrian age, but in some places they are Paleozoic, Mesozoic, or even Cenozoic." (American Geological Institute, 2008, p. 57)) 
composition and architecture are fundamental and critical elements of metallogenesis on a lithospheric scale. Previous USGS mineral resource evaluations do not adequately consider this concept, that basement characteristics (including age and formation processes) influenced the nature or distribution of mineral deposits. Maps of basement domains based on their origin and composition (as opposed to maps limited to the cratonal portions or tectonic maps) of the entire United States remain unavailable. In the context of regional to national resource assessments, this lack of consistent information makes it difficult to incorporate data about the basement.

This study presents an interpretation of the inherent composition, origin, and architecture of the largely unexposed basement underlying the United States in order to produce a national-scale map of basement domains. The map reflects a new approach for investigating mineral deposit systems in the context of whether they formed (1) as part of the primary tectonic setting of basement domains, (2) by processes that thickened the original crust to form continental crust, or (3) in special cases, during multiple reactivations of crust and structures by younger, superposed orogenic events. Although many of the domains portrayed in this map continue into Canada and Mexico, maps showing post-Laurentian basement domains of all ages are not available for those areas. The main goal of this study is to identify domains that compose the United States portion of North American basement for the purpose of evaluating original metal endowments in basement domains at a national scale. The suggested scale for use of the map is $1: 5,000,000$ to match other national datasets used in national assessments by the Mineral Resources Program.

\section{Origin and Growth of Crust Types}

Continental crust (defined as "That type of the Earth's crust which underlies the continents and the continental shelves: it is equivalent to the sial,..." (American Geological Institute, 2008, p. 139)) forms where preexisting mafic crust and overlying supracrustal rocks are modified and thickened during intracrustal tectonic events that produce deposition, deformation, metamorphism, partial melting, underplating, and magmatism (Rudnick and Gao, 2003; Hawkesworth and others, 2010). Continental crust contains basement domains of widely differing origins and evolutionary histories. The most widely recognized basement domains are shield and platform blocks (cratons that have been stable and undisturbed for about 1 billion years (b.y.)) that formed as ancient (generally during Archean and Paleoproterozoic time, possibly extending into the early Mesoproterozoic) orogenic belts. Other basement domains include younger (Mesoproterozoic to the present) blocks that formed in extensional or collisional orogenic belts. In both cases, reworked juvenile igneous crust evolved to continental crust and ultimately to basement (Cawood and others, 2013). The basement domain map presented herein portrays the U.S. basement inclusive of both buried and exposed subaerial continental crust and submerged continental crust on continental shelves (fig. 1).

In general, maps and studies of U.S. basement are restricted to and portray only exposed or inferred Precambrian continental basement (for example, Condie, 1982; Hoffman, 1988; Sims, 1990; Boerboom and others, 2005; Sims and others, 2005; Holm and others, 2007; Whitmeyer and Karlstrom, 2007). It is also common in some contexts to consider crystalline rocks beneath younger cover successions as "basement." The important difference between the basement map presented in this study and most maps of U.S. basement is the concept that relatively young basement domains also formed from original juvenile components. Thus, although commonly more limited in definition, the term "basement" as used herein is not restricted to Precambrian cratons. The concept of metamorphic rocks as basement does not match the definition of basement given previously. By using criteria widely applied to identification either of terranes or of cratons (but not usually combined), the term basement as used herein encompasses the fundamental crustal elements of all ages that compose basement in the conterminous United States and Alaska. Combinations of geochemical, geophysical, geological, and age characteristics (table 1) identify domains as discrete entities. Data table 1 illustrates the variety of tectonic settings and processes that formed and transformed juvenile rocks into continental basement. 


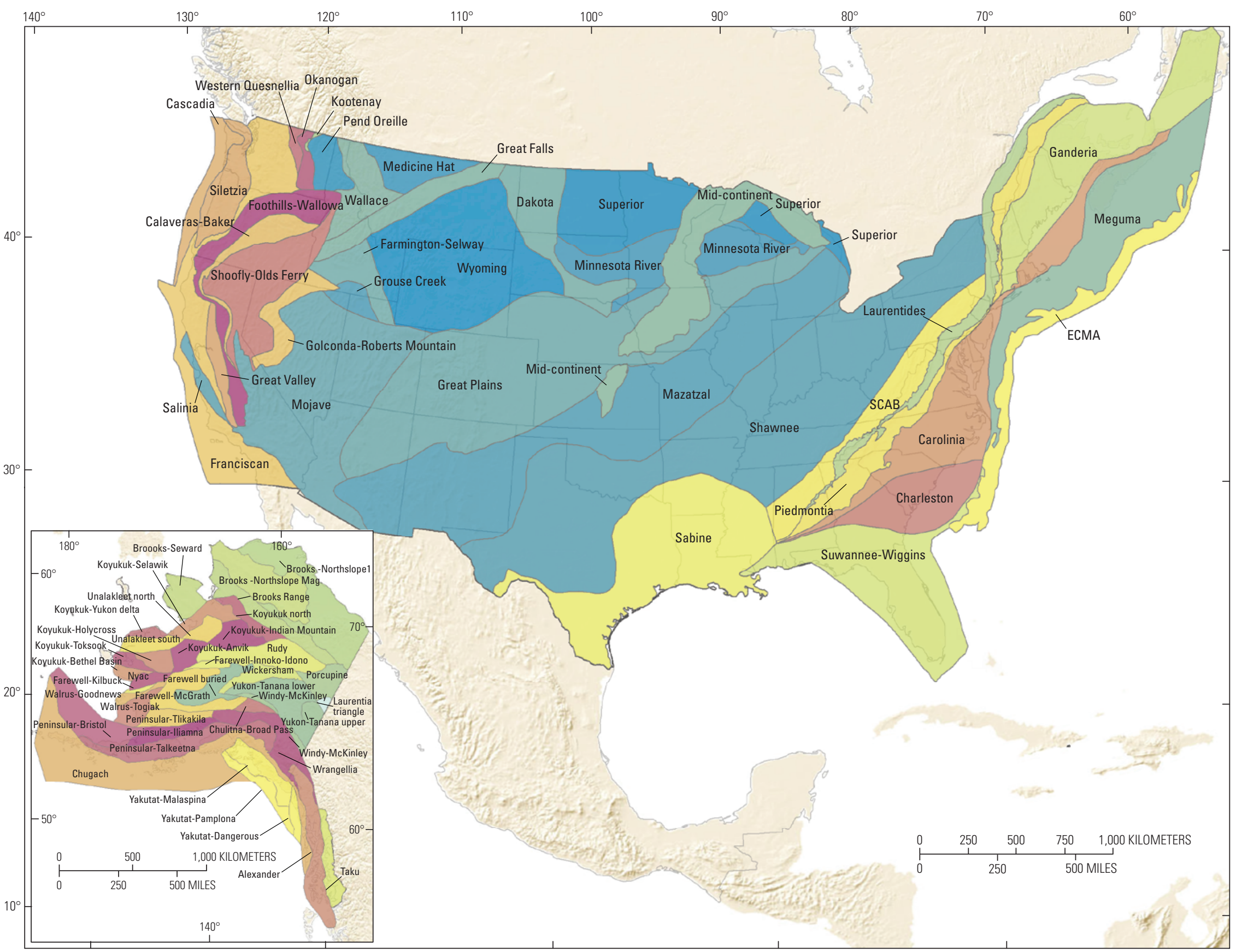

Figure 1. Basement domains of conterminous United States and Alaska. 
Table 1. Basement domains of the United States including Alaska (see fig. 1 for basement domain map).

\begin{tabular}{|c|c|c|c|c|c|c|c|}
\hline Domain_Name & Alternate_Name & Crust_Type & Crust_Formation_Age & Accretion_Type & Accretion_Age & References_ & Notes \\
\hline Minnesota River & -- & $\begin{array}{c}\text { Sialic } \\
\text { protocontinent }\end{array}$ & $3600-3000 \mathrm{Ma}$ & -- & -- & $\begin{array}{l}\text { Sims and others, 1987; Hoff- } \\
\text { man, 1988; Bickford and } \\
\text { others, 2006; Schmitz and } \\
\text { others, } 2006\end{array}$ & Cratonized $\sim 2500$ Ma. \\
\hline Superior & -- & $\begin{array}{c}\text { Sialic } \\
\text { protocontinent }\end{array}$ & $2750-2600 \mathrm{Ma}$ & Collisional & $2.7-2.5 \mathrm{Ga}$ & $\begin{array}{l}\text { Gibbs and others, 1984; Sims } \\
\text { and others, 1987; Hoffman, } \\
\text { 1988; Bickford and others, } \\
\text { 2006; Schmitz and others, } \\
\text { 2006; van Schmus and oth- } \\
\text { ers, } 2007\end{array}$ & $\begin{array}{l}\text { S-vergent collision with } \\
\text { Minnesota River terrane, } \\
\text { Great Lakes tectonic } \\
\text { zone; Cratonized } \\
\sim 2500 \mathrm{Ma} \text {. }\end{array}$ \\
\hline Dakota & Trans-Hudson & $\begin{array}{l}\text { Intracratonic } \\
\text { mobile belt }\end{array}$ & $1848-1750 \mathrm{Ma}$ & -- & -- & $\begin{array}{l}\text { Dutch and Nielson, 1990; Ross } \\
\text { and others, 1991; Sims and } \\
\text { others, 1991; Dahl and oth- } \\
\text { ers, 1999, 2006; Schneider } \\
\text { and others, 2007; McCor- } \\
\text { mick, } 2010\end{array}$ & $\begin{array}{l}\text { Orogenic events } 1.78-1.74 \\
\text { G; post-tectonic magma- } \\
\text { tism and cratonization } \\
\text { at } 1.715 \mathrm{Ga} ; 50-60 \mathrm{~m} . \mathrm{y} \text {. } \\
\text { younger than Trans- } \\
\text { Hudson orogenic events } \\
\text { in Canada. }\end{array}$ \\
\hline Mojave & Mojavia & $\begin{array}{c}\text { Lateral- } \\
\text { extensional orogen }\end{array}$ & $1840 \mathrm{Ma}$ & -- & -- & $\begin{array}{l}\text { Wooden and DeWitt, 1991; } \\
\text { Barth and others, 2000; Due- } \\
\text { bendorfer and others, 2006; } \\
\text { Bickford and Hill, 2007; } \\
\text { Whitmeyer and Karlstrom, } \\
\text { 2007; Mueller and others, } \\
\text { 2011; Nelson and others, } \\
\text { 2011 }\end{array}$ & $\begin{array}{l}\text { Older crustal component } \\
>2.0 ; \text { crustal growth } \\
\text { ages } 1.84,1.78-1.76 \mathrm{Ga} ; \\
\text { includes Elves Chasm } \\
\text { gneiss. }\end{array}$ \\
\hline Great Plains & Yavapai & $\begin{array}{c}\text { Lateral- } \\
\text { extensional orogen }\end{array}$ & $1800-1720 \mathrm{Ma}$ & -- & $1.71-1.68 \mathrm{Ga}$ & $\begin{array}{l}\text { Sims and others, 1987; Carlson, } \\
\text { 2007; Whitmeyer and Karl- } \\
\text { strom, } 2007\end{array}$ & -- \\
\hline Mazatzal & -- & $\begin{array}{c}\text { Lateral- } \\
\text { extensional orogen }\end{array}$ & $1720-1650 \mathrm{Ma}$ & -- & $1.65-1.62 \mathrm{Ga}$ & $\begin{array}{l}\text { Sims and others, 1987; Van } \\
\text { Schmus and others, 2007; } \\
\text { Whitmeyer and Karlstrom, } \\
\text { 2007; Jones and others, } 2013\end{array}$ & -- \\
\hline Mid-continent & Keweenawan & $\begin{array}{l}\text { Intracontinental } \\
\text { rift }\end{array}$ & $1100-1000 \mathrm{Ma}$ & -- & -- & $\begin{array}{l}\text { Van Schmus and Hinze, 1985; } \\
\text { Sims and others, 1987; Van } \\
\text { Schmus and others, } 2007\end{array}$ & -- \\
\hline Wyoming & -- & $\begin{array}{c}\text { Sialic } \\
\text { protocontinent }\end{array}$ & $3500-3200 \mathrm{Ma}$ & -- & -- & $\begin{array}{l}\text { Graff and others, 1982; Tosdal } \\
\text { and others, 2000; Mueller } \\
\text { and others, 2004; Mueller } \\
\text { and Frost, 2006; Foster and } \\
\text { others, 2006; Grauch and } \\
\text { others, 2003; Rodriguez and } \\
\text { Williams, 2008 }\end{array}$ & $\begin{array}{l}\text { Includes } 3.5-3.2 \mathrm{Ga} \text { Mon- } \\
\text { tana metasedimentary } \\
\text { province; } 3.0-2.5 \mathrm{Ga} \\
\text { Beartooth-Bighorn mag- } \\
\text { matic zone, } 2.9 \text { Ga South- } \\
\text { ern accreted terranes; } \\
\text { cratonized 3.0-2.8 Ga. }\end{array}$ \\
\hline
\end{tabular}


Table 1. Basement domains of the United States including Alaska (see fig. 1 for basement domain map).-Continued

\begin{tabular}{|c|c|c|c|c|c|c|c|}
\hline Domain_Name & Alternate_Name & Crust_Type & Crust_Formation_Age & Accretion_Type & Accretion_Age & References_ & Notes \\
\hline Pend Oreille & -- & $\begin{array}{c}\text { Sialic } \\
\text { protocontinent }\end{array}$ & $2670-2650 \mathrm{Ma}$ & -- & -- & $\begin{array}{l}\text { Whitehouse and others, 1992; } \\
\text { Doughty and others, 1998; } \\
\text { Doughty and Chamberlain, } \\
\text { 2008; Lewis and others, } \\
\text { 2011; Brown and others, } \\
2012\end{array}$ & -- \\
\hline Medicine Hat & -- & $\begin{array}{c}\text { Sialic } \\
\text { protocontinent }\end{array}$ & $3300-2600 \mathrm{Ma}$ & -- & -- & $\begin{array}{l}\text { Ross and others, 1991; Boerner } \\
\text { and others, 1998; Buhlmann } \\
\text { and others, 2000; Lemieux } \\
\text { and others, 2000 }\end{array}$ & -- \\
\hline Grouse Creek & -- & $\begin{array}{c}\text { Sialic } \\
\text { protocontinent }\end{array}$ & $2700-2600 \mathrm{Ma}$ & -- & -- & $\begin{array}{l}\text { Cameron, 2010; Strickland and } \\
\text { others, } 2011\end{array}$ & $\begin{array}{l}\text { 2.57 Ga Albion-Grouse } \\
\text { Cr; } 2.674 \mathrm{Ga}, 2.608 \mathrm{Ga} \\
\text { Boulder-Pioneer. }\end{array}$ \\
\hline Farmington-Selway & -- & $\begin{array}{l}\text { Intracratonic } \\
\text { mobile belt }\end{array}$ & $1670 \mathrm{Ma}$ & -- & -- & $\begin{array}{l}\text { Leeman and others, 1985; Wolf } \\
\text { and others, 2005; Foster and } \\
\text { others, 2006; Mueller and } \\
\text { others, 2011; Nelson and } \\
\text { others, 2011; Strickland and } \\
\text { others, 2011 }\end{array}$ & $\begin{array}{l}\text { Possibly } 2 \text { extensional } \\
\text { episodes, } 2.45 \mathrm{Ga} \text { and } \\
1.67 \mathrm{Ga} \text {. }\end{array}$ \\
\hline Wallace & -- & $\begin{array}{l}\text { Intracratonic } \\
\text { mobile belt }\end{array}$ & $1870 \mathrm{Ma}$ & -- & -- & $\begin{array}{l}\text { Armstrong and others, 1977; } \\
\text { Armstrong, 1988; Mueller } \\
\text { and others, 1995; Foster and } \\
\text { Fanning, 1997; Foster and } \\
\text { others, 2006; Doughty and } \\
\text { Chamberlain, 2007; Lewis } \\
\text { and others, 2011 }\end{array}$ & $\begin{array}{l}\text { 1.87 Ga orthogneiss; } \\
1.79 \mathrm{Ga} \text { anorthosite. }\end{array}$ \\
\hline Great Falls & -- & $\begin{array}{l}\text { Intracratonic } \\
\text { mobile belt }\end{array}$ & $1870-1790 \mathrm{Ma}$ & -- & -- & $\begin{array}{l}\text { O’Neill and Lopez, } 1985 ; \\
\text { Lemieux and others, 2000; } \\
\text { Kellogg and others, 2003; } \\
\text { Mueller and others, 2002, } \\
\text { 2005; Vogl and others, 2004 }\end{array}$ & $\begin{array}{l}\text { Orogenic events superposed } \\
1.77-1.71 \mathrm{Ga} \text {. }\end{array}$ \\
\hline Kootenay & -- & Passive margin & $780-500 \mathrm{Ma}$ & Collisional & Jurassic & Colpron and Price, 1995 & $\begin{array}{l}\text { Basement age Neoprotero- } \\
\text { zoic to Early Paleozoic. }\end{array}$ \\
\hline Western Quesnellia & -- & Oceanic arc & $385-175 \mathrm{Ma}$ & Collisional & $170 \mathrm{Ma}$ & $\begin{array}{l}\text { Cheney and others, 1994; } \\
\text { Roback and Walker, 1995; } \\
\text { Dostal and others, 2001; Un- } \\
\text { terschutz and others, 2002 }\end{array}$ & $\begin{array}{l}\text { Continent-marginal island } \\
\text { arc. }\end{array}$ \\
\hline Okanogan & -- & Oceanic arc & $320-250 \mathrm{Ma}$ & Collisional & Mesozoic & Brown and others, 2012 & $\begin{array}{l}\text { Continent-marginal island } \\
\text { arc, Carboniferous- } \\
\text { Permian. }\end{array}$ \\
\hline
\end{tabular}


Table 1. Basement domains of the United States including Alaska (see fig. 1 for basement domain map).—Continued

\begin{tabular}{|c|c|c|c|c|c|c|c|}
\hline Domain_Name & Alternate_Name & Crust_Type & Crust_Formation_Age & Accretion_Type & Accretion_Age & References_ & Notes \\
\hline Shawnee & $\begin{array}{l}\text { Granite-rhyolite, } \\
\text { Llano }\end{array}$ & $\begin{array}{c}\text { Lateral- } \\
\text { extensional orogen }\end{array}$ & $1550-1350 \mathrm{Ma}$ & in situ cratonization & $1.45-1.35$ & $\begin{array}{l}\text { Van Schmus and others, 1996; } \\
\text { McLelland and others, 1993; } \\
\text { Mosher, 1998; Patchett and } \\
\text { Ruiz, } 1989\end{array}$ & $\begin{array}{l}\text { New name for Granite/rhyo- } \\
\text { lite (not in literature). }\end{array}$ \\
\hline SCAB & $\begin{array}{l}\text { Southern and } \\
\text { central Appala- } \\
\text { chian basement }\end{array}$ & $\begin{array}{l}\text { Extensional } \\
\text { accretionary } \\
\text { orogen }\end{array}$ & $1400-1100 \mathrm{Ma}$ & Collisional & $1.1 \mathrm{Ga}$ & $\begin{array}{l}\text { Fischer and others, 2010; } \\
\text { Loewy and others, 2003; } \\
\text { Tohver and others, } 2004\end{array}$ & $\begin{array}{l}\text { Amazonia origin, Mesopro- } \\
\text { terozoic; AL-NY linea- } \\
\text { ment is boundary? }\end{array}$ \\
\hline Laurentides & $\begin{array}{l}\text { Blue Ridge- } \\
\text { Taconide }\end{array}$ & Passive margin & $1250-750 \mathrm{Ma}$ & Collisional & $\begin{array}{l}\text { Late } \\
\text { Ordovician- } \\
\text { Early Silurian }\end{array}$ & $\begin{array}{l}\text { Williams, 1978; Stanley and } \\
\text { Ratcliffe, 1985; Barr and } \\
\text { others, 1998; Hibbard and } \\
\text { others, 2006, } 2010\end{array}$ & $\begin{array}{l}\text { Peri-Gondwana origin, } \\
\text { converted to extensional } \\
\text { accretionary orogen. }\end{array}$ \\
\hline Carolinia & $\begin{array}{c}\text { Carolina and (or) } \\
\text { Raleigh }\end{array}$ & Oceanic arc & $670 \mathrm{Ma}$ & Collisional & Devonian & Hibbard and others, 2006, 2007 & Peri-Gondwana origin. \\
\hline Charleston & Brunswick & Oceanic arc & $1000-542 \mathrm{Ma}$ & Collisional & -- & $\begin{array}{l}\text { Horton and others, } 1989 ; \\
\text { Hatcher and others, } 2010\end{array}$ & $\begin{array}{l}\text { Peri-Gondwana origin, } \\
\text { Neoproterozoic. }\end{array}$ \\
\hline Piedmontia & Peri-Laurentia & $\begin{array}{l}\text { Extensional } \\
\text { accretionary } \\
\text { orogen }\end{array}$ & $1000-416 \mathrm{Ma}$ & Collisional & $\begin{array}{l}\text { Devonian and } \\
\text { younger }\end{array}$ & $\begin{array}{l}\text { Drake, 1989; Horton and oth- } \\
\text { ers, 1989; Horton and others, } \\
\text { 2010; Tull and others, } 2014\end{array}$ & $\begin{array}{l}\text { Laurentian origin, } \\
\text { Neoproterozoic-Silurian } \\
\text { (or younger). }\end{array}$ \\
\hline Ganderia & -- & Passive margin & $630-488 \mathrm{Ma}$ & Collisional & $455-423 \mathrm{Ma}$ & van Staal and others, 2009 & $\begin{array}{l}\text { Neoproterozoic-Silurian (or } \\
\text { younger); Converted to } \\
\text { extensional accretionary } \\
\text { orogen. }\end{array}$ \\
\hline Meguma & -- & Passive margin & $542-472 \mathrm{Ma}$ & Transpressional & Famennian & $\begin{array}{l}\text { Hadley, 1970; van Staal, 2007; } \\
\text { van Staal and others, } 2009\end{array}$ & $\begin{array}{l}\text { Peri-Gondwana origin, } \\
\text { Cambrian-Early Ordovi- } \\
\text { cian; converted to rift } \\
\text { basin. }\end{array}$ \\
\hline ECMA & $\begin{array}{l}\text { East Coast Mag- } \\
\text { netic Anomaly }\end{array}$ & $\begin{array}{l}\text { Large igneous } \\
\text { province }\end{array}$ & $228-176 \mathrm{Ma}$ & Magmatic & -- & Eldholm and others, 2000 & $\begin{array}{l}\text { Late Triassic-Early Jurassic; } \\
\text { crustal boundary based } \\
\text { on geophysical feature. }\end{array}$ \\
\hline Suwannee-Wiggins & Peri-Gondwana & Passive margin & $530-511 \mathrm{Ma}$ & Collisional & $325-300 \mathrm{Ma}$ & $\begin{array}{l}\text { Dallmeyer, 1989; Thomas, } \\
\text { 1991, 2010; Horton and } \\
\text { others, 1991; Heatherington } \\
\text { and others, 2010; Shaulis and } \\
\text { others, } 2012\end{array}$ & $\begin{array}{l}\text { Converted to extensional } \\
\text { accretionary orogen } \\
\text { (forearc basin). }\end{array}$ \\
\hline Sabine & -- & Continental arc & $360-299 \mathrm{Ma}$ & Collisional & $325-309 \mathrm{Ma}$ & $\begin{array}{l}\text { Viele and Thomas, 1989; } \\
\text { Keppie and Ramos, 1999; } \\
\text { Poole and others, } 2005\end{array}$ & $\begin{array}{l}\text { Late Paleozoic Gondwana } \\
\text { microcontinent origin; } \\
\text { includes Sabine volcanic } \\
\text { arc and Yucatan platform. }\end{array}$ \\
\hline
\end{tabular}


Table 1. Basement domains of the United States including Alaska (see fig. 1 for basement domain map).-Continued

\begin{tabular}{|c|c|c|c|c|c|c|c|}
\hline Domain_Name & Alternate_Name & Crust_Type & Crust_Formation_Age & Accretion_Type & Accretion_Age & References_ & Notes \\
\hline Salinia & Salinian block & $\begin{array}{l}\text { Lateral- } \\
\text { extensional orogen }\end{array}$ & $1700 \mathrm{Ma}$ & Strike-slip & $30-0 \mathrm{Ma}$ & $\begin{array}{l}\text { Mattinson and James, 1985; } \\
\text { Barth and others, 2003; } \\
\text { Barbeau and others, 2005 }\end{array}$ & $\begin{array}{l}\text { Fragment of Mohave } \\
\text { domain? }\end{array}$ \\
\hline $\begin{array}{l}\text { Golconda-Roberts } \\
\text { Mountain }\end{array}$ & -- & $\begin{array}{l}\text { Accretionary } \\
\text { wedge }\end{array}$ & $380-350 \mathrm{Ma}$ & Collisional & $350 \mathrm{Ma}$ & $\begin{array}{l}\text { Dickinson, 2006; Wright and } \\
\text { Wyld, 2006; Holm-Denoma } \\
\text { and others, } 2011\end{array}$ & -- \\
\hline Shoofly-Olds Ferry & -- & Oceanic arc & $365-187 \mathrm{Ma}$ & Collisional & $135 \mathrm{Ma}$ & $\begin{array}{l}\text { Edelman and others, 1989; } \\
\text { Snow and Scherer, 2006; } \\
\text { Northrup and others, } 2011\end{array}$ & -- \\
\hline Calaveras-Baker & -- & $\begin{array}{l}\text { Accretionary } \\
\text { wedge }\end{array}$ & $315-215 \mathrm{Ma}$ & Collisional & $135 \mathrm{Ma}$ & $\begin{array}{l}\text { Hacker, 1993; Vallier, 1995; } \\
\text { Dickinson, 2008; Dorsey and } \\
\text { Lamaskin, } 2008\end{array}$ & -- \\
\hline Foothills-Wallowa & -- & Oceanic arc & $280-165 \mathrm{Ma}$ & Collisional & $135 \mathrm{Ma}$ & $\begin{array}{l}\text { Vallier, 1995; Dickinson, 2008; } \\
\text { Dorsey and Lamaskin, 2008; } \\
\text { Ernst and others, } 2008\end{array}$ & $\begin{array}{l}\text { Basement to arc as old as } \\
300 \text { Ma in Klamath Mtns } \\
\text { (Saleeby, 1982). }\end{array}$ \\
\hline Great Valley & -- & Oceanic basin & $175-165 \mathrm{Ma}$ & Magmatic? & $165 \mathrm{Ma}$ & $\begin{array}{l}\text { Cady, 1975; Shervais and } \\
\text { others, } 2005\end{array}$ & -- \\
\hline Franciscan & $\begin{array}{l}\text { Franciscan } \\
\text { equivalents }\end{array}$ & $\begin{array}{l}\text { Accretionary } \\
\text { wedge }\end{array}$ & $165-50 \mathrm{Ma}$ & Underthrusting & $165-50 \mathrm{Ma}$ & $\begin{array}{l}\text { Saleeby, 1982; Ernst, 2011; } \\
\text { Snow and others, 2010; } \\
\text { Wakabayashi and others, } \\
2007\end{array}$ & $\begin{array}{l}\text { In NW CA, accreted rocks } \\
\text { as young as } 15 \mathrm{Ma} \\
\text { (McLaughlin and others, } \\
\text { 1982). }\end{array}$ \\
\hline Siletzia & -- & Oceanic basin & $60-50 \mathrm{Ma}$ & Collisional & $50 \mathrm{Ma}$ & $\begin{array}{l}\text { Babcock and others, 1992; } \\
\text { Parsons and others, } 1999\end{array}$ & $\begin{array}{l}\text { Converted to continen- } \\
\text { tal arc. Some authors } \\
\text { (Schmandt and Hum- } \\
\text { phreys, 2011) suggest } \\
\text { accretion at } 55 \text { Ma. }\end{array}$ \\
\hline Cascadia & -- & $\begin{array}{l}\text { Accretionary } \\
\text { wedge }\end{array}$ & $50-0 \mathrm{Ma}$ & Underthrusting & $50-0 \mathrm{Ma}$ & $\begin{array}{r}\text { Tréhu and others, 1994, 2012; } \\
\text { Stewart and Brandon, } 2004\end{array}$ & $\begin{array}{r}\text { Some authors (Brandon and } \\
\text { others, 1998) suggest on- } \\
\text { set of accretion at } 35 \mathrm{Ma} .\end{array}$ \\
\hline $\begin{array}{l}\text { Farewell-Innoko- } \\
\text { Idono }\end{array}$ & -- & Continental arc & $2600-2100 \mathrm{Ma}$ & Collisional & $135-115 \mathrm{Ma}$ & $\begin{array}{l}\text { Miller and others, 1991; Brad- } \\
\text { ley and others, } 2014\end{array}$ & $\begin{array}{l}\text { Farewell platform, Baltica } \\
\text { origin. }\end{array}$ \\
\hline Farewell-Kilbuck & -- & Continental arc & $2600-2100 \mathrm{Ma}$ & Collisional & $135-115 \mathrm{Ma}$ & $\begin{array}{l}\text { Box and others, 1990; Moll- } \\
\text { Stalcup and others, } 1996\end{array}$ & $\begin{array}{l}\text { Farewell platform, } \\
\text { continent-marginal arc. }\end{array}$ \\
\hline Laurentia triangle & -- & Continental arc & $2450-1850 \mathrm{Ma}$ & Collisional & $1.85 \mathrm{Ga}$ & $\begin{array}{l}\text { Villeneuve and Theriault, 1991; } \\
\text { Gehrels and others, 1999; } \\
\text { Pilkington and Saltus, 2007 }\end{array}$ & Laurentian origin. \\
\hline Brooks-Northslope 1 & -- & Passive margin & $2000 \mathrm{Ma}$ & -- & -- & $\begin{array}{l}\text { Moore and others, 1994, 1997; } \\
\text { Fuis and others, } 2008\end{array}$ & $\begin{array}{l}\text { Brookian crust, Baltica } \\
\text { origin. }\end{array}$ \\
\hline $\begin{array}{l}\text { Brooks-Northslope } \\
\text { Mag }\end{array}$ & -- & Passive margin & $2000 \mathrm{Ma}$ & -- & -- & $\begin{array}{l}\text { Moore and others, 1994; Saltus } \\
\text { and others, } 2006\end{array}$ & $\begin{array}{l}\text { Brookian crust, Baltica } \\
\text { origin. }\end{array}$ \\
\hline
\end{tabular}


Table 1. Basement domains of the United States including Alaska (see fig. 1 for basement domain map).-Continued

\begin{tabular}{|c|c|c|c|c|c|c|c|}
\hline Domain_Name & Alternate_Name & Crust_Type & Crust_Formation_Age & Accretion_Type & Accretion_Age & References & Notes \\
\hline Brooks Range & -- & Passive margin & $2000 \mathrm{Ma}$ & -- & -- & $\begin{array}{l}\text { Moore and others, 1994; Fuis } \\
\text { and others, } 2008 \text { Till and } \\
\text { others, } 2008\end{array}$ & $\begin{array}{l}\text { Brookian crust, Baltica } \\
\text { origin. }\end{array}$ \\
\hline Ruby & -- & Passive margin & $2000 \mathrm{Ma}$ & -- & -- & $\begin{array}{l}\text { Arth and others, 1989a; Roeske } \\
\text { and others, 1995, } 2006\end{array}$ & $\begin{array}{l}\text { Laurentian and Baltica } \\
\text { origins. }\end{array}$ \\
\hline Brooks-Seward & -- & Passive margin & $2000 \mathrm{Ma}$ & -- & -- & $\begin{array}{l}\text { Akinin and others, 2009; } \\
\text { Amato and others, 2009; Till } \\
\text { and others, } 2011\end{array}$ & $\begin{array}{l}\text { Brookian crust, Baltica } \\
\text { origin. }\end{array}$ \\
\hline Farewell-McGrath & -- & Passive margin & $2000 \mathrm{Ma}$ & -- & -- & $\begin{array}{l}\text { McClelland and others, 1999; } \\
\text { Bradley and others, } 2003\end{array}$ & $\begin{array}{l}\text { Farewell platform, Baltica } \\
\text { origin. }\end{array}$ \\
\hline Porcupine & -- & Passive margin & $2000-1000 \mathrm{Ma}$ & -- & $1-2 \mathrm{Ga}$ & $\begin{array}{l}\text { Dover, 1994; Till and others, } \\
\text { 2006; Saltus and Hudson, } \\
2007\end{array}$ & $\begin{array}{l}\text { Laurentian origin, setting, } \\
\text { ages poorly constrained. }\end{array}$ \\
\hline Farewell buried & -- & Back-arc basin & $1000 \mathrm{Ma}$ & -- & -- & $\begin{array}{l}\text { McClelland and others, 1999; } \\
\text { Bradley and others, } 2003\end{array}$ & $\begin{array}{l}\text { Farewell platform, Baltica } \\
\text { origin. }\end{array}$ \\
\hline Yukon-Tanana upper & -- & Passive margin & $700-350 \mathrm{Ma}$ & Collisional/StrSlip & $215 \mathrm{Ma}$ & $\begin{array}{l}\text { Dusel-Bacon and Williams, } \\
\text { 2009; Piercey and Colpron, } \\
2009\end{array}$ & $\begin{array}{l}\text { Continental rise, Laurentian } \\
\text { origin. }\end{array}$ \\
\hline Yukon-Tanana lower & -- & Passive margin & $700-350 \mathrm{Ma}$ & Collisional/StrSlip & $215 \mathrm{Ma}$ & $\begin{array}{l}\text { Hansen and Dusel-Bacon, } \\
\text { 1998; Dusel-Bacon and } \\
\text { Williams, 2009; Piercey and } \\
\text { Colpron, 2009 }\end{array}$ & Continental rise. \\
\hline Wickersham & -- & Passive margin & $700-350 \mathrm{Ma}$ & Collisional/StrSlip & $215 \mathrm{Ma}$ & $\begin{array}{l}\text { Moore and Nokleberg, 1988; } \\
\text { Bradley and others, 2007; } \\
\text { Dusel-Bacon and Williams, } \\
2009\end{array}$ & $\begin{array}{l}\text { Continental rise, Laurentian } \\
\text { origin. }\end{array}$ \\
\hline Alexander & -- & Oceanic arc & $600 \mathrm{Ma}$ & Collisional/StrSlip & $140 \mathrm{Ma}$ & $\begin{array}{l}\text { Samson and others, 1989, 1991; } \\
\text { Gehrels and Berg, } 1994\end{array}$ & Peninsula arc. \\
\hline Taku & -- & Passive margin & $380 \mathrm{Ma}$ & Collisional & $140 \mathrm{Ma}$ & $\begin{array}{r}\text { Rubin and Saleeby, 1991; } \\
\text { Gehrels and Berg, } 1994\end{array}$ & Continental rise. \\
\hline Chulitna-Broad Pass & -- & Oceanic arc & $380 \mathrm{Ma}$ & Collisional/StrSlip & $80 \mathrm{Ma}$ & $\begin{array}{l}\text { Clautice and Newberry, 2006; } \\
\text { Gilman and others, 2009; } \\
\text { Hampton and others, } 2009\end{array}$ & Peninsula arc. \\
\hline Peninsular-Iliamna & -- & Oceanic arc & $310 \mathrm{Ma}$ & Collisional & $80 \mathrm{Ma}$ & $\begin{array}{l}\text { Reed and Lanphere, 1973; } \\
\text { Detterman and others, 1996; } \\
\text { Bacon and others, } 2012\end{array}$ & Peninsula arc. \\
\hline Wrangellia & -- & Oceanic arc & $310 \mathrm{Ma}$ & Collisional & $80 \mathrm{Ma}$ & $\begin{array}{l}\text { Aleinikoff and others, 1988; } \\
\text { Glen and others, 2007; } \\
\text { Greene and others, } 2010\end{array}$ & Peninsula arc. \\
\hline
\end{tabular}


Table 1. Basement domains of the United States including Alaska (see fig. 1 for basement domain map).-Continued

\begin{tabular}{|c|c|c|c|c|c|c|c|}
\hline Domain_Name & Alternate_Name & Crust_Type & Crust_Formation_Age & Accretion_Type & Accretion_Age & References_ & Notes \\
\hline Walrus-Goodnews & -- & $\begin{array}{l}\text { Accretionary } \\
\text { wedge }\end{array}$ & $280-135 \mathrm{Ma}$ & Collisional & $135-115 \mathrm{Ma}$ & $\begin{array}{l}\text { Box and others, 1993; Decker } \\
\text { and others, } 1994\end{array}$ & $\begin{array}{l}\text { Forearc fragment, Walrus } \\
\text { arc. }\end{array}$ \\
\hline Windy-McKinley & -- & Passive margin & $275 \mathrm{Ma}$ & Collisional/StrSlip & $100 \mathrm{Ma}$ & $\begin{array}{l}\text { Nokleberg and others, 1994; } \\
\text { Nokleberg and others, 2007; } \\
\text { Hampton and others, } 2009\end{array}$ & $\begin{array}{l}\text { Continental rise, Farewell } \\
\text { platform. }\end{array}$ \\
\hline Walrus-Togiak & -- & Oceanic arc & $225-135 \mathrm{Ma}$ & Collisional & $135-115 \mathrm{Ma}$ & $\begin{array}{l}\text { Box and others, 1993; Decker } \\
\text { and others, 1994; Miller and } \\
\text { others, } 2007\end{array}$ & Walrus arc. \\
\hline Peninsular-Bristol & -- & Oceanic arc & $215-185 \mathrm{Ma}$ & Collisional & $80 \mathrm{Ma}$ & $\begin{array}{l}\text { Marlow and Cooper, 1980; } \\
\text { Cooper and Marlow, } 1983\end{array}$ & Peninsula arc. \\
\hline Peninsular-Talkeetna & -- & Oceanic arc & $215-185 \mathrm{Ma}$ & Collisional & $80 \mathrm{Ma}$ & $\begin{array}{l}\text { Detterman and others, 1996; } \\
\text { Hacker and others, 2008, } \\
\text { 2011; Farris, } 2009\end{array}$ & Peninsula arc. \\
\hline Peninsular-Tlikakila & -- & $\begin{array}{l}\text { Accretionary } \\
\text { wedge }\end{array}$ & $180 \mathrm{Ma}$ & Underthrusting & $80 \mathrm{Ma}$ & $\begin{array}{l}\text { Wallace and others, } 1989 ; \\
\text { Amato and others, } 2007\end{array}$ & $\begin{array}{l}\text { Forearc fragment, Pennin- } \\
\text { sula arc. }\end{array}$ \\
\hline $\begin{array}{l}\text { Koyukuk-Bethel } \\
\text { Basin }\end{array}$ & -- & Oceanic arc & $175-125 \mathrm{Ma}$ & Collisional & $135-115 \mathrm{Ma}$ & $\begin{array}{l}\text { Hoare, 1961; Patton and Box, } \\
\text { 1989; DGGS Staff and oth- } \\
\text { ers, } 1995\end{array}$ & $\begin{array}{l}\text { Koyukuk arc, setting poorly } \\
\text { constrained. }\end{array}$ \\
\hline Koyukuk-Toksook & -- & Oceanic arc & $175-125 \mathrm{Ma}$ & Collisional & $135-115 \mathrm{Ma}$ & $\begin{array}{l}\text { Box and Patton, 1989; Patton } \\
\text { and Box, } 1989\end{array}$ & Koyukuk arc. \\
\hline Koyukuk-Holycross & -- & Oceanic arc & $175-125 \mathrm{Ma}$ & Collisional & $135-115 \mathrm{Ma}$ & $\begin{array}{l}\text { Hoare, 1961; Box and Patton, } \\
\text { 1989; Patton and Box, } 1989\end{array}$ & Koyukuk arc. \\
\hline $\begin{array}{l}\text { Koyukuk-Yukon } \\
\text { delta }\end{array}$ & -- & Oceanic arc & $175-125 \mathrm{Ma}$ & Collisional & $135-115 \mathrm{Ma}$ & $\begin{array}{l}\text { Hoare and Condon, 1962; Box } \\
\text { and Patton, 1989; Patton and } \\
\text { Box, } 1989\end{array}$ & Koyukuk arc. \\
\hline Unalakleet south & -- & Back-arc basin & $175-125 \mathrm{Ma}$ & Collisional & $135-115 \mathrm{Ma}$ & $\begin{array}{l}\text { Patton and Box, 1989; Patton } \\
\text { and Moll-Stalcup, 1996; Pat- } \\
\text { ton and others, } 2009\end{array}$ & Related to Koyukuk arc. \\
\hline Koyukuk-Anvik & -- & Oceanic arc & $175-125 \mathrm{Ma}$ & Collisional & $135-115 \mathrm{Ma}$ & $\begin{array}{l}\text { Box and Patton, 1989; Moll- } \\
\text { Stalcup and Arth, 1989; } \\
\text { Patton and Box, 1989; Patton } \\
\text { and others, } 2009\end{array}$ & Koyukuk arc. \\
\hline Unalakleet north & -- & Back-arc basin & $175-125 \mathrm{Ma}$ & Collisional & $135-115 \mathrm{Ma}$ & $\begin{array}{l}\text { Patton and Box, 1989; Patton } \\
\text { and Moll-Stalcup, 1996; Pat- } \\
\text { ton and others, } 2009\end{array}$ & $\begin{array}{l}\text { Back-arc basin? Koyukuk } \\
\text { arc. }\end{array}$ \\
\hline $\begin{array}{l}\text { Koyukuk-Indian } \\
\text { Mountain }\end{array}$ & -- & Oceanic arc & $175-125 \mathrm{Ma}$ & Collisional & $135-115 \mathrm{Ma}$ & $\begin{array}{l}\text { Arth and others, 1989b; Box } \\
\text { and Patton, 1989; Patton and } \\
\text { Box, 1989; Patton and } \\
\text { others, 2009 }\end{array}$ & Koyukuk arc. \\
\hline
\end{tabular}


Table 1. Basement domains of the United States including Alaska (see fig. 1 for basement domain map).—Continued

\begin{tabular}{|c|c|c|c|c|c|c|c|}
\hline Domain_Name & Alternate_Name & Crust_Type & Crust_Formation_Age & Accretion_Type & Accretion_Age & References_ & Notes \\
\hline Koyukuk-Selawik & -- & Oceanic arc & $175-125 \mathrm{Ma}$ & Collisional & $135-115 \mathrm{Ma}$ & $\begin{array}{l}\text { Arth and others, 1989b; Box } \\
\text { and Patton, 1989; Patton and } \\
\text { Box, 1989; Patton and } \\
\text { others, 2009 }\end{array}$ & Koyukuk arc. \\
\hline Koyukuk north & -- & Oceanic arc & $175-125 \mathrm{Ma}$ & Collisional & $135-115 \mathrm{Ma}$ & $\begin{array}{l}\text { Box and Patton, 1989; Patton } \\
\text { and Box, 1989; Patton and } \\
\text { others, } 2009\end{array}$ & Koyukuk arc. \\
\hline Nyac & -- & Oceanic arc & $170-110 \mathrm{Ma}$ & Collisional & $135-110 \mathrm{Ma}$ & $\begin{array}{l}\text { Box and others, 1993; Decker } \\
\text { and others, 1994; Wenz, } \\
2005\end{array}$ & Walrus arc. \\
\hline Chugach & -- & $\begin{array}{l}\text { Accretionary } \\
\text { wedge }\end{array}$ & 75-0 Ma & Underthrusting & 75-0 Ma & $\begin{array}{l}\text { Plafker and others, 1994; } \\
\text { Amato and Pavlis, 2010; von } \\
\text { Huene and others, } 2012\end{array}$ & $\begin{array}{l}\text { Forearc fragment, Peninsula } \\
\text { arc. }\end{array}$ \\
\hline Yakutat-Pamplona & -- & $\begin{array}{l}\text { Large igneous } \\
\text { province }\end{array}$ & $55 \mathrm{Ma}$ & Collisional/StrSlip & $50-0 \mathrm{Ma}$ & $\begin{array}{l}\text { Plafker and others, 1994; } \\
\text { Worthington and others, } \\
2012\end{array}$ & $\begin{array}{l}\text { Oceanic plateau, Yakutat } \\
\text { block. }\end{array}$ \\
\hline Yakutat-Dangerous & -- & $\begin{array}{l}\text { Large igneous } \\
\text { province }\end{array}$ & $55 \mathrm{Ma}$ & Collisional/StrSlip & $50-0 \mathrm{Ma}$ & $\begin{array}{l}\text { Plafker and others, 1994; } \\
\text { Worthington and others, } \\
2012\end{array}$ & $\begin{array}{l}\text { Oceanic plateau, Yakutat } \\
\text { block. }\end{array}$ \\
\hline Yakutat-Malaspina & -- & $\begin{array}{l}\text { Large igneous } \\
\text { province }\end{array}$ & $55 \mathrm{Ma}$ & Collisional/StrSlip & $50-0 \mathrm{Ma}$ & $\begin{array}{l}\text { Plafker and others, 1994; } \\
\text { Worthington and others, } \\
2012\end{array}$ & $\begin{array}{l}\text { Oceanic plateau, Yakutat } \\
\text { block. }\end{array}$ \\
\hline
\end{tabular}




\section{Origin of Crust Types}

The compositions, original tectonic settings, and basement-forming processes associated with the large Archean and early Proterozoic basement core of the United States (central and southwestern parts of Laurentia) differ in many respects from those prevalent in the later Proterozoic and the Phanerozoic. Cratonization occurred by a variety of "premodern" tectonic processes (that is, ancient tectonic processes may have operated at different geographic or time scales than do more modern processes). Some premodern processes may have been unique to that time period owing to secular evolution of the planet (Pollack, 1986; Dewey, 2007; Petit, 2010; Rollinson, 2010; Van Kranendonk, 2010; Nagel and others, 2012).

By Mesoproterozoic to Neoproterozoic time, prevailing tectonic processes had begun to transition into those consistent with modern (Mesoproterozoic to the present) processes. Late Mesoproterozoic and younger crustal domains in the United States and Alaska were modified and thickened into continental crust but were not cratonized, as were the older domains. Interpreting original tectonic setting is commonly difficult because orogenic activity may have dismembered or incompletely preserved the original associations (that is, accretionary prisms are identified as part of volcanic arc settings but also in some cases as domain fragments). The basement domain map presented here does not portray orogenic events that overprinted basement domains (and their structural, metamorphic, or igneous manifestations), although a tectonic map that portrays those events could be developed as a derivative of this basement domain map.

\section{Mechanisms of Continental Growth}

Modern continents grow-add crust to a continental margin - through three basic accretion processes. A common mechanism is accretion of both exotic and native crustal fragments along consumptive plate boundaries (Condie, 2005; Kearey and others, 2009). The exotic fragments may consist of more primitive crustal fragments, such as seamount, island arc chain, oceanic plateau, and backarc or oceanic basin. Other fragments may be native continental blocks transported and reattached. A second mechanism accretes crust as a consequence of failed rifting and extensional orogenesis within continents. A third, less commonly discussed, extensional process that also results in continental growth involves prolonged slab-rollback (or slab-retreat) processes associated with lateral growth (for example, extensional accretionary orogens, Collins, 2002a,b). In modern examples, this type of continental growth involves complex, short-lived $(\approx 10$ million years (m.y.)), and laterally extensive tectonic switching in the continent-fringing backarc region. It is a consequence of transient slab rollback (relative to the overriding plate) and resultant local rifting and basin inversion in the overriding plate (Betts and Giles, 2006; Gray and others, 2007). The backarc region may evolve into continental crust (Cawood and others, 2011) through as much as 250 m.y. (Collins, 2002b).
The secular evolution of the planet requires that tectonic processes changed during the more than 4 b.y. history of U.S. basement geology. The accretionary processes described in the previous paragraph are those operative in modern tectonism, but these processes had ancient tectonic analogues that also formed basement. In particular, Archean greenstone belt domains were formed by tectonic processes that are not presently operative (Adam and others, 2012). High heat production (radiogenic heat and residual heat from planet formation and amalgamation processes) during the Archean depleted incompatible elements of the mantle during formation of early oceanic crust (Rollinson, 2010; Van Kranendonk, 2010; Polat, 2012). Hybrid or protomodern tectonic processes may have been responsible for formation of other domains such as late Paleoproterozoic to Mesoproterozoic domains.

Relations among domains are complicated where basement that formed in one setting becomes a fundamental element reworked in a second crust-building event (for instance, passive marginal basin was converted to extensional accretionary orogen in the Piedmont domain of the Appalachian region (Barr and others, 1998; van Staal and others, 1998; Tull and others, 2014). A second complication involves native fragments that originally formed as part of proto-North America but translated or rifted and subsequently reattached; both the eastern and western Laurentian Phanerozoic margins grew by means of this style of tectonic amalgamation. Determining the geospatial origin of the affected fragments is correspondingly difficult (Wyld and Wright, 2001; Hibbard and others, 2006; Colpron and others, 2007; Lund and others, 2008). Another structural complication, difficult to portray on a two-dimensional map, is the obduction of one crustal domain over another.

\section{Secular Evolution of Domains, Their Tectonic Origins, and Crust Types}

\section{Early Earth Domains}

Much about early Earth crust-forming processes is controversial, but most agree that the operative tectonic processes differed in important ways from those involved in "modern" late Proterozoic and Phanerozoic basement formation (Armstrong, 1991; Hamilton 1998; Shervais, 2006; Hawkesworth and others, 2010; Rollinson, 2010; Van Kranendonk, 2010; Adam and others, 2012; Polat, 2012). The number and scale of early sialic protocontinental masses is also controversial because of their poor preservation and extremely limited exposure (Bleeker, 2003; Condie, 2007).

\section{Sialic Protocontinent}

The oldest rocks in the Archean sialic protocontinental domains are ultramafic (such as high-magnesium komatiite) and mafic volcanic rocks that reflect extraction of large 
volumes of magma from the mantle at oceanic ridges, as a consequence of high heat production in the mantle (Rollinson, 2010; Van Kranendonk, 2010; Polat, 2012). Closely associated supracrustal volcanogenic turbiditic sedimentary rocks were deposited in associated ocean basins. Other mafic to felsic volcanic rocks, plutonic rocks, and related volcanogenic sedimentary rocks may have formed in proto-oceanic arcs (Van Kranendonk, 2010; Polat, 2012). High temperature gradients prevailing in the Archean [?] crust resulted in greenstone- and eclogite-facies metamorphism and the partial melting of mafic to ultramafic crust; early-style subduction caused greenschist to amphibolite facies metamorphism (Polat, 2012). Both types of metamorphism promoted partial melting of metamorphosed basalt, producing voluminous felsic batholiths of the tonalite-trondhjemite-granite association (Jahn and others, 1981; Adam and others, 2012; Nagel and others, 2012). Metamorphosed volcanic and volcanogenic sedimentary belts were in-folded between domal-shaped tonalite-trondhjemite-granite-association batholiths, thereby preserving metamorphic rocks in large synformal hinges separated by the batholithic antiformal hinges and resulting in characteristic granite-greenstone belt complexes.

The presence of Paleoproterozoic lower crustal layers below Archean upper crust in some domains suggests that early-formed crust underwent thermal evolution and thickened to form cratons during Paleoproterozoic modification along the margins of Archean sialic protocontinents (Pollack, 1986; Gorman and others, 2002). Premodern cratonization generated roots or cratonal "keels" about twice as thick as those in younger continental crust, which caused Archean domains to resist younger deformation and structural reactivation and destruction by plate tectonic processes (that is, subduction) in later Proterozoic and Phanerozoic supercontinent cycles (Nance and others, 2014).

\section{Lateral-Extensional Orogen}

Broad Paleoproterozoic to early Mesoproterozoic orogenic belts (or orogens; see Sims and Peterman, 1986; Hoffman, 1988; Van Schmus and others, 1996; Whitmeyer and Karlstrom, 2007) abut the southern margins of the Archean domains (fig. 1). They are generally envisioned as having been amalgamated in processes similar to those active in modern accretionary collages (for example, Bowring and Karlstrom, 1990; Karlstrom and Humphreys, 1998; see references in Whitmeyer and Karlstrom, 2007). However, the products of magmatism and deformation, which would correspond to collisional tectonism along the margins of adjacent Archean sialic protocontinental domains, are extremely limited or absent (Bickford and Hill, 2007; Jones and others, 2009, 2013; see references in Whitmeyer and Karlstrom, 2007).

Rocks in the Paleoproterozoic and early Mesoproterozoic domains (fig. 1) contain much primitive basalt and bimodal volcanic rocks that are characterized by distinctive intraoceanic arc and backarc affinities and thick turbidite fan successions (Hill and Bickford, 2001; Whitmeyer and
Karlstrom, 2007; DeWitt and others, 2010a); locally this suite contains primitive mafic and ultramafic complexes, dikes, and sheeted dike complexes (Dann, 1997). Isotopic and geochemical data indicate that these rocks formed as juvenile ensimatic crust in ocean and backarc basins (Aleinikoff and others, 1993; Hill and Bickford, 2001; Holm and others, 2005; Duebendorfer and others, 2006; DeWitt and others, 2010a). Temporally associated, large, calc-alkaline batholiths intruded these rocks (table 1) (Duebendorfer and others, 2001; Karlstrom and Williams, 2006). These primitive-basin Paleoproterozoic domains in Laurentia initiated synchronously with a period of widespread rifting of Archean sialic protocontinental domains (Bleeker, 2003).

Rock unit ages, deformational and metamorphic events (Van Schmus and others, 1993), and mantle derivation of magmas, as suggested by $\mathrm{Nd}$ and $\mathrm{Pb}$ isotope data (Wooden and DeWitt, 1991; Aleinikoff and others, 1993; Wooden and others, 2012), document the progressive crustal growth (accretion) outward from the Archean domains. These domains are underlain by extensional-style oceanic (hot and seismically low-velocity) upper mantle (Gorman and others, 2002). Temporally overlapping magmatism and deformation in each Proterozoic domain were ongoing for 100-150 m.y. These relations suggest domain formation involving prolonged outward growth accompanied by multiple, short-lived orogenic events that alternated between (1) rift and slab rollback forming transient ocean-crust-floored and backarc rift basins and (2) flat or shallow subduction or slab polarity flip that formed narrow transient orogenic belts. The lateral-extensional belts (orogens) manifest as narrow, short-lived fragments, oceanic arcs, accreting arc, and forearc interleaved with oceanic (and backarc) basin rocks in relations similar to those of assemblages in modern extensional accretionary orogens (see Collins, 2002b; Gray and others, 2002).

Other evidence pointing to this origin is that, although juvenile igneous rocks underlie large portions of the lateralextensional domains, rocks in the domains also commonly contain evidence of older crust on the basis of isotopic inheritance signatures. This isotopic inheritance is explained by the presence of extended older crust (Archean or mixed Archean and earlier Paleoproterozoic), rafted blocks of older crust within intervening juvenile crust, or incorporation of detritus shed from the older (Archean or mixed) provenance onto the younger (Paleoproterozoic) oceanic crust (for example, Duebendorfer and others, 2006; Bickford and Hill, 2007; Egan and Meredith, 2007; Whitmeyer and Karlstrom, 2007; Nelson and others, 2011).

Evolution from juvenile crust to basement was accomplished by transient and intermittent deformation (Harris and others, 1987; Condie, 1992; Duebendorfer and others, 2001) and granulite facies metamorphism (Condie, 1992; Hill and Bickford, 2001; Duebendorfer and others, 2001; Whitmeyer and Karlstrom, 2007). The metamorphism was related in part to large-volume magmatism (Williams and Karlstrom, 1996; Dumond and others, 2007) that accompanied high heat flow in thinned (extended) crust. 
Ferroan (A-type) granite and rhyolite are particularly abundant in these late Paleoproterozoic and especially Mesoproterozoic domains (Anderson, 1983; Anderson and Morrison, 1992; Shaw and others, 2005; Goodge and Vervoort, 2006; DeWitt and others, 2010b). These magmas were likely generated during crustal extension, when the rigid juvenile crust of these lateral-extensional orogens was sufficiently thinned to allow upwelling of asthenosphere, decompression melting or underplating, high heat flow, and partial melting of the crust (Jones and others, 2010; Dall'Agnol and others, 2012). The prevalence of these ferroan granitic magmas at this time probably reflects the transition in the Earth's ongoing structural evolution to modern plate tectonic processes (Dall'Agnol and others, 2012). Locally thick supracrustal quartzite successions of about the same age as the ferroan igneous events provide the timing of depositional basins and relatively short-lived crustal extension, possibly caused by slab rollback events (Jones and others, 2009). Such late-tectonic magmatic and supracrustal basin formation events may both contribute to basement formation (Gray and others, 2007).

\section{Intracratonic Mobile Belt}

Narrow Paleoproterozoic intracratonic mobile belt domains between Archean sialic protocontinent domains are composed of tholeiitic and komatiitic basalt, possible komatiite, volcanogenic turbidite deposits, island arc successions, and plutonic rocks (O'Neill and Lopez, 1985; Mueller and others, 2002; Egger and others, 2003; Burger, 2004; Corrigan and others, 2005; White and others, 2005; Foster and others, 2006; Mueller and Frost, 2006; Strickland and others, 2011; Gaschnig and others, 2013). Using modern collisional tectonic models, these domains were previously interpreted as (1) intracratonic deformation zones (Boerner and others, 1998; Buhlmann, and others, 2000; Lemieux and others, 2000), (2) active collision zones between Archean continents (Ross, 2002; Corrigan and others, 2005; Hajnal and others, 2005), or (3) crust (of unspecified origin) captured during collisions between Archean sialic protocontinents (Mueller and others, 2002, 2004, 2005; Harms and others, 2004). Isotopic data indicate that a large proportion of rocks in the intracratonic mobile belt domains originated as complex intracontinental rift basins floored by juvenile crust (Baird and others, 1996; Dahl and others, 1999, 2006). Supporting a rift origin are age and isotopic evidence (table 1; Ross and others, 1991; Doughty and others, 1998; Dahl and others, 1999, 2006; Lewis and others, 2011), which suggest that Archean sialic protocontinental domains separated by the mobile-belt rocks originated as part of a single crustal domain (the Wyoming and Superior domains, Dahl and others, 1999, 2006). The intracratonic mobile belts are all broadly synchronous (Harms and others, 2004) and possibly initiated by mantle-plume activity (as suggested for the Dakota domain; Schmitz and others, 2006) that caused breakup of Archean sialic protocontinental domains. Other dating studies (table 1, FarmingtonSelway domain) have produced complex age data suggesting development scenarios that involved (1) supracrustal rocks with Archean provenance (Nelson and others, 2011) atop rocks that underwent Paleoproterozoic extension and magmatism or (2) incomplete rifting of older basement (Mueller and others, 2011). Within the juvenile rift-related rocks, restricted zones of island arc magmatic rocks and evidence of shortlived structural and metamorphic events parallel the domain axes (McCormick, 2010); these orogenic zones are interpreted as late or terminating phases of domain development (Mueller and others, 2005; Dahl and others, 2006; Schneider and others, 2007). Age data (table 1) suggest relatively rapid tectonic switching from rifting to slab failure and tectonic reversal whereby juvenile crust was consumed in transitory local, zone-parallel subduction zones. Seismic imaging has not revealed remnant, subducted slabs or extensive magmatic arcs related to collisional accretion (Buhlmann and others, 2000; Lemieux and others, 2000), thus corroborating ideas that these intracratonic mobile belt domains represent an extensive, early type of failed rift system in which short-lived incipient subduction systems formed restricted island arcs and collisions without major consumptive margins.

Intracontinental mobile belts are particularly associated with younger extensional reactivation and accompanying rapidly subsiding, deep sedimentary basins, especially the Mesoproterozoic Belt and Lemhi basins in the Wallace and Great Falls domains, the Paleozoic-Mesozoic Williston basin in the Dakota domain (Baird and others, 1996; McCormick, 2010), the Neoproterozoic Uinta Mountain basin in the FarmingtonSelway domain (Dehler and others, 2005), and the Mesoproterozoic basin overlapping the boundary between the Yavapai and Mazatzal domains (fig. 1; Daniel and others, 2013). As is true for the lateral-extensional domains, Mesoproterozoic extension and deposition were followed by ferroan magmatism (Wallace domain; Evans and Zartman, 1990; Ferguson and others, 2007; Lewis and others, 2007) and orogeny including magmatism (Picuris orogeny; Daniel and others, 2013), both of which may have contributed to cratonization. Relative to adjacent Archean sialic protocontinental domains, the Paleoproterozoic intracratonic mobile-belt domains, which were reactivated by Mesoproterozoic extension, subsequently produced more voluminous Phanerozoic crustal magma (Foster and others, 2006) and contain more abundant overprinted mineral deposits (Klein and Sims, 2007).

\section{Supercontinental Cycle Domains}

During planetary evolution, tectonic settings transitioned from ancient earth types to the present settings. Modern, subduction-related tectonic processes became dominant by the middle part of the Mesoproterozoic, reflecting maturity of Earth crustal structure, heat flow, and convective recycling (Cawood and others, 2006; Dewey, 2007; Van Kranendonk, 2010). These processes operated in similar time scales and at similar geographic scales to those associated with modern plate tectonics (for example, extensive stable island-arc systems or marginal rift basins were established). Descriptions 
of these well-defined settings and discussions of the geologic processes responsible for their formation are widely available (for example, Condie, 2005; Kearey and others, 2009).

Recurrent processes involved supercontinent assembly and breakup. One result was repeated collisions between the older domains, whereby domains were added around the cratonal core. Nonnative domains were added as well as the translation and reattachment of some native domains (Fischer and others, 2010). Another result of the supercontinent cycles was an early stage of intracontinental rifting that added crust before ultimately forming a failed rift (midcontinent rift, table 1; Van Schmus and Hinze, 1985).

In supercontinent breakup, rift margins formed on both sides of Laurentia (the complex cratonic core of North America). Resultant passive margins promoted formation of large marginal-rift sedimentary basins on transitional crust (Hoffman, 1991). Along the eastern margin, repeated Phanerozoic arc-continent and continent-continent collisions added allochthonous and para-autochthonous domains, including exotic juvenile and older continental fragments (table 1). Along the western margin (shown on fig. 1 as defined by the 0.706 initial Sr isopleth; Armstrong and others, 1977; Armstrong, 1988; Carlson and others, 1991; Fleck and Gunn, 1991; Tosdal and others, 2000; Fleck and Criss, 2007; Benford and others, 2010), prolonged sediment deposition in passivemargin domains were punctuated by late Paleozoic contraction causing these domains to be thrust faulted over and accreted onto the edge of Laurentia. Subsequent development of a prolonged consumptive plate boundary resulted in orthogonal and tranpressional collisions, complicated by secondary marginparallel translation that formed the accretionary collage of Alaska and western Cordillera of the conterminous United States. These domains originated in a variety of tectonic settings, including both allochthonous oceanic domains and those native to North America (mostly in the form of slivers of passive-margin domains, table 1).

\section{Metals Endowments}

The rocks associated with each original tectonic setting and geologic environment (table 1) are potentially enriched in specific groups of metals that originated as particular mineral deposit types (table 2). Such enrichments represent primary accumulations that formed synchronously with and as part of the same processes responsible for the development of the hosting basement ("constructional phase deposits" of Groves and Bierlein, 2007). Potential metal accumulations, depicted as potential original endowments in the context of geologic environments of particular tectonic settings (table 2), are expressed by the full array of grades from subeconomic to economic. Thus, although potentially buried or not sufficiently concentrated to constitute ore deposits, these original metal endowments may be deposits in their own right or may have been available for remobilization by younger magmatic and (or) hydrothermal systems to form mineral deposits by a broad variety of younger mineralizing processes.

The origins of some Archean-Paleoproterozoic (to possibly early Mesoproterozoic) host rocks and the mineral deposits or metal endowments contained therein are relatively unusual because of similarly unusual geotectonic processes that operated during early planetary evolution (De Wit and Thiart, 2005; Groves and Bierlein, 2007; Cawood and Hawkesworth, 2012). In addition, the formation of Archean to early Mesoproterozoic host rock is more closely related to formation of their original metal endowments than is true for many younger basement-domain types. These close relations among older basement-domain types and original metal endowments largely reflect the thick roots and resultant buoyancy of the domains, which render ancient continental crust relatively resistant to younger deformation and destruction. Consequently, there have been fewer opportunities to remobilize and concentrate original metal accumulations in the Archean and Paleoproterozoic domains (Groves and Bierlein, 2007). 
Table 2. Primary metal endowments of geologic environments that may be present in each crust type interpreted for basement domains in the United States.

\begin{tabular}{|c|c|c|c|}
\hline Crust_Type & Geologic_Environments & Primary_Metals_Deposits & References \\
\hline \multirow[t]{4}{*}{ Sialic protocontinent } & \multirow[t]{2}{*}{ Oceanic ridge } & Magmatic $\mathrm{Ni}-\mathrm{Cu} \pm \mathrm{PGE}$ & $\begin{array}{l}\text { Cox and Singer, 1986; Arndt and } \\
\text { others, } 2005 .\end{array}$ \\
\hline & & Stratiform $\mathrm{Ni}-\mathrm{Cu}-\mathrm{Cr} \pm \mathrm{PGE}$ & Schultz and others, 2010. \\
\hline & Early oceanic arc & Porphyry Cu-Mo & $\begin{array}{l}\text { John and others, 2010; Taylor and } \\
\text { others, 2012. }\end{array}$ \\
\hline & Supracrustal basin & Banded $\mathrm{Fe}$ formation & $\begin{array}{l}\text { Cox and Singer, 1986; Bekker and } \\
\text { others, } 2010 .\end{array}$ \\
\hline \multirow[t]{6}{*}{ Lateral-extensional orogen } & \multirow[t]{4}{*}{ Spreading ridge } & Stratiform $\mathrm{Ni}-\mathrm{Cu}-\mathrm{Cr} \pm \mathrm{PGE}$ & $\begin{array}{l}\text { Cox and Singer, 1986; Schulte and } \\
\text { others, } 2012 .\end{array}$ \\
\hline & & Podiform $\mathrm{Cr}$ & $\begin{array}{l}\text { Cox and Singer, 1986; Cawthorn } \\
\text { and others, 2005; Mosier and } \\
\text { others, } 2012 .\end{array}$ \\
\hline & & Magmatic Ni-Cu \pm PGE & $\begin{array}{l}\text { Arndt and others, 2005; Schultz and } \\
\text { others, } 2010 .\end{array}$ \\
\hline & & $\mathrm{Cu}-\mathrm{Zn}-\mathrm{Pb} \pm \mathrm{Au}-\mathrm{Ag} \mathrm{VMS}$ & $\begin{array}{l}\text { DeMatties, 1994; Franklin and } \\
\text { others, 2005; Mosier and others, } \\
\text { 2009; Shanks and Thurston, } 2012 .\end{array}$ \\
\hline & Intraoceanic arc & $\mathrm{Cu}-\mathrm{Zn}-\mathrm{Pb} \pm \mathrm{Au}-\mathrm{Ag} \mathrm{VMS}$ & $\begin{array}{l}\text { Hannington and others, 2005; } \\
\text { Mosier and others, 2009; Shanks } \\
\text { and Thurston, } 2012 .\end{array}$ \\
\hline & Late-stage A-type igneous activity & $\begin{array}{l}\text { Magmatic } \mathrm{Sn} \pm \mathrm{Nb}-\mathrm{Ta}-\mathrm{Zr}-\mathrm{F} \text { and } \\
\quad \mathrm{Zr}, \mathrm{Y} \pm \mathrm{REE}\end{array}$ & Dall'Agnol and others, 2012. \\
\hline \multirow[t]{6}{*}{ Intracratonic mobile belt } & \multirow[t]{3}{*}{ Spreading ridge } & Magmatic Ni-Cu \pm PGE & Schultz and others, 2010. \\
\hline & & Podiform Cr & $\begin{array}{l}\text { Singer and others, 1986; Cawthorn } \\
\text { and others, 2005; Mosier and } \\
\text { others, 2012. }\end{array}$ \\
\hline & & $\mathrm{Zn}-\mathrm{Pb}-\mathrm{Cu}-\mathrm{Ag} \mathrm{VMS}$ & $\begin{array}{l}\text { Mosier and others, 2009; Shanks } \\
\text { and Thurston, } 2012 .\end{array}$ \\
\hline & \multirow[t]{2}{*}{ Intraoceanic arc } & $\mathrm{Cu}-\mathrm{Zn}-\mathrm{Pb} \pm \mathrm{Au}-\mathrm{Ag} \mathrm{VMS}$ & $\begin{array}{l}\text { Franklin and others, 2005; } \\
\text { Hannington and others, 2005; } \\
\text { Mosier and others, 2009; Shanks } \\
\text { and Thurston, } 2012 \text {. }\end{array}$ \\
\hline & & Porphyry Cu-Mo & $\begin{array}{l}\text { John and others, 2010; Taylor and } \\
\text { others, 2012. }\end{array}$ \\
\hline & Late-stage A-type igneous activity & $\begin{array}{l}\text { Magmatic } \mathrm{Sn} \pm \mathrm{Nb}-\mathrm{Ta}-\mathrm{Zr}-\mathrm{F} \text { and } \\
\mathrm{Zr}, \mathrm{Y} \pm \mathrm{REE}\end{array}$ & Dall'Agnol and others, 2012. \\
\hline Intracontinental rift & $\begin{array}{l}\text { Layered mafic intrusion and ring } \\
\text { complexes }\end{array}$ & Magmatic Ni-Cu \pm PGE & $\begin{array}{l}\text { Nicholson and others, 1992; Schultz } \\
\text { and others, } 2010 .\end{array}$ \\
\hline
\end{tabular}


Table 2. Primary metal endowments of geologic environments that may be present in each crust type interpreted for basement domains in the United States.-Continued

\begin{tabular}{|c|c|c|c|}
\hline Crust_Type & Geologic_Environments & Primary_Metals_Deposits & References \\
\hline & & $\mathrm{Fe}-\mathrm{Ti} \pm \mathrm{V}$ & $\begin{array}{l}\text { Nicholson and others, 1992; Schultz } \\
\text { and others, } 2010 .\end{array}$ \\
\hline & $\begin{array}{l}\text { Mafic volcanic and supracrustal } \\
\text { basin }\end{array}$ & Native $\mathrm{Cu}$ & $\begin{array}{l}\text { Nicholson and others, 1992; Schultz } \\
\text { and others, } 2010 .\end{array}$ \\
\hline & & $\mathrm{Zn}-\mathrm{Pb}-\mathrm{Cu}-\mathrm{Ag} \mathrm{VMS}$ & Shanks and Thurston, 2012. \\
\hline Passive margin & Marginal basin (miogeocline) & $\begin{array}{l}\mathrm{Zn}-\mathrm{Pb}-\mathrm{Ag} \pm \mathrm{Au} \text { and barite sedi- } \\
\text { mentary exhalative (sedex) }\end{array}$ & $\begin{array}{l}\text { Albers, 1983; Dawson and others, } \\
\text { 1991; Goodfellow and others, } \\
\text { 1993; Leach and others, 2005; } \\
\text { Lund, } 2008 .\end{array}$ \\
\hline Continental arc & Forearc wedge & Podiform $\mathrm{Cr}$ & $\begin{array}{l}\text { Singer and others, 1986; Cawthorn } \\
\text { and others, 2005; Mosier and } \\
\text { others, } 2012 \text {. }\end{array}$ \\
\hline \multirow[t]{3}{*}{ Oceanic arc } & Magmatic arc & Porphyry $\mathrm{Cu}-\mathrm{Au}$ & $\begin{array}{l}\text { Berger and others, 2008; John and } \\
\text { others, } 2010 .\end{array}$ \\
\hline & & $\mathrm{Au}-\mathrm{Cu}$ epithermal & $\begin{array}{l}\text { Groves and others, 1998; Simmons } \\
\text { and others, } 2005 .\end{array}$ \\
\hline & & $\mathrm{Cu}-\mathrm{Zn}-\mathrm{Pb} \pm \mathrm{Au}-\mathrm{Ag} \mathrm{VMS}$ & $\begin{array}{l}\text { Hannington and others, 2005; } \\
\text { Mosier and others, 2009; Shanks } \\
\text { and Thurston, } 2012 \text {. }\end{array}$ \\
\hline Oceanic basin & Black smoker and brine pool & $\mathrm{Cu}-\mathrm{Zn}$ and $\mathrm{Au}$-base metal VMS & $\begin{array}{l}\text { Galley and others, 2007; Schultz } \\
\text { and others, 2010; Shanks and } \\
\text { Thurston, 2012. }\end{array}$ \\
\hline \multirow[t]{3}{*}{ Accretionary wedge } & Oceanic crust & $\mathrm{Cu}-\mathrm{Zn}-\mathrm{Pb} \pm \mathrm{Au}-\mathrm{Ag} \mathrm{VMS}$ & $\begin{array}{l}\text { Alt and others, 1998; Shanks and } \\
\text { Thurston, } 2012 .\end{array}$ \\
\hline & & Podiform $\mathrm{Cr}$ & $\begin{array}{l}\text { Cawthorn and others, 2005; Mosier } \\
\text { and others, } 2012 .\end{array}$ \\
\hline & Trench & MVT (forearc) & Leach and others, 2005. \\
\hline \multirow[t]{2}{*}{ Back-arc basin } & Spreading ridge & $\mathrm{Cu}-\mathrm{Zn}-\mathrm{Pb} \pm \mathrm{Au}-\mathrm{Ag}-\mathrm{Ba} \mathrm{VMS}$ & Shanks and Thurston, 2012. \\
\hline & Supracrustal basin & $\mathrm{Cu} \pm \mathrm{Pb}-\mathrm{Zn}$ sedex & $\begin{array}{l}\text { Leach and others, 2005; Goodfel- } \\
\text { low and Lydon, } 2007 .\end{array}$ \\
\hline \multirow[t]{2}{*}{ Extensional accretionary orogen } & Spreading ridge & Stratiform Ni-Cu-Cr $\pm \mathrm{PGE}$ & $\begin{array}{l}\text { Cox and Singer, 1986; Schulte and } \\
\text { others, } 2012 .\end{array}$ \\
\hline & & Podiform $\mathrm{Cr}$ & $\begin{array}{l}\text { Cox and Singer, 1986; Cawthorn } \\
\text { and others, 2005; Mosier and } \\
\text { others, 2012. }\end{array}$ \\
\hline
\end{tabular}


Table 2. Primary metal endowments of geologic environments that may be present in each crust type interpreted for basement domains in the United States.-Continued

\begin{tabular}{|c|c|c|c|}
\hline Crust_Type & Geologic_Environments & Primary_Metals_Deposits & References \\
\hline & & Magmatic $\mathrm{Ni}-\mathrm{Cu} \pm \mathrm{PGE}$ & $\begin{array}{l}\text { Arndt and others, 2005; Schultz and } \\
\text { others, } 2010 .\end{array}$ \\
\hline & Intraoceanic arc & $\mathrm{Cu}-\mathrm{Zn}-\mathrm{Pb} \pm \mathrm{Au}-\mathrm{Ag} \mathrm{VMS}$ & $\begin{array}{l}\text { Hannington and others, 2005; } \\
\text { Mosier and others, 2009; Shanks } \\
\text { and Thurston, } 2012 .\end{array}$ \\
\hline & & Porphyry $\mathrm{Cu}-\mathrm{Mo}$ & $\begin{array}{l}\text { John and others, 2010; Taylor and } \\
\text { others, } 2012 .\end{array}$ \\
\hline & Supracrustal basin & Banded Fe formation & $\begin{array}{l}\text { Cox and Singer, 1986; Bekker and } \\
\text { others, } 2012 .\end{array}$ \\
\hline & & $\mathrm{Fe}-\mathrm{Ti} \pm \mathrm{V}$ & $\begin{array}{l}\text { Nicholson and others, 1992; Schultz } \\
\text { and others, } 2010 .\end{array}$ \\
\hline & & U-REE-Nb & $\begin{array}{l}\text { Nicholson and others, 1992; Schultz } \\
\text { and others, } 2010 .\end{array}$ \\
\hline & & Stratiform $\mathrm{Ni}-\mathrm{Cu}-\mathrm{Cr} \pm \mathrm{PGE}$ & $\begin{array}{l}\text { Cox and Singer, 1986; Schulte and } \\
\text { others, } 2012 .\end{array}$ \\
\hline
\end{tabular}

\section{Metal Endowments Characteristic of Archean and Proterozoic Domains}

In Archean sialic protocontinental and Proterozoic lateral-extensional and intracratonic mobile-belt domains, mafic and ultramafic rocks, which originated as oceanic crust in greenstone complexes, host magmatic Ni-Cu-PGE (platinum group elements) sulfide deposits and enrichments (Schulz and others, 2010). Types of banded iron formation deposits are closely related to submarine volcanic rocks or to passivemargin sedimentary successions that reflect associations with greenstone complexes, to variable atmospheric conditions and, in part, to ancient changes in oceanic and atmospheric oxidation conditions (Cox and Singer, 1986; Bekker and others, 2010). Diamond deposits formed in deep roots beneath the cratons in Archean sialic protocontinental domains, where mantle plumes melted metasomatized mantle at the base of thickened subcontinental lithospheric mantle (Cox and Singer, 1986; Hausel, 1998; Piranjo, 2000; Gurney and others, 2005; Wyman and others, 2008).

Several other metal endowments or deposit types hosted in Archean-Paleoproterozoic greenstone belts have analogues in Phanerozoic rocks (table 2). However, variations among these similar types of modern and ancient mineral-deposit (endowment) types were probably the result of different conditions or processes that prevailed early in the Earth's evolution - such as higher ancient heat flow, variation in distribution of elements in the crust, redox conditions, and rates of tectonic processes. Volcanogenic massive sulfide deposits are associated with volcanic and volcanogenic rocks in the Archean-Paleoproterozoic greenstone complexes (Mosier and others, 2009; Shanks and Thurston, 2012). In the presence of rift-related hydrothermal activity, podiform $\mathrm{Cr}$ deposits formed within mafic volcanic rocks derived from ocean-spreading centers (Singer and others, 1986; Mosier and others, 2012). Stratiform Ni-Cu-Cr-PGE deposits formed in layered mafic-ultramafic intrusions (Cox and Singer, 1986; Schulte and others, 2012) associated with greenstone complexes. Mafic to felsic rocks of marine intraarc volcanic origin may contain early porphyry $\mathrm{Cu}-\mathrm{Mo}$ deposits, although most Precambrian volcanic systems are eroded to levels well below the crustal levels at which this type of deposit forms (John and others, 2010; Taylor and others, 2012).

In Paleoproterozoic and early Mesoproterozoic domains, large genetically related Sn deposits formed in late-stage ferroan granitic magmatic systems, some of which also contain $\mathrm{Nb}$, Ta, Y-REE (rare earth elements), $\mathrm{Zr}$, and $\mathrm{F}$ resources (Dall'Agnol and others, 2012). Iron oxide-copper-gold (IOCG) deposits are spatially related to these granitic rocks, but the magmas may have been a crustal preparatory event that rendered the crust conducive to the formation of this deposit type. Most IOCG mineralizing systems were driven by much younger hydrothermal activity during which the metals were introduced (Groves and others, 2010). 


\section{Metal Endowments Characteristic of Phanerozoic Domains}

Metal endowments characteristic of late Mesoproterozoic through Phanerozoic domains relate directly to modern plate tectonic processes and settings (table 2). However, because tectonic events after formation of these endowments affected most of these domains, many mineral deposits are related to superposed orogenic events. Most of these orogenic mineral deposits were ultimately derived from and superimposed on original metal accumulations that originated with the basement domain. Accordingly, establishing the basement-forming tectonic settings (basement constructional stages) can guide identification of original metal endowments and subsequent metal assemblages (Groves and Bierlein, 2007). In comparison to the Archean and Paleoproterozoic domains, metal accumulations of Phanerozoic domains, which formed at shallow crustal levels in their original tectonic settings, may be preserved because more limited erosion acted on these younger domains.

Intracontinental rift and continental rift-margin domains, which augmented Laurentia during protracted late Mesoproterozoic and Neoproterozoic to early Paleozoic events, generated large sedimentary basins and miogeoclines, respectively, built on transitional rifted crust. Both of these environments hosted notable sedimentary exhalative (sedex-type) mineral endowments and deposits (Albers, 1983; Dawson and others, 1991; Goodfellow and others, 1993; Leach and others, 2005; Goodfellow and Lydon, 2007; Lund, 2008). Volcanism associated with intracontinental rifting also produced volcanogenic massive sulfide (commonly called VMS) and native $\mathrm{Cu}$ deposits in basin settings (Nicholson and others, 1992; Shanks and Thurston, 2012). Layered mafic rocks and ring complexes associated with intracontinental rifting were enriched in magmatic Ni-Cu \pm PGE as well as Re-Ti and U-REE-Nb (Nicholson and others, 1992; Schulz and others, 2010).

Diverse oceanic-origin domains, which were accreted to Laurentia as part of the accretionary collages of the western Cordillera and Alaska as well as to the collisional orogenic belts associated with the Appalachian and Gulf regions (table 1), constitute a wide variety of geologic environments potentially enriched in metals (table 2). Oceanic crust found in accretionary wedge, backarc, and ocean basin domains are potential hosts for $\mathrm{Cu}-\mathrm{Zn}-\mathrm{Pb} \pm \mathrm{Au}-\mathrm{Ag}$ volcanogenic massive sulfide, podiform $\mathrm{Cr}$, and $\mathrm{Ni}-\mathrm{Cu} \pm \mathrm{PGE}$ endowments (increased abundance to form deposits) (Ben-Avraham and Nur, 1983; Arndt and others, 2005; Cawthorn and others, 2005; Galley and others, 2007; Schulz and others, 2010; Mosier and others, 2012; Shanks and Thurston, 2012). Domains containing forearc trench fragments may also have genetic associations with Mississippi Valley-type (known as MVT) $\mathrm{Pb}-\mathrm{Zn}$ deposits (Leach and others, 2005). Magmatic-arc domains, such as island arcs and Andean-type continental margin arcs, are conducive to the formation of porphyry (Berger and others, 2008; John and others, 2010) and volcanogenic massive-sulfide-style deposits or endowments (Alt and others, 1998; Shanks and Thurston, 2012). Relatively less deeply eroded, young magmatic-arc domains may also contain $\mathrm{Au}-\mathrm{Cu}$ epithermal-type metal deposits or endowments (Simmons and others, 2005).

\section{Discussion}

\section{Basement Concepts and Map Construction}

Construction of the North American continent is conventionally viewed as a series of four general, temporally discrete assembly phases. In that context, the first two phases formed Archean cratons and Paleoproterozoic orogens (parts of Laurentia) and, subsequently, the last two formed orogenic belts that were added during supercontinent assembly and breakup and as the Cordilleran and Alaskan accretionary collages. These two sets of phases are each conceptualized differently and not portrayed on the same maps (see Hoffman, 1988, 1997; Silberling and others, 1992; Hibbard and others, 2006; Whitmeyer and Karlstrom, 2007; Sims and others, 2008). Whereas tectonic origins are generally of primary importance to basement maps of the midcontinent and southwestern U.S. cratonal regions (the Laurentian parts), the concept of basement or its origin is little considered for other parts of the conterminous United States. The orogenic belts added during supercontinent assembly and breakup (Grenville and Appalachian orogens), including multiple tectonic overprints and displacements, are commonly mapped according to lithotectonic units and zones of orogenic overprint (Hibbard and others, 2006) rather than as discrete terranes or basement types (that is, the distinction between Grenville deformation front and the Grenville-age basement of Fischer and others, 2010). The Cordilleran collage is most commonly treated using terrane concepts in which the tectonic setting of supracrustal rocks, but not necessarily of the basement, is highlighted (Silberling and others, 1992). The differences in geology and tectonic evolution among the broad regions of the United States are striking and important, and the differing approaches generally used to define their origins do not promote ready comparison of basement compositions or of potential metal endowments.

The basement domain map presented herein was constructed region by region (fig. 2) by using a unifying approach for the constituent elements of basement domains underlying the entire United States. Despite differences relative to the amounts of original data as compared with compilation of published interpretations used to synthesize each regional map (table 3), the map was constructed to characterize the original tectonic setting in which each domain developed and according to the general scheme described in this report. Thus, the basement of each identified domain (table 1) has a characteristic geochemical signature, structural fabric, paleotectonic and paleoclimatic history, and potential inherent metal endowment 


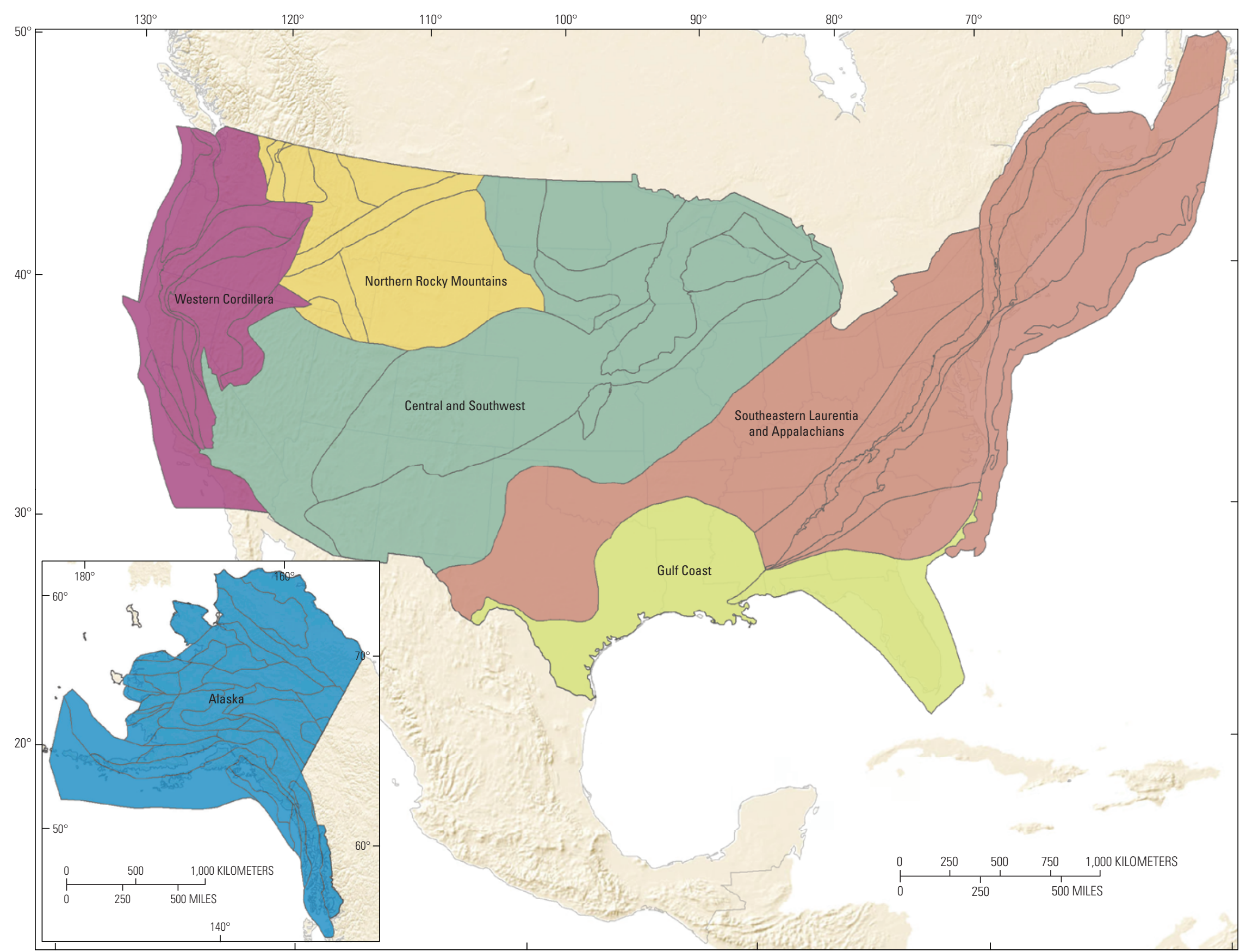

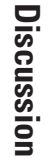

Figure 2. Basement-domain study regions of the United States. 
Table 3. Status of compilation for each study region of the United States (see fig. 2 for regions).

\begin{tabular}{lcc}
\hline \multicolumn{1}{c}{ Study_Region_Name } & Status & Source \\
\hline Alaska & $\begin{array}{c}\text { Domain interpretations revised based on published } \\
\text { geochronologic, geologic, and geophysical data }\end{array}$ & Box, S., and Saltus, R. \\
Western Cordillera & $\begin{array}{c}\text { Domain interpretations revised based on published } \\
\text { geochronologic, geologic, and geophysical data }\end{array}$ & Box, S., and Blakely, R. \\
Northern Rocky Mountains & $\begin{array}{l}\text { Preliminary domain interpretations based on new and } \\
\text { ongoing geochronologic and geologic studies and on }\end{array}$ & Lund, K., and Anderson, E. \\
& $\begin{array}{l}\text { geophysical maps } \\
\text { Boundaries from compilation. Revised interpretations of } \\
\text { original tectonic setting }\end{array}$ & Lund, K.; See references, table 1 \\
Southeastern Laurentia and Appalachians & $\begin{array}{l}\text { Revised interpretations based on ongoing geochronologic } \\
\text { and geologic studies and compilation }\end{array}$ & Holm-Denoma, C. \\
Gulf Coast & Compilation & Lund, K.; See references, table 1 \\
\hline
\end{tabular}

(table 2). Synthesizing the characteristics by using these data resulted in a relatively finite number of original tectonic settings. Because basement of all ages was classified in terms of original tectonic setting, the settings and their characteristics are common across the various regions of the country despite different subsequent tectonic histories. This approach also highlights the changes in tectonic setting and mineral endowment produced during planetary evolution.

The relatively uniform approach to characterization of U.S. basement domains led to a reevaluation of tectonic settings and aspects of continental growth for some domains. The map of interpreted basement domains (fig. 1) depicts extension-dominant orogenesis (lateral-extensional orogen and intracontinental mobile belt) as a principal contributor to crustforming processes and possibly the predominant process that formed basement in the Paleoproterozoic. More than a third of the area of the conterminous United States seems to have originated by this efficient process of intermittent and transient switching between (1) relative slab retreat (extensional accretion) causing basin formation and (2) relative convergence, which caused arc or forearc development and collision-related thickening (arc accretion). Thus, substantial continental growth was accomplished by generating magmatic and sedimentary additions in an overall extensional setting (Collins, 2002b; Giles and others, 2002; Gray and others, 2007). Interpretation of slab rollback models proposed to explain accretion of continental crust (Bickford and Hill, 2007; Jones, Connelly, and others, 2009; Jones, Barnes, and others, 2013) represents a departure from the generally accepted "assembly" scenario, which depends on collisional accretion as the predominant process of growth during the Paleoproterozoic (for example, Whitmeyer and Karlstrom, 2007).

Another benefit of the approach used to create the new basement domain map is that its development in a geographic information system framework allows conceptualization of broadly different derivative products. For instance, the database can be used to create time slices for the tectonic construction of the U.S. parts of North American basement (fig. 3), either for all regions together or with basement in the conterminous United States and Alaska being considered separately. Reconstructions of this sort can be tailored to the needs of the user-for example, to show age groupings of basement domains (fig. 1), selected crust types (fig. 4), or selected metal endowment types (fig. 5).

\section{Role of Basement in Formation of Mineral Deposits}

North American mineral deposits formed through many prolonged crust-building and orogenic cycles of continental amalgamation and breakup as well as of accretionary collages that reactivated structures, thickened crust, and recycled crustal materials. The tectonic settings and mechanisms of formation of orogenic and postorogenic mineral deposits are the subject of many decades of research (see for example, Hedenquist and others, 2005). What is less well defined is the source of the metals and, in the larger sense, which metals were derived from subducted slabs, the mantle, or innate endowments in continental basement (for example, Petrascheck, 1969).

Studies of regional mineral deposit distribution relative to the origin of enveloping terranes and cratonal fragments (that is, basement domains) have documented contrasting metal accumulations in crust of different origins (Albers, 1983; Tooker, 1983). Original tectonic setting is clearly important to metal accumulations in some supracrustal rock associations (Leach and others, 2005; Goodfellow and Lydon, 2007; Lund, 2008). Similarly, early Earth processes that produced unique chemical compositions of Archean-Paleoproterozoic crust and genetically related underlying metasomatized mantle are thought to be instrumental in the occurrence of specific types of younger metal deposits (Groves and Bierlein, 2007). Consequently, the composition and original metal endowments of individual basement domains and of different geologic settings within domains (table 2, fig. 5) may be important progenitors 


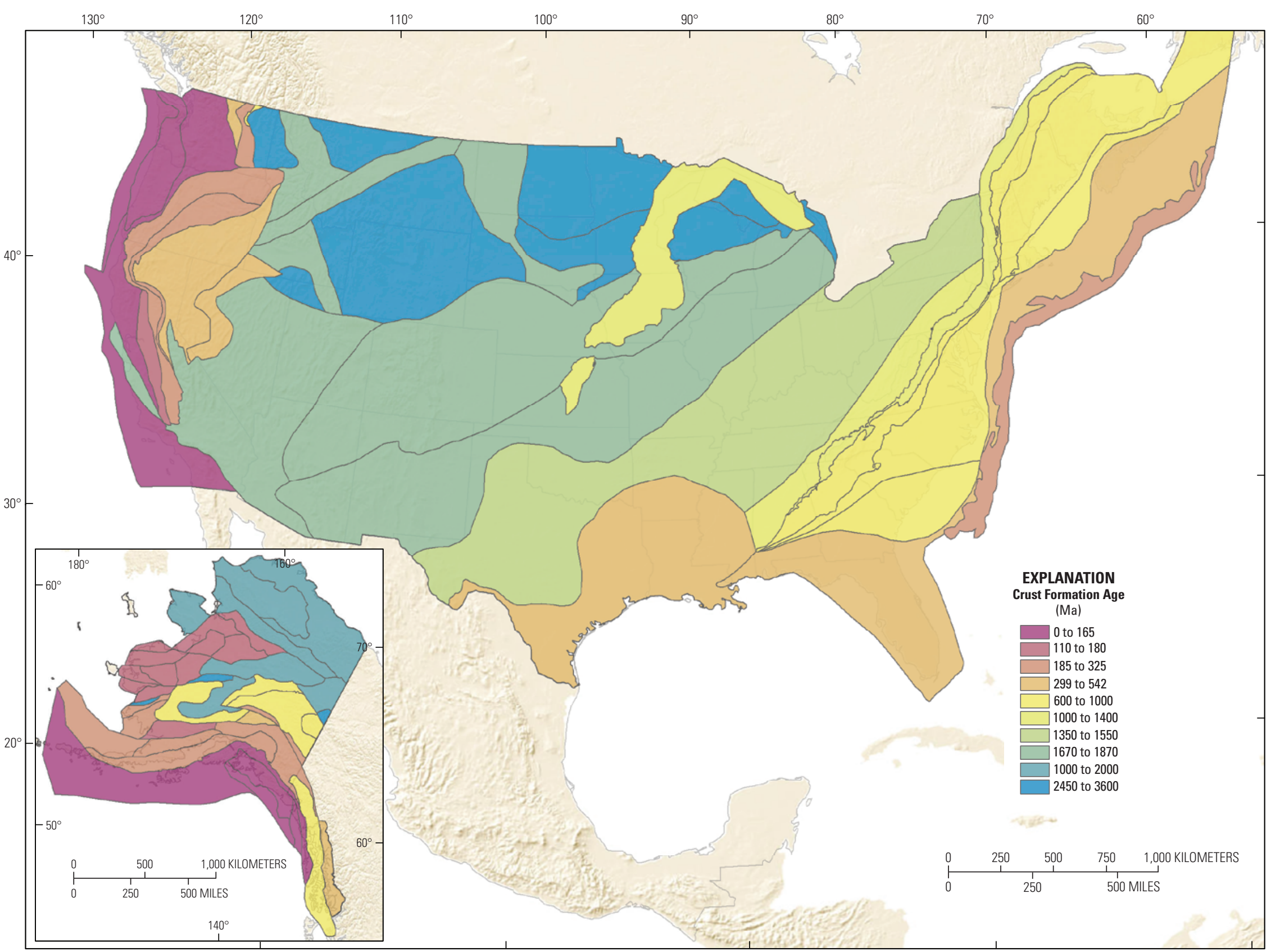

Figure 3. Time-slice reconstruction of United States basement domains according to the time when each domain was added to the continent, as determined by crust formation age or accretion age (see table 1). 


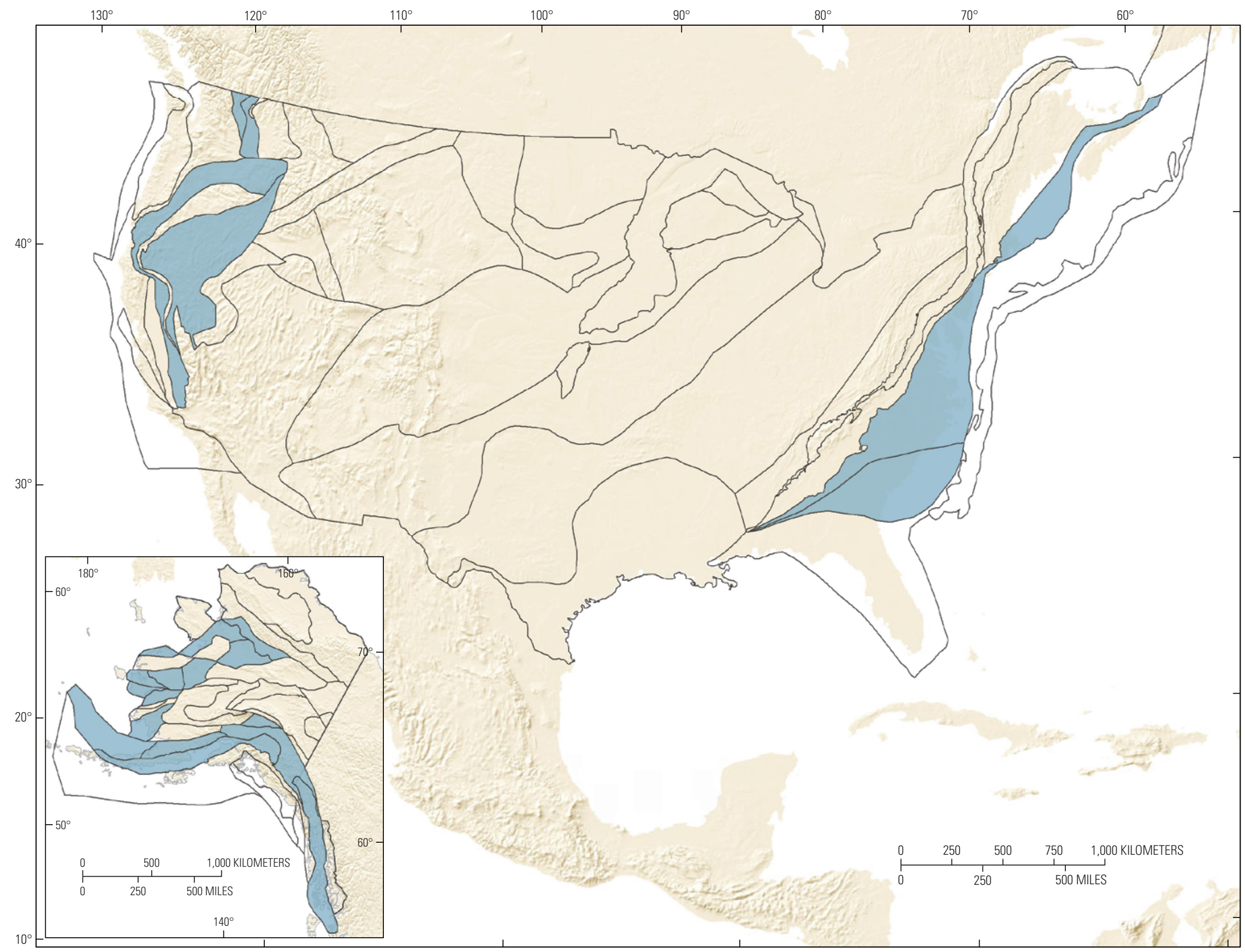

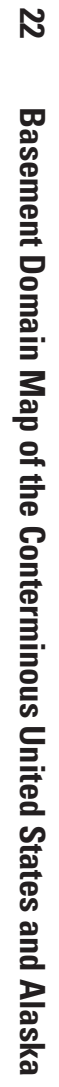

Figure 4. Sample map product of basement domains that formed as oceanic arc crust. 


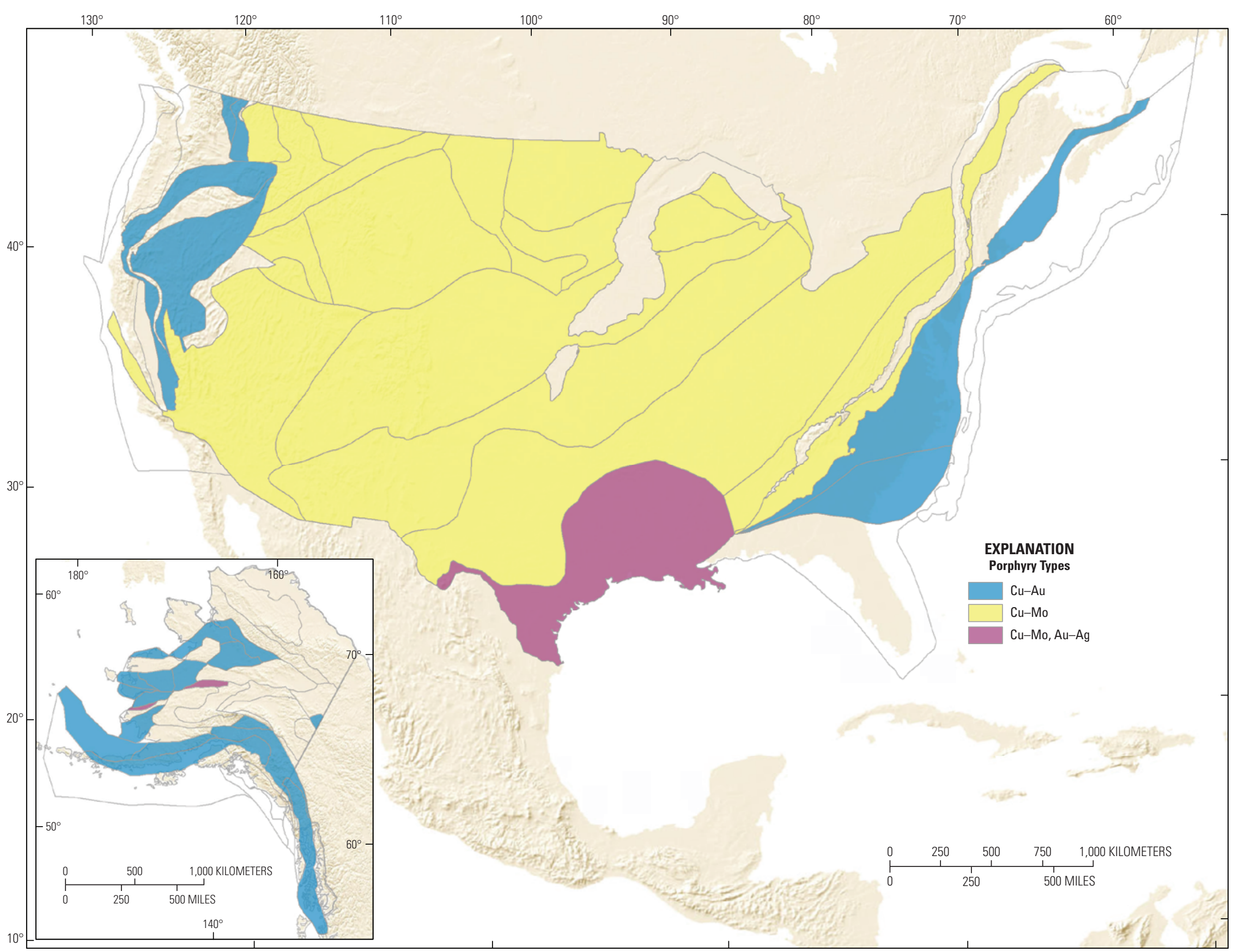

Figure 5. Sample map product of basement domains that potentially contain geologic environments conducive to formation of porphyry-type mineral deposits. 
of mineral deposits by contributing metals from original basement endowments (Titley, 2001).

Each subsequent tectonic event that participated in continent growth - whether compressional or extensionalreactivated structural zones, localized sedimentary basins, and magmatism. Many of these structural zones became pathways that influenced and controlled mineralizing fluids. In addition, orogenic and postorogenic processes that act on or within the crust remobilize and recycle metals and contribute to mineral deposit formation (see discussion and references in Groves and others, 1998; Leahy and others, 2005; Groves and Bierlein, 2007).

Further, reactivation of deep-seated structural framework components inherited from earlier events may help to focus younger deformation and to provide structural pathways as suggested for the Colorado Mineral Belt, for example (Tweto and Sims, 1963; Karlstrom and Humphries, 1998). Similarly, the juvenile crust of the concealed Paleoproterozoic Great Falls tectonic zone may have contributed metals to the Cretaceous and Tertiary upper-crustal $\mathrm{Cu}-\mathrm{Mo}$ deposits (Klein and Sims, 2007) of the Idaho-Montana porphyry belt (Armstrong and others, 1978; Rostad, 1978). The importance of structural reactivation of basement features in forming multistage mineral belts, such as the world-class Carlin-type gold deposits of the Great Basin is also well documented (Emsbo and others, 2006). Accordingly, orogenic overprinting and recycling have the potential to form complex and long-lived mineral belts that contain multiple ages and styles of mineral deposits.

The map presented herein provides one possible template for basement domains. It provides a dataset evaluating the types, distribution, and origins of metal endowments in basement domains and for how continent-scale structural events influenced the composition and location of younger mineral deposits. The map broadly identifies domain elements of the United States including Alaska so that (1) major regional structural zones within and between them can be identified and evaluated in terms of their role as conduits for mineralizing systems and (2) continent-scale magmatic and hydrothermal systems can be identified in terms of their origin in response to rift or collisional events and their capability to have introduced metals into the upper crust or remobilized metals in the upper crust. Future mineral resource assessments can utilize the framework data included as part of this map and, digitally layered with other national-scale geoscience datasets (figs. 6 and 7), these data can be used to evaluate continent-scale mineral resource potential and to define associations among certain types of mineral deposits in relation to the original tectonic setting of host basement domains. The map synthesizes an approach to defining the tectonic and paleogeographic evolution of metal-endowed regions of the United States. Better discrimination of basement character, origin, and relation to mineral deposits can be used to test and refine this approach.

\section{Summary}

The approach used to create this basement domain map employs the terrane concept, which recognizes that continents are composed of many crustal fragments of different ages and types. Further, the study synthesizes the variety of processes through which terrane fragments become continental crust and basement. The processes of continental-crust formation and evolution into basement domains have changed through the course of planetary development.

Two basic styles of continental growth (accretion) contributed to U.S. basement assembly. The most commonly recognized type of accretion was collision-related consumption of crust and juxtaposition of exotic and native fragments against (adjacent, onto, and under) the developing continental margin (typically seamounts, island arc chains, backarc basins, and tectonized fragments such as melange). These processes either resulted in or were preceded by collisions of continental masses, causing both orogenic thickening and attachment of allochthonous continental basement (for example, the Appalachian orogenic cycle). Translation and reattachment of native basement slices is a variant of the first type of accretion. Accretion caused by extension resulted from variable subduction rates (slab rollback) along noncollisional margins. Extensional accretionary orogenesis is typically nondestructive and generates growth of continental crust outward from the preexisting continental margin.

Synthesizing the original tectonic setting and original metals accumulation, in relation to basement evolution, highlights potential innate metal endowments in diverse basement domains. Cratons resist tectonic reactivation and deformation and, thus, their metals endowments tend to be preserved in the state prevailing during formation and cratonization. Associating the origin of basement domains and their original metal endowments may clarify relationships among various domains and spatially associated mineral deposits of various types and ages. The accuracy and validity of regional mineral resource assessments may be improved by considering basement origin, composition, history, and architecture. 


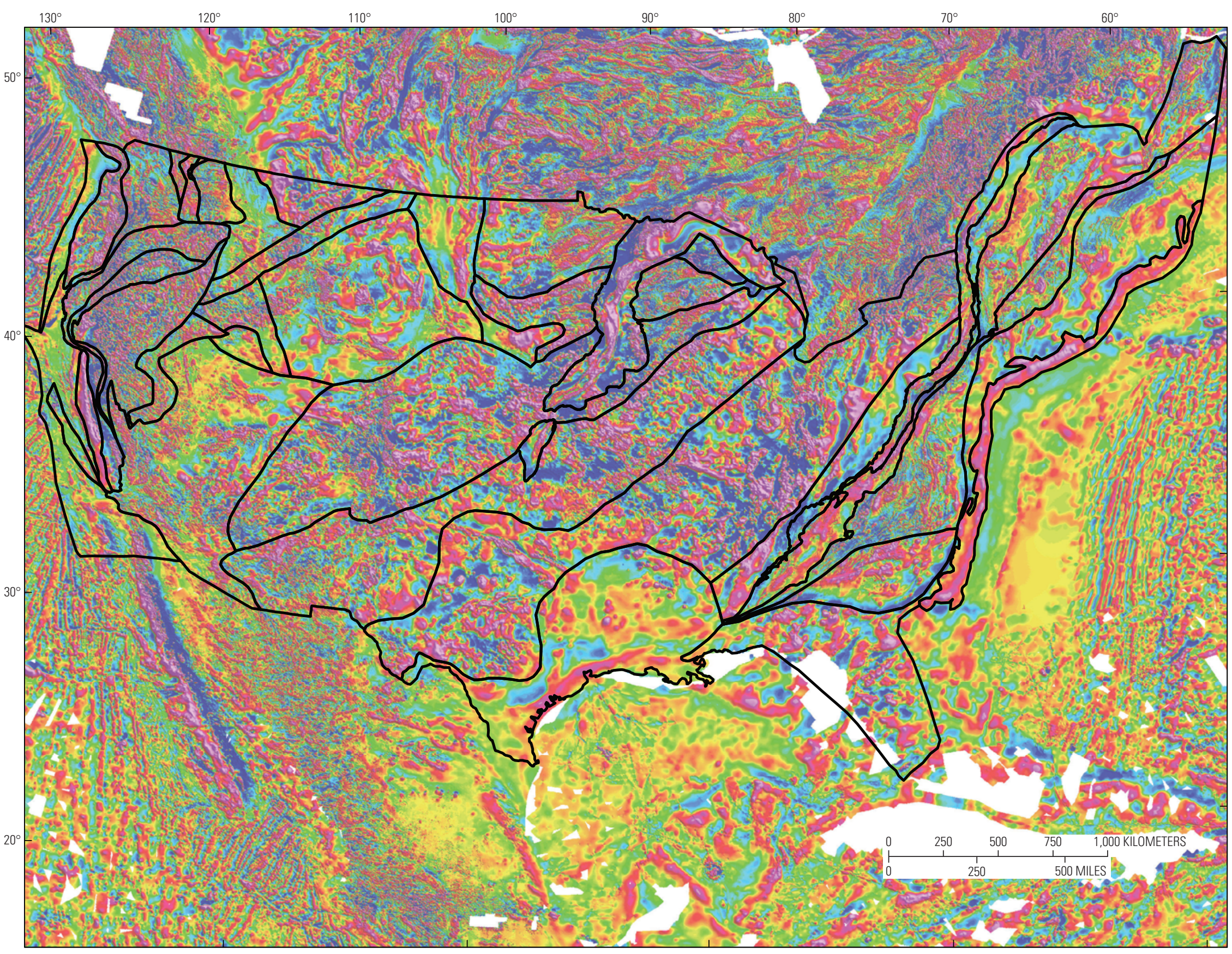




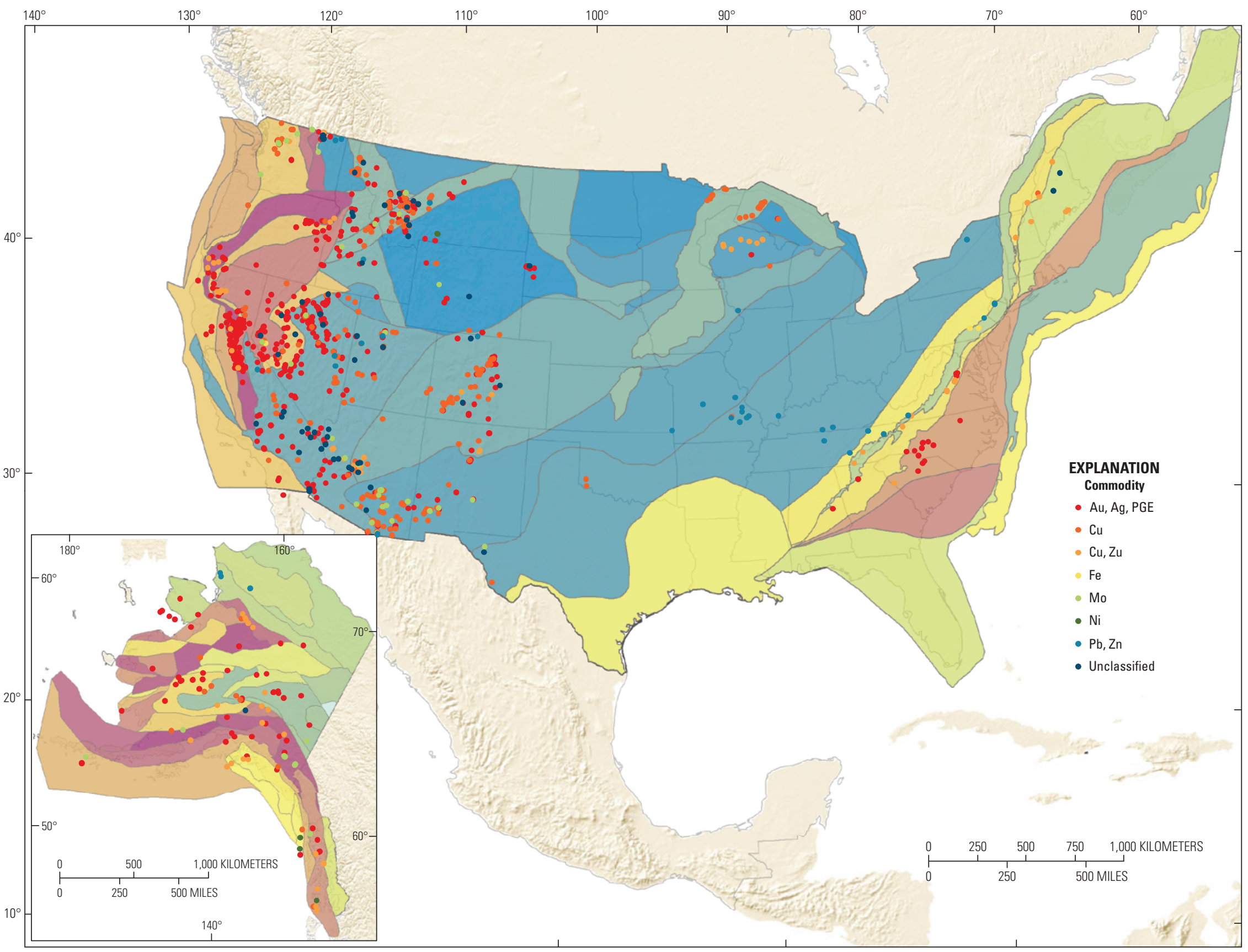

Figure 7. Basement domains layered with plot of principal metal deposits database revised from Long and others (1998) showing gold, silver, copper, platinum-group elements, nickel, lead, zinc and unclassified deposits of the conterminous United States and Alaska. 


\section{References Cited}

Adam, John, Rushmer, T., O’Neil, J., and Francis, D., 2012, Hadean greenstones from the Nuvvuagittuq fold belt and the origin of the Earth's early continental crust: Geology, v. 40, p. 363-366; doi:10.1130/G32623.1.

Akinin, V.V., Miller, E.L., and Wooden, J.L., 2009, Petrology and geochronology of crustal xenoliths from the Bering Strait region-Linking deep and shallow processes in extending continental crust, in Miller, R.B., and Snoke, A.W., eds., Crustal cross sections from the western North American Cordillera and elsewhere-Implications for tectonic and petrologic processes: Geological Society of America Special Paper 456, p. 39-68.

Albers, J.P., 1983, Distribution of mineral deposits in accreted terranes and cratonal rocks of the western United States: Canadian Journal of Earth Sciences, v. 20, p. 1019-1029.

Aleinikoff, J.N., Plafker, G., and Nokleberg, W.J., 1988, Middle Pennsylvanian plutonic rocks along the southern margin of the Wrangellia Terrane, in Galloway, J.P., and Hamilton, T.D., eds., Geologic studies in Alaska by the U.S. Geological Survey during 1987: U.S. Geological Survey Circular 1016, p. 110-113.

Aleinikoff, J.N., Reed, J.C., and Wooden, J.L., 1993, Lead isotopic evidence for the origin of Paleo- and Mesoproterozoic rocks of the Colorado Province, U.S.: Precambrian Research, v. 63, p. 97-122; doi: 10.1016/03019268(93)90007-O.

Alt, J.C., Teagle, D.A.H., Brewer, T.S., Shanks, W.C., III, and Halliday, A.N., 1998, Alteration and mineralization of an oceanic forearc and the ophiolite-ocean crust analogy: Journal of Geophysical Research-Solid Earth, v. 103, no. B6, p. $12,365-12,380$.

Amato, J.M., Bogar, M.J., Gehrels, G.E., Farmer, G.L., and McIntosh, W.C., 2007, The Tlikakila complex in southern Alaska-A suprasubduction-zone ophiolite between the Wrangellia Composite terrane and North America, in Ridgway, K.D., Trop, J.M., Glen, J.M.G., and O’Neill, J.M., eds., Tectonic growth of a collisional continental marginCrustal evolution of southern Alaska: Geological Society of America Special Paper 431, p. 227-252.

Amato, J.M., and Pavlis, T.L., 2010, Detrital zircon ages from the Chugach Terrane, southern Alaska, reveal multiple episodes of accretion and erosion in a subduction complex: Geology, v. 38, p. 459-462.

Amato, J.M., Toro, J., Miller, E.L., Gehrels, G.E., Farmer, G.L., Gottlieb, E.S., and Till, A.B., 2009, Late ProterozoicPaleozoic evolution of the Arctic Alaska-Chukotka terrane based on U-Pb igneous and detrital zircon ages - Implications for Neoproterozoic paleogeographic reconstructions: Geological Society of America Bulletin, v. 121, p. 1219-1235.
American Geological Institute, 2008, Glossary of geology (5th ed.): Falls Church, Virginia, USA, American Geological Institute, $779 \mathrm{p}$.

Anderson, J.L., 1983, Proterozoic anorogenic granite plutonism of North America, in Medaris, L.G.J., Byers, C.W., Mickelson, D.M., and Shanks, W.C., eds., Proterozoic geology-Selected papers from an international Proterozoic symposium: Geological Society of America Memoir 161, p. 133-152.

Anderson, J.L., and Morrison, J., 1992, The role of anorogenic granites in the Proterozoic crustal development of North America, in Condie, K.C., ed., Proterozoic crustal evolution: Amsterdam, Elsevier Science Publishers, p. 263-299.

Armstrong, R.L., 1988, Mesozoic and early Cenozoic magmatic evolution of the Canadian Cordillera, in Clark, S.P., Jr., Burchfiel, B.C., and Suppe, J., eds., Processes in continental lithospheric deformation: Geological Society of America Special Paper 218, p. 55-91.

Armstrong, R.L., 1991, The persistent myth of crustal growth: Australian Journal of Earth Sciences, v. 38, p. 613-630.

Armstrong, R.L., Hollister, V.F., and Harakel, J., 1978, K-Ar dates for mineralization in the White Cloud-Cannivan porphyry molybdenum belt of Idaho and Montana: Economic Geology, v. 73, p. 94-108.

Armstrong, R.L., Taubeneck, W.H., and Hales, P.L., 1977, Rb/ $\mathrm{Sr}$ and $\mathrm{K} / \mathrm{Ar}$ geochronometry of Mesozoic granitic rocks and their $\mathrm{Sr}$ isotopic composition, Oregon, Washington, and Idaho: Geological Society of America Bulletin, v. 88, p. 397-411.

Arndt, N.T., Lesher, C.M., and Czamanske, G.K., 2005, Mantle-derived magmas and magmatic Ni-Cu- (PGE) deposits: Economic Geology 100th Anniversary Volume, p. 5-24.

Arth, J.G., Criss, R.E., Zmuda, C.C., Foley, N.K., Patton, Jr., W.W., and Miller, T. P., 1989b, Remarkable isotopic and trace element trends in potassic through sodic Cretaceous plutons of the Yukon-Koyukuk basin, Alaska, and the nature of the lithosphere beneath the Koyukuk terrane: Journal of Geophysical Research, v. 94, p. 15,957-15,968.

Arth, J.G., Zmuda, C.C., Foley, N.K., Criss, R.E., Patton, W.W., Jr., and Miller, T.P., 1989a, Isotopic and trace element variations in the Ruby batholith, Alaska, and the nature of the deep crust beneath the Ruby and Angayucham terranes: Journal of Geophysical Research, v. 94, p. 15,941-15,955.

Babcock, R.S., Burmester, R.F., Engebretson, D.C., Warnock, A., and Clack, K.P., 1992, A rifted margin origin for the Crescent basalts and related rocks in the northern Coast Range volcanic province, Washington and British Columbia: Journal of Geophysical Research v. 97, no. B5, p. 6799-6821. 
Bacon, C.R., Vazquez, J.A., and Wooden, J.L., 2012, Peninsular terrane basement ages recorded by Paleozoic and Paleoproterozoic zircon in gabbro xenoliths and andesite from Redoubt volcano, Alaska: Geological Society of America Bulletin, v. 124, p. 24-34.

Baird, D.J., Nelson, K.D., Knapp, J.H., Walters, J.J., and Brown, L.D., 1996. Crustal structure and evolution of the Trans-Hudson orogen-Results from seismic reflection profiling: Tectonics, v. 15, p. 416-426.

Barbeau, D.L., Jr., Ducea, M.N., Gehrels, G.E., Kidder, S., Wetmore, P.H., and Saleeby, J.B., 2005, U-Pb detrital-zircon geochronology of northern Salinian basement and cover rocks: Geological Society of America Bulletin, v. 117, p. 466-481.

Barr, S.M., Raeside, R.P., and White, C.E., 1998, Geological correlations between Cape Breton Island and Newfoundland, northern Appalachian orogeny: Canadian Journal of Earth Science, v. 35, p. 1252-1270.

Barrie, C.T., Hannington, M.D., and Bleeker, W., 1999, The giant Kidd Creek volcanic-associated massive sulfide deposit, Abitibi subprovince, Canada, in Barrie, C.T., and Hannington, M.D., eds., Volcanic-associated massive sulfide deposits-Processes and examples in modern and ancient settings: Reviews in Economic Geology, v. 8, p. 247-259.

Barth, A.P., Wooden, J.L., Coleman, D.S., and Fanning, C.M., 2000, Geochronology of the Proterozoic basement of southwesternmost North America, and the origin and evolution of the Mojave crustal province: Tectonics, v. 19, p. 616-629; doi: 10.1029/1999TC001145.

Barth, A.P., Wooden, J.L., Grove, M., Jacobson, C.E., and Pedrick, J.N., 2003, U-Pb zircon geochronology of rocks in the Salinas Valley region of California-A reevaluation of the crustal structure and origin of the Salinian block: Geology, v. 31, p. 517-520.

Bekker, Andrey, Slack, J.F., Planavsky, N., Krapež, B., Hofmann, N., Konhauser, K.O., and Rouxel, O.J., 2010, Iron formation-The sedimentary product of a complex interplay among mantle, tectonic, oceanic, and biospheric processes: Economic Geology, v. 105, p. 467-508; doi: 10.2113/ gsecongeo.105.3.467.

Ben-Avraham, Zvi, and Nur, A., 1983, An introductory overview to the concept of displaced terranes: Canadian Journal of Earth Sciences, v. 20, p. 994-999; doi: 10.1139/e83-090.

Benford, B., Crowley, J., Schmitz, M., Northrup, C.J., and Tikoff, B., 2010, Mesozoic magmatism and deformation in the northern Owyhee Mountains, Idaho: Implications for along-zone variations for the western Idaho shear zone: Lithosphere, v. 2, p. 93-118.

Berger, B.R., Ayuso, R.A., Wynn, J.C., and Seal, R.R., 2008, Preliminary model of porphyry copper deposits: U.S. Geological Survey Open-File Report 2008-1321, 55 p.
Betts, P.G., and Giles, D., 2006, The 1800-1100 Ma tectonic evolution of Australia: Precambrian Research, v. 144, p. $92-125$.

Bickford, M.E., and Hill, B.M., 2007, Does the arc accretion model adequately explain the Paleoproterozoic evolution of southern Laurentia?: An expanded interpretation: Geology, v. 35, p. 167-170; doi: 10.1130/G23174A.1.

Bickford, M.E., Wooden, J.L., and Bauer, R.L., 2006, SHRIMP study of zircons from early Archean rocks in the Minnesota River Valley-Implications for the tectonic history of the Superior Province: Geological Society of America Bulletin, v. 118, p. 94-108; doi: 10.1130/B25741.1.

Bleeker, Wouter, 2003, The late Archean record-A puzzle in ca. 35 pieces: Lithos, v. 71, p. 95-134.

Boerboom, T.J., and the NICE geo-group, 2005, Geologic map of Precambrian basement rocks in Wisconsin, Minnesota, and Iowa: http://www.mngs.umn.edu/nicegeo/pdfs/ labeled_terrane.pdf.

Boerner, D.E., Craven, J.A., Kurtz, R.D., Ross, G.M., and Jones, F.W., 1998, The Great Falls tectonic zone-Suture or intracontinental shear zone?: Canadian Journal of Earth Sciences, v. 35, p. 175-183.

Bowring, S.A., and Karlstrom, K.E., 1990, Growth, stabilization, and reactivation of Proterozoic lithosphere in the southwestern United States: Geology, v. 18, p. 1203-1206.

Box, S.E., Moll-Stalcup, E.J., Frost, T.P., and Murphy, J.M., 1993, Preliminary geologic map of the Bethel and southern Russian Mission quadrangles, Alaska: U.S. Geological Survey Miscellaneous Field Studies Map M-2226-A, scale 1:250,000, $20 \mathrm{p}$.

Box, S.E., Moll-Stalcup, E.J., Wooden, J.L., and Bradshaw, J.Y., 1990, Kilbuck terrane-Oldest known rocks in Alaska: Geology, v. 18, p. 1219-1222.

Box, S.E., and Patton, W.W., Jr., 1989, Igneous history of the Koyukuk terrane, western Alaska - Constraints on the origin, evolution and ultimate collision of an accreted island arc terrane: Journal of Geophysical Research, v. 94, p. $15,843-15,867$.

Bradley, D.C., Dumoulin, J., Layer, P., Sunderlin, D., Roeske, S., McClelland, W., Harris, A.G., Abbott, G., Bundtzen, T.K., and Kusky, T., 2003, Late Paleozoic orogeny in Alaska's Farewell terrane: Tectonophysics, v. 372, p. 23-40.

Bradley, D.C., McClelland, W.C., Friedman, R.M., O'Sullivan, P., Layer, P.W., Miller, M.L., Dumoulin, J.A., Till, A.B., Wooden, J.L., and Abbott, J.G., 2014, Proterozoic geochronological links between the Farewell, Kilbuck and Arctic Alaska terranes: Journal of Geology, v. 133, no. 3, p. 237-258; doi: 10.1086/675663. 
Bradley, D.C., McClelland, W.C., Wooden, J., Till, A.B., Roeske, S., Miller, M.L., Karl, S., and Abbott, J.G., 2007, Detrital zircon geochronology of some Neoproterozoic to Triassic rocks in interior Alaska: Geological Society of America Special Paper 431, p. 155-180.

Brandon, M.T., Roden-Tice, M.K. and Garver, J.I., 1998, Late Cenozoic exhumation of the Cascadia accretionary wedge in the Olympic Mountains, northwest Washington State: Geological Society of America Bulletin, v. 110, p. $985-1009$.

Brown, S.R., Gibson, H.D., Andrews, G.D.M., Thorkelson, D.J., Marshall, D.M., Vervoort, J.D., and Rayner, N., 2012, New constraints on Eocene extension within the Canadian Cordillera and identification of Phanerozoic protoliths for footwall gneisses of the Okanagan Valley shear zone: Lithosphere, v. 4, p. 354-377; doi: 10.1130/L199.1.

Buhlmann, A.L., Cavell, P., Burwash, R.A., Creaser, R.A., and Luth, R.W., 2000, Minette bodies and cognate micaclinopyroxenite xenoliths from the Milk River area, southern Alberta-Records of a complex history of the northernmost part of the Archean Wyoming craton: Canadian Journal of Earth Sciences, v. 37, p. 1629-1650.

Burger, H.R., 2004, General geology and tectonic setting of the Tobacco Root Mountains, Montana, in Brady, J.B., and others, eds., Precambrian geology of the Tobacco Root Mountains, Montana: Geological Society of America Special Paper 377, p. 1-14.

Cady, J.W., 1975, Magnetic and gravity anomalies in the Great Valley and western Sierra Nevada metamorphic belt, California: Geological Society of America Special Paper $168,56 \mathrm{p}$.

Cameron, Angie, 2010, Geochronology of the lower Wildhorse gneiss complex, Pioneer Mountains, Custer County, Idaho: Senior thesis, Idaho State University, Pocatello, Idaho, 43 p.; http://geology.isu.edu/thesis/Cameron_Angie SrThesis2010.pdf.

Carlson, M.P., 2007, Precambrian accretionary history and Phanerozoic structures-A unified explanation for the tectonic architecture of the Nebraska region, USA, in Hatcher, R.D., Jr., Carlson, M.P., McBride, J.H., and Martínez Catalán, J.R., eds., 4-D Framework of Continental Crust: Geological Society of America Memoir 200, p. 321-326, doi: 10.1130/2007.1200(15).

Carlson, D.H., Fleck, R., Moye, F.J., and Fox, K.F., 1991, Geology, geochemistry, and isotopic character of the Colville igneous complex, northeastern Washington: Journal of Geophysical Research, v. 96, no. B8, p. 13,313-13,333.

Cawood, P.A., and Hawkesworth, C.J., 2012, Temporal relations between mineral deposits and global tectonic cycles-Implications for prospectivity, in Jenkin, G.R.T., Lusty, P.A.J., McDonald, I., Smith, M.P., Boyce, A J., and Wilkinson, J.J. (eds.), Ore deposits in an evolving earth: Geological Society [London] Special Publications 393; doi:10.1144/SP393.1.

Cawood, P.A., Hawkesworth, C.J., and Dhuime, B., 2013, The continental record and the generation of continental crust: Geological Society of America Bulletin, v. 125, p. 14-32; doi: 10.1130/B30722.1.

Cawood, P.A., Kroner, A., and Pisarevsky, S., 2006, Precambrian plate tectonics - Criteria and evidence: GSA Today, v. 16, p. 4-11.

Cawood, P.A., Leitch, E.C., Merle, R.E., and Nemchin, A.A., 2011, Orogenesis without collision-Stabilizing the Terra Australis accretionary orogen, eastern Australia: Geological Society of America Bulletin, v. 123, p. 2240-2255; doi:10.1130/B30415.1.

Cawthorn, R.G., Barnes, S.J., Ballhaus, C., and Malitch, K.N., 2005, Platinum group element, chromium, and vanadium deposits in mafic and ultramafic rocks: Economic Geology 100th Anniversary Volume, p. 215-250.

Cheney, E.S., Rasmussen, M.G., and Miller, M.G., 1994, Major faults, stratigraphy, and identity of Quesnellia in Washington and adjacent British Columbia, in Lasmanis, Raymond, and Cheney, E.S., eds., Regional geology of Washington State, Washington Division of Geology and Earth Resources Bulletin 80, p. 49-71.

Clautice, K.H., and Newberry, R.J., 2006, Chulitna-Space alien or not [abs.]: Geological Society of America Abstracts with Programs, v. 38, no. 5, p. 91.

Collins, W.J., 2002a, Hot orogens, tectonic switching, and creation of continental crust: Geology, 535-538.

Collins, W.J., 2002b, The nature of extensional accretionary orogens: Tectonics, v. 21, p. 1-12; doi: 10.1029/2000TC001272.

Colpron, Maurice, Nelson, J.L., and Murphy, D.C., 2007, Northern Cordilleran terranes and their interactions through time: GSA Today, v. 17, p. 4-10; doi: 10.1130/GSAT01704-5A.1.

Colpron, Maurice, and Price, R.A., 1995, Tectonic significance of the Kootenay terrane, southeastern Canadian Cordillera-An alternative model: Geology, v. 23, p. 25-28.

Condie, K.C., 1982, Plate-tectonics model for Proterozoic continental accretion in the southwestern United States: Geology, v. 10, p. 37-42.

Condie, K.C., 1992, ed., Proterozoic crustal evolution: Amsterdam, Elsevier Science Publishers, 536 p.

Condie, K.C., 2005, Earth as an evolving planetary system: Amsterdam, Elsevier Science Publishers, 574 p.

Condie, K.C., 2007, The distribution of Paleoarchean crust, in Van Kranendonk, M.J., Smithies, R.H., and Bennett, V.C., eds., Earth's oldest rocks, Amsterdam, Elsevier Publishers, Ch. 1.2, p. 9-18. 
Cooper, A.K., and Marlow, M.S., 1983, Preliminary results of geophysical and geological studies of the Bering Sea shelf during 1982: U.S. Geological Survey Open-File Report 83-322, 8 p.

Corrigan, David, Hajnal, Z., Nemeth, B., and Lucas, S.B., 2005, Tectonic framework of a Paleoproterozoic arc-continent to continent-continent collisional zone, Trans-Hudson orogen, from geological and seismic reflection studies: Canadian Journal of Earth Sciences, v. 42, p. 421-434.

Cox, D.P., and Singer, D.A., 1986, eds., Mineral deposit models: U.S. Geological Survey Bulletin 1693, 379 p.

Dahl, P.S., Hamilton, M.A., Wooden, J.L., Foland, K.A., Frei, R., McCombs, J.A., and Holm, D.K., 2006, 2480 Ma mafic magmatism in the northern Black Hills, South Dakota-A new link connecting the Wyoming and Superior cratons: Canadian Journal of Earth Sciences v. 43, p. 1579-1600.

Dahl, P.S., Holm, D.K., Gardner, E.T., Hubacher, F.A., and Foland, K.A., 1999, New constraints on the timing of early Proterozoic tectonism in the Black Hills (South Dakota), with implications for the docking of the Wyoming Province with Laurentia: Geological Society of America Bulletin, v. 111, p. 1335-1349.

Dall'Agnol, Roberto, Frost, C.D., and Ramo, O.T., 2012, IGCP Project 510 "A-type" Granites and Related Rocks through Time-Project vita, results, and contribution to granite research (editorial): Lithos, v. 151, p. 1-16.

Dallmeyer, R.D., 1989, ${ }^{40} \mathrm{Ar} /{ }^{39} \mathrm{Ar}$ ages from subsurface crystalline basement of the Wiggins uplift and southwesternmost Appalachian Piedmont-Implications for late Paleozoic terrane accretion during assembly of Pangea: American Journal of Science, v. 289, p. 812-833.

Daniel, C.G., Pfeifer, L.S., Jones, J.V., III, and McFarlane, C.M., 2013, Detrital zircon evidence for non-Laurentian provenance, Mesoproterozoic (ca. 1490-1450 Ma) deposition and orogenesis in a reconstructed orogenic belt, northern New Mexico, USA - Defining the Picuris orogeny: Geological Society of America Bulletin, v. 125, p. 1423-1441.

Dann, J.C., 1997, Pseudostratigraphy and origin of the early Proterozoic Payson ophiolite, central Arizona: Geological Society of America Bulletin, v. 109, p. 347-365; doi: 10.1130/0016-7606(1997)109.

Dawson, K.M., Panteleyev, A., Sutherland Brown, A., and Woodsworth, G.J., 1991, Regional metallogeny, in Gabrielse, Hugh, and Yorath, C.J., eds., Geology of the Cordilleran orogen in Canada: Geological Society of America Geology of North America, v. G-2, p. 709-768.

De Wit, M.J., and Thiart, C., 2005, Metallogenic fingerprints of Archaean cratons, in McDonald, Iain, Boyce, A.J., Butler, I.B., Herrington, R.J., and Polya, D.A., eds., Mineral deposits and earth evolution, Geological Society [London] Special Publications 248, p. 59-70.

Decker, John, Bergman, S.C., Blodgett, R.B., Box, S.E., Bundtzen, T.K., Clough, J.G., Coonrad, W.L., Gilbert, W.G., Miller, M.L., Murphy, J.M., Robinson, M.S., and Wallace, W.K., 1994, Geology of southwestern Alaska, in Plafker, George, and Berg, H.C., eds., The geology of Alaska: Geological Society of America Geology of North America, v. G-1, p. 285-310.

Dehler, C.M., Sprinkel, D.A., and Porter, S.M., 2005, Neoproterozoic Uinta Mountain Group of northeastern UtahPre-Sturtian geographic, tectonic, and biologic evolution, in Pederson, J.L., and Dehler, C.M., eds., Interior western United States: Geological Society of America Field Guide 6, p. 1-25; doi: 10.1130/2005.fl d006(01).

DeMatties, T.A., 1994, Early Proterozoic volcanogenic massive sulfide deposits in Wisconsin-An overview: Economic Geology, v. 89, p. 1122-1151.

Detterman, R.L., Miller, J.W., Case, J.E., Wilson, F.H., and Yount, M.E., 1996, Stratigraphic framework of the Alaska peninsula: U.S. Geological Survey Bulletin 1969-A, 74 p.

Dewey, J.F., 2007, The secular evolution of plate tectonics and the continental crust-An outline, in Hatcher, R.D., Jr., Carlson, M.P., McBride, J.H., and Martínez Catalán, J.R., eds., 4-D framework of continental crust: Geological Society of America Memoir 200, p. 1-7; doi: 10.1130/2007.1200(01).

DeWitt, E.H., Premo, W.R., and Klein, T., 2010a, The early Proterozoic Poudre basin, an important constraint of 1.77-1.73-Ga tectonic events in northern Colorado [abs.]: Geological Society of America Abstracts with Programs, v. 42 , no. 5 , p. 654 .

DeWitt, E.H., Premo, W.R., and Klein, T., 2010b, Factors controlling generation and distribution of 1400-Ma plutons in Colorado [abs.]: Geological Society of America Abstracts with Programs, v. 42, no. 5, p. 654.

DGGS Staff, Zonge Engineering Research Organization, Inc., and GEONEX Aero Service, 1995, Total field magnetics of the southeastern Bethel basin, Alaska: Alaska Division of Geological and Geophysical Surveys Report of Investigation 95-1, 2 sheets, scale 1:125,000.

Dickinson, W.R., 2006, Geotectonic evolution of the Great Basin: Geosphere, v. 2, p. 353-368.

Dickinson, W.R., 2008, Accretionary Mesozoic-Cenozoic expansion of the Cordilleran continental margin in California and adjacent Oregon: Geosphere, v. 4, p. 329-353.

Dorsey, R.J., and LaMaskin, T.A., 2007, Stratigraphic record of Triassic-Jurassic collisional tectonics in the Blue Mountains Province, northeastern Oregon: American Journal of Science, v. 307, p. 1167-1193. 
Dostal, Jaroslav, Church, B.N., and Hoy, T., 2001, Geological and geochemical evidence for variable magmatism and tectonics in the southern Canadian Cordillera-Paleozoic to Jurassic suites, Greenwood, southern British Columbia: Canadian Journal Earth Sciences, v. 38, p. 75-90.

Doughty, P.T., and Chamberlain, K.R., 2007, Age of Paleoproterozoic basement and related rocks in the Clearwater complex, northern Idaho, U.S.A., in Link, P.K., and Lewis, R.S., eds., Proterozoic geology of western North America and Siberia: Society for Sedimentary Geology Special Publication 86, p. 9-36.

Doughty, P.T., and Chamberlain, K.R., 2008, Protolith age and timing of Precambrian magmatic and metamorphic events in the Priest River complex, northern Rockies: Canadian Journal of Earth Sciences, v. 45, p. 99-116; doi: 10.1139/ E07-067.

Doughty, P.T., Price, R.A., and Parrish, R.R., 1998, Geology and U-Pb Geochronology of Archean basement and Proterozoic cover in the Priest River complex, northwestern United States, and their implications for Cordilleran structure and Precambrian continent reconstructions: Canadian Journal of Earth Sciences, v. 35, p. 39-54.

Dover, J.H., 1994, Geology of part of east-central Alaska, in Plafker, George, and Berg, H.C., The geology of Alaska: Geological Society of America Geology of North America, v. G-1, p. 153-203.

Drake, A.A., Jr., 1989, Metamorphic rocks of the Potomac terrane in the Potomac Valley of Virginia and Maryland, in International Geological Congress, 28th, Field Trip Guidebook T202: Washington, D.C., American Geophysical Union, $22 \mathrm{p}$.

Duebendorfer, E.M., Chamberlain, K.R., and Fry, B., 2006, Mojave-Yavapai boundary zone, southwestern United States - A rifting model for the formation of an isotopically mixed crustal boundary zone: Geology, v. 34, p. 681-684; doi: 10.1130/G22581.1.

Duebendorfer, E.M., Chamberlain, K.R., and Jones, C.S., 2001, Paleoproterozoic tectonic history of the Mojave-Yavapai boundary zone: Perspective from the Cerbat Mountains, northwestern Arizona: Geological Society of America Bulletin, v. 113, p. 575-590; doi: 10.1130/0016-7606(2001)113<0575:PTHOTC $>2.0 . C O ; 2$.

Dumond, Gregory, Mahan, K.H., Williams, M.L., and Karlstrom, K.E., 2007, Crustal segmentation, composite looping pressure-temperature paths, and magma-enhanced metamorphic field gradients - Upper Granite Gorge, Grand Canyon, USA: Geological Society of America Bulletin, v. 119, p. 202-220; doi: 10.1130/B25903.1.

Dusel-Bacon, Cynthia, and Williams, I.S., 2009, Evidence for prolonged mid-Paleozoic plutonism and ages of crustal sources in east-central Alaska from SHRIMP U-Pb dating of syn-magmatic, inherited and detrital zircon: Canadian Journal of Earth Sciences, v. 46, p. 21-39.

Dutch, S.I., and Nielsen, P.A., 1990, The Archean Wyoming province and its relations with adjacent Proterozoic provinces, in Lewry, J.F., and Stauffer, M.R., eds., The Early Proterozoic Trans-Hudson orogen of North America: Geological Association of Canada Special Paper 37, p. 287-300.

Edelman, S.E., and Sharp, W.D., 1989, Terranes, early faults, and pre-Late Jurassic amalgamation of the western Sierra Nevada metamorphic belt, California: Geological Society of America Bulletin, v. 101, p. 1420-1433.

Egan, S.S., and Meredith, D.J., 2007, A kinematic modelling approach to lithosphere deformation and basin formationApplication to the Black Sea, in Karner, G.D., Manatschal, G., and Pinheiro, L.M., eds., Imaging, mapping and modelling continental lithosphere extension and breakup: Geological Society [London] Special Publications 282, p. 173-198; doi: 10.1144/SP282.9.

Egger, A.E., Miller, E.L., Dumitru, T.A., and Wooden, J.L., 2003, Timing and nature of Tertiary plutonism with regard to extension in the Grouse Creek Mountains, Utah: International Geology Reviews, v. 45, p. 497-532.

Eldholm, Olav, Skogseid, J., and Planke, S., 2000, Atlantic volcanic margins - A comparative study, in Nottvedt, Arvid, Larsen, B.T., Olaussen, S., Torudbakken, B., Skogseid, J., Gabrielsen, R.H., Brekke, H., and Birkeland, O., eds., Dynamics of the Norwegian margin: Geological Society [London] Special Publications 167, 472 p.

Emsbo, Poul, Groves, D.I., Hofstra, A.H., and Bierlein, F.P., 2006, The giant Carlin gold province-A protracted interplay of orogenic, basinal, and hydrothermal processes above a lithospheric boundary: Mineralia Deposita, v. 41, p. 517-525; doi: 10.1007/s00126-006-0085-3.

Ernst, W.G., 2011, Accretion of the Franciscan complex attending Jurassic-Cretaceous geotectonic development of northern and central California: Geological Society of America Bulletin, v. 123, p. 1667-1678.

Ernst, W.G., Snow, C.A., and Scherer, H.H., 2008, Mesozoic transpression, transtension, subduction and metallogenesis in northern and central California: Terra Nova, 20, p. 394-413.

Evans, K.V., and Zartman, R.E., 1990, U-Th-Pb and Rb-Sr geochronology of middle Proterozoic granite and augen gneiss, Salmon River Mountains, east-central Idaho: Geological Society of America Bulletin, v. 102, p. 63-73; doi: 10.1130/0016-7606(1990)102<0063:UTPARS >2.3.CO;2. 
Farris, D.W., 2009, Construction and evolution of the Kodiak Talkeetna arc crustal section, southern Alaska, in Miller, R.B., and Snoke, A.W., eds., Crustal cross sections from the western North American Cordillera and elsewhere-Implications for tectonic and petrologic processes: Geological Society of America Special Paper 456, p. 69-96.

Ferguson, C.B., Duebendorfer, E.M., and Chamberlain, K.R., 2007, Synkinematic intrusion of the 1.4-Ga Boriana Canyon pluton, northwestern Arizona - Implications for ca. 1.4-Ga regional strain in the western United States: Journal of Geology, v. 112, p. 165-183; doi: 0022-1376/2004/112020003 .

Fischer, C.M., Loewy, S.L., Miller, C.F., Berquist, P., Van Schmus, W.R., Hatcher, R.D., Jr., Wooden, J.L., and Fullager, P.D., 2010, Whole-rock $\mathrm{Pb}$ and $\mathrm{Sm}-\mathrm{Nd}$ isotopic constraints on the growth of southeastern Laurentia during Grenville orogenesis: Geological Society of America Bulletin, v. 122, p. 1646-1659.

Fleck, R.J., and Criss R.E., 2007, Location, age, and tectonic significance of the western Idaho suture zone, in Kuntz, M.A., and Snee, L.W., eds., Geological studies of the Salmon River suture zone and adjoining areas, west-central Idaho and eastern Oregon: U.S. Geological Survey Professional Paper 1738, p. 15-50.

Fleck, R.J., and Gunn, S.H., 1991, The use of integrated geologic, geochemical, and isotopic studies in the identification and interpretation of lithospheric boundaries in the northwestern United States [abs.]: Geological Society of America Abstracts with Programs, v. 23, p. 210.

Foster, D.A., and Fanning, C.M., 1997, Geochronology of the northern Idaho batholith and the Bitterroot metamorphic core complex-Magmatism preceding and contemporaneous with extension: Geological Society of America Bulletin, v. 109, no. 4, p. 379-394; doi: 10.1130 /0016-7606(1997)109<0379:GOTNIB>2.3.CO;2.

Foster, D.A., Mueller, P.A., Vogl, J.J., Mogk, D.W., and Wooden, J.L., 2006, Proterozoic evolution of the western margin of the Wyoming craton-Implications for the tectonic and magmatic evolution of the northern Rocky Mountains: Canadian Journal of Earth Sciences, v. 43, p. 1601-1619.

Franklin, J.M., Gibson, H.L., Jonasson, I.R., and Galley, A.G., 2005, Volcanogenic massive sulfide deposits: Economic Geology 100th Anniversary Volume, p. 523-560.

Fuis, G.S., Moore, T.E., Plafker, G., Brocher, T.M., Fisher, M.A., Mooney, W.D., Nokleberg, W.J., Page, R.A., Beaudoin, B.C., Christensen, N.I., Levander, A.R., Lutter, W.J., Saltus, R.W., and Ruppert, N.A., 2008, Trans-Alaska Crustal Transect and continental evolution involving subduction underplating and synchronous foreland thrusting: Geology, v. 36, p. 267-270.
Galley, A.G., Hannington, M., and Jonasson, I., 2007, Volcanogenic massive sulphide deposits, in Goodfellow, W.D., ed., Mineral deposits of Canada-A synthesis of major deposit-types, district metallogeny, the evolution of geological provinces, and exploration methods: Geological Association of Canada Mineral Deposits Division Special Publication 5, p. 141-161.

Gaschnig, R.M., Vervoort, J.D., Lewis, R.S., and Tikoff, B., 2013, Probing for Proterozoic and Archean crust in the northern U.S. Cordillera with inherited zircon from the Idaho batholith: Geological Society of America Bulletin, v. 125; p. 73-88; doi:10.1130/B30583.1.

Gehrels, G.E., Johnsson, M.J., and Howell, D.G., 1999, Detrital zircon geochronology of the Adams Argillite and Nation River Formation, east-central Alaska, U.S.A.: Journal of Sedimentary Research, v. 69, p. 135-144.

Gehrels, G.E., and Berg, H.C., 1994, Geology of southeastern Alaska, in Plafker, George, and Berg, H.C., eds., The geology of Alaska: Geological Society of America Geology of North America, v. G-1, p. 451-468.

Gibbs, A.K., Payne, Barton, Setzer, Thomas, Brown, L.D., Oliver, J.E., and Kaufman, Sidney, 1984, Seismic reflection study of the Precambrian crust of central Minnesota: Geological Society of America Bulletin, v. 95, p. 280-294.

Giles, D., Betts, P., and Lister, G., 2002, Far-field continental backarc setting for the 1.80-1.67 Ga basins of northeastern Australia: Geology, v. 30, p. 823-826.

Gilman, Tony, Feineman, M., and Fisher, D., 2009, The Chulitna terrane of south-central Alaska-A rifted volcanic arc caught between the Wrangellia composite terrane and the Mesozoic margin of North America: Geological Society of America Bulletin, v. 121, p. 979-991.

Glen, J.M.G., Schmidt, J., Pellerin, L., McPhee, D.K., and O’Neill, J.M., 2007, Crustal structure of Wrangellia and adjacent terranes inferred from geophysical studies along a transect through the northern Talkeetna Mountains, in Ridgway, K.D., Trop, J.M., Glen, J.M.G., and O’Neill, J.M., eds., Tectonic growth of a collisional continental margin: Crustal evolution of southern Alaska: Geological Society of America Special Paper 431, p. 21-41.

Goodfellow, W.D., and Lydon, J.W., 2007, Sedimentary exhalative (SEDEX) deposits, in Goodfellow, W.D., ed., Mineral deposits of Canada-A synthesis of major deposit-types, district metallogeny, the evolution of geological provinces, and exploration methods: Geological Association of Canada, p. 163-184.

Goodfellow, W.D., Lydon, J.W.T., and Turner, R.J.W., 1993, Geology and genesis of stratiform sediment-hosted (SEDEX) zinc-lead-silver sulphide deposits, in Kirkham, R.V., and others, eds., Mineral deposit modeling: Geological Association of Canada Special Paper 40, p. 201-251. 
Goodge, J.W., and Vervoort, J.D., 2006, Origin of Mesoproterozoic A-type granites in Laurentia- $-\mathrm{Hf}$ isotope evidence: Earth and Planetary Science Letters, v. 243, p. 711-731.

Gorman, A.R., Clowes, R., Ellis, R., Henstock, T., Spence, G., Keller, G., Levander, A., Snelson, C., Burianyk, M., Kanasewich, E., Asudeh, I., Zoltan, H., and Miller, K., 2002, Deep Probe-Imaging the roots of western North America: Canadian Journal of Earth Sciences, v. 39, p. 375-398.

Graff, P.J., Sears, J.W., Holden, G.S., and Hausel, W.D., 1982, Geology of the Elmers Rock greenstone belt, Laramie Range, Wyoming: Geological Survey of Wyoming Report of Investigations 14, 23 p.

Grauch, V.J.S., Rodriguez, B.D., and Wooden, J.L., 2003, Geophysical and isotopic constraints on crustal structure related to mineral trends in north-central Nevada and implications for tectonic history: Economic Geology, v. 98, p. 269-286.

Gray, D.R., Foster, D.A., and Bierlein, F.P., 2002, Geodynamics and metallogeny of the Lachlan orogen: Australian Journal of Earth Science, v. 49, p. 1041-1056.

Gray, D.R., Foster, D.A., Maas, R., Spaggiari, C.V., Gregory, R.T., Goscombe, B., and Hoffmann, K.H., 2007, Continental growth and recycling by accretion of deformed turbidite fans and remnant ocean basins-Examples from Neoproterozoic and Phanerozoic orogens, in Hatcher, R.D., Jr., Carlson, M.P., McBride, J.H., and Martínez Catalán, J.R., eds., 4-D framework of continental crust: Geological Society of America Memoir 200, p. 63-92; doi: 10.1130/2007.1200(05).

Greene, A.R., Scoates, J.S., Weis, D., Katvala, E.C., Israel, S., and Nixon, G.T., 2010, The architecture of oceanic plateaus revealed by the volcanic stratigraphy of the accreted Wrangellia oceanic plateau: Geosphere, v. 6, p. 47-73.

Groves, D.I., and Bierlein, F.P., 2007, Geodynamic settings of mineral deposit systems: Geological Society [London] Journal, v. 164, p. 19-30.

Groves, D.I., Goldfarb, R.J., Gebre-Mariam, M., Hagemann, S.G., and Robert, F., 1998, Orogenic gold deposits-A proposed classification in the context of their crustal distribution and relationship to other gold deposit types: Ore Geology Reviews, v. 13, p. 7-27.

Groves, D.I., Bierlein, F.P., Meinert, L.D., and Hitzman, M.W., 2010, Iron oxide copper-gold (IOCG) deposits through earth history-Implications for origin, lithospheric setting, and distinction from other epigenetic iron oxide deposits: Economic Geology, v. 105, p. 641-654.

Gurney, J.J., Helmstaedt, H.H., Le Roux, A.P., Nowicki, T.E., Richardson, S.H., and Westerland, K.J., 2005, DiamondsCrustal distribution and formation processes in time and space and an integrated deposit model: Economic Geology 100th Anniversary Volume, p. 143-178.
Hacker, B.R., 1993, Evolution of the northern Sierra Nevada metamorphic belt - Petrological, structural, and $\mathrm{Ar} / \mathrm{Ar}$ constraints: Geological Society of America Bulletin, v. 105, p. 637-656.

Hacker, B.R., Kelemen, P.B., Rioux, M., McWilliams, M.O., Gans, P.B., Reiners, P.W., Layer, P.W., Söderlund, U., and Vervoort, J.D., 2011, Thermochronology of the Talkeetna intraoceanic arc of Alaska: $\mathrm{Ar} / \mathrm{Ar}, \mathrm{U}-\mathrm{Th} / \mathrm{He}$, Sm-Nd, and Lu-Hf dating: Tectonics, v. 30, TC1011; doi: 10.1029/2010TC002798.

Hacker, B.R., Mehl, L., Kelemen, P.B., Rioux, M., Behn, M.D., and Luffi, P., 2008, Reconstruction of the Talkeetna intraoceanic arc of Alaska through thermobarometry: Journal of Geophysical Research, v. 113, B03204; doi: 10.1029/2007JB005208

Hadley, J.B., 1970, The Ocoee Series and its possible correlatives, in Fisher, G.W., and others, eds., Studies of Appalachian geology - Central and southern: New York, Wiley Interscience, p. 247-259.

Hajnal, Zoltan, Ansdell, K.M., and Ashton, K.E., 2005, Introduction to special issue of Canadian Journal of Earth Sciences: The Trans-Hudson Orogen Transect of Lithoprobe: Canadian Journal of Earth Science, v. 42, p. 379-383; doi: 10.1139/E05-053.

Hamilton, Warren, 1998, Archean magmatism and deformation were not products of plate tectonics: Precambrian Research, v. 91, p. 143-179.

Hampton, B.A., Malkowski, M.A., and Deloge, J., 2009, Comparison and tentative correlation of Devonian-Triassic strata across tectonic terrane boundaries along the Denali fault, Alaska Range, southern Alaska [abs.]: Geological Society of America Abstracts with Programs, v. 41, no. 7, p. 301.

Hannington, M.D., de Ronde, C.E.J., and Petersen, S., 2005, Sea-floor tectonics and submarine hydrothermal systems, in Hedenquist, J.W., Thompson, J.F.H., Goldfarb, R.J., and Richards, J.P., eds., Economic Geology 100th Anniversary Volume, p. 111-141.

Hansen, V.L., and Dusel-Bacon, Cynthia, 1998, Structural and kinematic evolution of the Yukon-Tanana upland tectonites, east-central Alaska-A record of late Paleozoic to Mesozoic crustal assembly: Geological Society of America Bulletin, v. 110 , p. 211-230.

Harms, Tekla, Brady, J., Burger, H., and Cheney, J., 2004, Advances in the geology of the Tobacco Root Mountains, Montana, and their implications for the history of the northern Wyoming Province, in Brady, J.B., and others, eds., Precambrian geology of the Tobacco Root Mountains, Montana: Geological Society of America Special Paper 377, p. 227-243; doi: 10.1130/0-8137-2377-9.227. 
Harris, C.W., Gibson, R.G., Simpson, C., and Eriksson, K.A., 1987, Proterozoic cuspate basement-cover structure, Needle Mountains, Colorado: Geology, v. 15, p. 950-953.

Hatcher, R.D., Jr., 2010, The Appalachian orogen-A brief summary, in Tollo, R.P., Bartholomew, M.J., Hibbard, J.P., and Karabinos, P.M., eds., From Rodinia to Pangea-The lithotectonic record of the Appalachian region: Geological Society of America Memoir 206, p. 1-19.

Hausel, W.D., 1998, Diamonds and mantle source rocks in the Wyoming craton with a discussion of other U.S. occurrences: Wyoming State Geological Survey Report of Investigations 53, $93 \mathrm{p}$.

Hawkesworth, Chris, Dhuime, B., Pietranik, A., Cawood, P., Kemp, T., and Storey, C., 2010, The generation and evolution of the continental crust: Geological Society [London] Journal, v. 167, p. 229-248; doi: 10.1144/0016-76492009-072.

Heatherington, A.L., Mueller, P., and Wooden, J.L., 2010, Alleghanian plutonism in the Suwannee terrane, U.S.A.Implications for late Paleozoic tectonic models: Geological Society of America Memoir 206, p. 607-620.

Hedenquist, J.W., Thompson, J.F.H., Goldfarb, R.J., and Richards, J.P., eds., 2005, Economic Geology-100th Anniversary Volume, $1136 \mathrm{p}$.

Hibbard, J.P., van Staal, C.R., and Rankin, D.W., 2010, Comparative analysis of the geological evolution of the northern and southern Appalachian orogen-Late Ordovician-Permian, in Tollo, R.P., Bartholomew, M.J., Hibbard, J.P., and Karabinos, P.M., eds., From Rodinia to Pangea-The lithotectonic record of the Appalachian region: Geological Society of America Memoir 206, p. 51-69.

Hibbard, J.P., van Staal, C.R., Rankin, D.W., and Williams, H., 2006, Lithotectonic map of the Appalachian orogen, Canada-United States of America: Geological Survey of Canada Map 2096A, scale 1:1,500,000.

Hill, B.M., and Bickford, M.E., 2001, Paleoproterozoic rocks of central Colorado-Accreted arcs or extended older crust?: Geology, v. 29, p. 1015-1018; doi: 10.1130/00917613(2001) 029_1015:PROCCA_2.0.CO;2.

Hoare, J.M., 1961, Preliminary geology along the Lower Yukon River, Alaska: U.S. Geological Survey Open-File Report 61-64, scale 1:500,000.

Hoare, J.M., and Condon, W.H., 1962, Preliminary geologic map of the Lower Yukon-Norton Sound region, Alaska: U.S. Geological Survey Open-File Report 62-134, scale $1: 500,000$.

Hoffman, P.F., 1988, United plates of America, the birth of a craton-Early Proterozoic assembly and growth of Laurentia: Annual Reviews of Earth and Planetary Sciences: v. 16, p. 543-603.
Hoffman, P.F., 1991, Did the breakout of Laurentia turn Gondwanaland inside-out?: Science, v. 252, p. 1409-1412.

Hoffman, P.F., 1997, Tectonic genealogy of North America in Earth structure, in van der Pluijm, B.A., and Marshak, S., eds., An introduction to structural geology and tectonics: New York, McGraw-Hill, p. 459-464.

Holm, D.K., Anderson, R., Boerboom, T.J., Cannon, W.F., Chandler, V., Jirsa, M., Miller, J., Schneider, D.A., Schulz, K.J., and Van Schmus, W.R., 2007, Reinterpretation of Paleoproterozoic accretionary boundaries of the northcentral United States based on a new aeromagnetic-geologic compilation: Precambrian Research, v. 157, p. 71-79.

Holm, D.K., Van Schmus, W.R., MacNeill, L.C., Boerboom, T.J., Schweitzer, D., and Schneider, D., 2005, U-Pb zircon geochronology of Paleoproterozoic plutons from the northern midcontinent, USA-Evidence for subduction flip and continued convergence after geon 18 Penokean orogenesis: Geological Society of America Bulletin, v. 117, p. 259-275; doi: 10.1130/B25395.1.

Holm-Denoma, C.S., Hofstra, A.H., Noble, P.J., and Leslie, S.A., 2011, Paleozoic stratigraphy and kinematics of the Roberts Mountains allochthon in the Independence Mountains, northern Nevada, in Steininger, Roger, and Pennell, B., eds., Great Basin evolution and metallogeny: Geological Society of Nevada 2010 Symposium, Reno, Nev., Proceedings, p. 1039-1054.

Horton, J.W., Jr., Drake, A.A., Jr., and Rankin, D.W., 1989, Tectonostratigraphic terranes and their Paleozoic boundaries in the central and southern Appalachians, in Dallmeyer, R.D., ed., Terranes in the Circum-Atlantic Paleozoic orogens: Geological Society of America Special Paper 230, p. 213-245.

Horton, J.W., Jr., Aleinikoff, J.N., Drake, A.A., Jr., and Fanning, C.M., 2010, Ordovician volcanic-arc terrane in the central Appalachian Piedmont of Maryland and VirginiaSHRIMP U-Pb geochronology, field relations, and tectonic significance, in Tollo, R.P., Bartholomew, M.J., Hibbard, J.P., and Karabinos, P.M., eds., From Rodinia to PangeaThe lithotectonic record of the Appalachian region: Geological Society of America Memoir 206, p. 621-660.

Jahn, B.-M., Glikson, A.Y., Peucat, J.J., and Hickman, A.H., 1981, REE geochemistry and isotopic data of Archaean silicic volcanics and granitoids from the Pilbara block, Western Australia - Implications for the early crustal evolution: Geochimica et Cosmochimica Acta, v. 45, p. 16331652; doi: 10.1016/S0016-7037(81)80002-6.

John, D.A., Ayuso, R.A., Barton, M.D., Blakely, R.J., Bodnar, R.J., Dilles, J.H., Gray, Floyd, Graybeal, F.T., Mars, J.C., McPhee, D.K., Seal, R.R., Taylor, R.D., and Vikre, P.G., 2010, Porphyry copper deposit model, chap. B of Mineral deposit models for resource assessment: U.S. Geological Survey Scientific Investigations Report 2010-5070-B, 169 p; http://pubs.usgs.gov/sir/2010/5070/b/. 
Jones, D.S., Barnes, C.G., Premo, W.R., and Snoke, A.W., 2013, Reactivation of the Archean-Proterozoic suture along the southern margin of Laurentia during the Mazatzal orogenyPetrogenesis and tectonic implications of ca. 1.63 Ga granite in southeastern Wyoming: Geological Society of America Bulletin, v. 125, p. 164-183; doi: 10.1130/B30577.1.

Jones, J.V., III, Connelly, J.N., Karlstrom, K.E., Williams, M.L., and Doe, M.F., 2009, Age, provenance, and tectonic setting of Paleoproterozoic quartzite successions in the southwestern United States: Geological Society of America Bulletin, v. 121, p. 247-264.

Jones, J.V., III, Sidoway, C.S., and Connelly, J.N., 2010, Characteristics and implications of ca. $1.4 \mathrm{Ga}$ deformation across a Proterozoic mid-crustal section, Wet Mountains, Colorado, USA: Lithosphere, v. 2, p. 119-135; doi: 10.1130/L78.1.

Karlstrom, K.E., and Humphries, E.D., 1998, Persistent influence of Proterozoic accretionary boundaries in the tectonic evolution of southwestern North America-Interaction of cratonic grain and mantle modification events: Rocky Mountain Geology, v. 33, p. 161-179.

Karlstrom, K.E., and Williams, M.L., 2006, Nature of the middle crust-Heterogeneity of structure and process due to pluton-enhanced tectonism, an example from Proterozoic rocks of the North American Southwest, in Brown, Michael, and Rushmere, T., eds., Evolution and differentiation of the continental crust: Cambridge, U.K., Cambridge University Press, p. 268-295.

Kearey, Phillip, Klepeis, K.A., and Vine, F.J., 2009, Global tectonics: West-Sussex, U.K., Wiley-Blackwell, 482, p.

Kellogg, K.S., Snee, L.W., and Unruh, D.M., 2003, The Mesoproterozoic Beaverhead impact structure and its tectonic setting, Montana-Idaho- ${ }^{40} \mathrm{Ar} /{ }^{39} \mathrm{Ar}$ and $\mathrm{U}-\mathrm{Pb}$ isotopic constraints: Journal of Geology, v. 111, p. 639-652; http://www. jstor.org/stable/10.1086/378339.

Keppie, J.D., and Ramos, V.A., 1999, Odyssey of terranes in the Iapetus and Rheic oceans during the Paleozoic, in Ramos, V.A., and Keppie, J.D., eds., Laurentia-Gondwana connections before Pangea: Geological Society of America Special Paper 336, p. 267-276.

Klein, T.L., and Sims, P.K., 2007, Control of epigenetic metal deposits by Paleoproterozoic basement architecture, in Lund, Karen, ed., Earth science studies in support of public policy development and land stewardship_-Headwaters province, Idaho and Montana, U.S. Geological Circular 1305, p. 17-26.

Leach, D.L., Sangster, D.F., Kelley, K.D., Large, R.R., Garven, G., Allen, C.R., Gutzmer, J., and Walters, S., 2005, Sediment-hosted lead-zinc deposits-A global perspective, in Hedenquist, J.W., and others, eds., Economic Geology 100th Anniversary Volume p. 561-607.
Leahy, Kevin, Barnicoat, A.C., Foster, R.P., Lawrence, S.R., and Napier, R.W., 2005, Geodynamic processes that control the global distribution of giant gold deposits: in McDonald, Iain, Boyce, A.J., Butler, I.B., Herrington, R.J., and Polya, D.A., eds., Mineral deposits and earth evolution, Geological Society [London] Special Publications, 248, p. 119-132.

Leeman, W.P., Menzies, M.A., Matty, D.J., and Embree, G.F., 1985, Strontium, neodymium and lead isotopic compositions of deep crustal xenoliths from the Snake River Plain-Evidence for Archean basement: Earth and Planetary Science Letters, v. 75, p. 354-368.

Lemieux, Sophie, Ross, G.M., and Cook, F.A., 2000, Crustal geometry and tectonic evolution of the Archean crystalline basement beneath the southern Alberta Plains, from new seismic reflection and potential-field studies: Canadian Journal of Earth Sciences, v. 37, p 1437-1491.

Lewis, R.S., Brewer, R.A., Jansen, A.C., Guevara, V.E., Vervoort, J.D., and Baldwin, J.A., 2011, Below the Belt-A road log of Archean and Paleoproterozoic rocks in the eastern Clearwater complex, Idaho: Northwest Geology, v. 40, p. $143-157$.

Lewis, R.S., Vervoort, J.D., Burmester, R.F., McClelland, W.C., and Chang, Z., 2007, Geochronological constraints on Mesoproterozoic and Neoproteroic(?) high-grade metasedimentary rocks of north-central Idaho, U.S.A., in Link, P.K., and Lewis, R.S., eds., Proterozoic geology of western North America and Siberia: Society for Sedimentary Geology Special Publication 86, p. 37-53.

Loewy, S.L., Connelly, J.N., Dalziel, I.W.D., and Gower, C., 2003, Eastern Laurentia in Rodinia - Constraints from whole-rock $\mathrm{Pb}$ and $\mathrm{U} / \mathrm{Pb}$ geochronology: Tectonophysics, v. 375, p. 169-197.

Long, K.R., DeYoung, J.H., Jr., and Ludington, S.D., 1998, Database of significant deposits of gold, silver, copper, lead, and zinc in the United States: U.S. Geological Survey Open-File Report 98-206 A,B, 33 p. http://pubs.usgs.gov/ of/1998/0206a-b/.

Lund, Karen, 2008, Geometry of the Neoproterozoic and Paleozoic rift margin of western Laurentia-Implications for mineral deposit settings: Geosphere, v. 4, p. 429-444; doi: $10.1130 / \mathrm{GES} 00121.1$.

Lund, Karen, Aleinikoff, J.N., Yacob, E.Y., Unruh, D.M., and Fanning, C.M., 2008, Coolwater culmination-Sensitive high-resolution ion microprobe(SHRIMP) U-Pb and isotopic evidence for continental delamination in the Syringa embayment, Salmon River suture, Idaho: Tectonics v. 27, doi:10.1029/2006TC002071.

Marlow, M.S., and Cooper, A.K., 1980, Mesozoic and Cenozoic structural trends beneath the southern Bering Sea shelf: American Association of Petroleum Geologists Bulletin, v. 64, p. 2139-2155. 
Mattinson, J.M., and James, E.W., 1985, Salinian block U-Pb age and isotopic variations-Implications for origin and emplacement of the Salinian terrane, in Howell, D.G., ed., Tectonostratigraphic terranes of the CircumPacific region: Circum-Pacific Council Energy Mineral Resources, Earth Science Series 1, p. 215-226.

McLaughlin, R.J., Kling, S.A., Poore, R.Z., McDougall, K., and Beutner, E.C., 1982, Post-middle Miocene accretion of Franciscan rocks, northwestern California: Geological Society of America Bulletin: v. 93, p. 595-605.

McLelland, J.M., Daly, S.J., and Chiarenzelli, J., 1993, $\mathrm{Sm}-\mathrm{Nd}$ and $\mathrm{U}-\mathrm{Pb}$ isotopic evidence of juvenile crust in the Adirondack lowlands and implications for the evolution of the Adirondack Mountains: Journal of Geology, v. 101, p. $97-105$.

McClelland, W.C., Kusky, T., Bradley, D.C., Dumoulin, J., and Harris, A.G., 1999, The nature of Nixon Fork "basement," west-central Alaska [abs.]: Geological Society of America Abstracts with Programs, v. 31, no. 6, p. 78.

McCormick, K.A., 2010, Precambrian basement terrane of South Dakota: South Dakota Department of Environmental and Natural Resources Bulletin 41, 45 p.

Miller, M.L., Bradley, D.C., Bundtzen, T.K., Blodgett, R.B., Pessagno, E.A., Jr., Tucker, R.D., and Harris, A.G., 2007, The restricted Gemuk Group-A Triassic to Lower Cretaceous succession in southwestern Alaska, in Ridgway, K.D., Trop, J.M., Glen, J.M.G., and O’Neill, J.M., eds., Tectonic growth of a collisional continental margin: Crustal evolution of southern Alaska: Geological Society of America Special Paper 431, p. 273-305.

Miller, M.L., Bradshaw, J.Y., Kimbrough, D.L., Stern, T.W., and Bundtzen, T.K., 1991, Isotopic evidence for early Proterozoic age of the Idono complex, west-central Alaska: Journal of Geology, v. 99, p. 209-223.

Moll-Stalcup, E.J., and Arth, J.G., 1989, The nature of the crust in the Yukon-Koyukuk province as inferred from the chemical and isotopic composition of five Late Cretaceous to early Tertiary volcanic fields in western Alaska: Journal of Geophysical Research, v. 94, no. B11, p. 15,989-16,002.

Moll-Stalcup, E.J., Wooden, J.L., Bradshaw, J., and Aleinikoff, J.N., 1996, Elemental and isotopic evidence for 2.1-Ga arc magmatism in the Kilbuck terrane, southwestern Alaska, in Moore, T.E., and Dumoulin, J.A., eds., Geologic studies in Alaska by the U.S. Geological Survey in 1994, U.S. Geological Survey Bulletin 2152, p. 111-130.

Moore, T.E., and Nokleberg, W.J., 1988, Stratigraphy, sedimentology, and structure of the Wickersham terrane in the Cache Mountain area, east-central Alaska, in Galloway, J.P., and Hamilton, T.D., eds., Geologic studies in Alaska by the U.S. Geological Survey during 1987: U.S. Geological Survey Circular 1016, p. 75-80.
Moore, T.E., Wallace, W.K., Bird, K.J., Karl, S.M., Mull, C.G., and Dillon, J.T., 1994, Geology of northern Alaska, in Plafker, George, and Berg, H.C., eds., The geology of Alaska: Geological Society of America Geology of North America, v. G-1, p. 49-140.

Moore, T.E., Wallace, W.K., Mull, C.G., Adams, K.E., Plafker, G., and Nokleberg, W.J., 1997, Crustal implications of bedrock geology along the Trans-Alaska Crustal Transect (TACT) in the Brooks Range, northern Alaska: Journal of Geophysical Research, v. 102, p. 20,645-20,684.

Mosher, Sharon, 1998, Tectonic evolution of the southern Laurentian Grenville orogenic belt: Geological Society of America Bulletin, v. 110, p. 1357-1375.

Mosier, D.L., Berger, V.I., and Singer, D.A., 2009, Volcanogenic massive sulfide deposits of the world-Database and grade and tonnage models: U.S. Geological Survey Open-File Report 2009-1034, 46 p.; http://pubs.usgs.gov/ of/2009/1034/.

Mosier, D.L., Singer, D.A., Moring, B.C., and Galloway, J.P., 2012, Podiform chromite deposits - Database and grade and tonnage models: U.S. Geological Survey Scientific Investigations Report 2012-5157, 45 p. and database; http://pubs. usgs.gov/sir/2012/5157/.

Mueller, P.A., Burger, H.R., Wooden, J.L., Brady, J.B., Cheney, J.T., Harms, T.A., Heatherington, A.L., and Mogk, D.W., 2005, Paleoproterozoic metamorphism in the northern Wyoming Province-Implications for the assembly of Laurentia: The Journal of Geology, v. 113, p. 169-179.

Mueller, P.A., Burger, H.R., Wooden, J.L., Heatherington, A.L., Mogk, D.W., and D'Arcy, K., 2004, Age and evolution of the Precambrian crust of the Tobacco Root Mountains, in Brady, John, and others, eds., Precambrian geology of the Tobacco Root Mountains, Montana: Geological Society of America Special Paper 377, p. 181-202.

Mueller, P.A., and Frost, C.D., 2006, The Wyoming ProvinceA distinctive Archean craton in Laurentian North America: Canadian Journal of Earth Sciences, v. 43, p. 1391-1397.

Mueller, P.A., Heatherington, A.L., Kelly, D.M., Wooden, J.L., and Mogk, D.W., 2002, Paleoproterozioc crust within the Great Falls tectonic zone-Implications for the assembly of southern Laurentia: Geology, v. 30, p. 127-130; doi: 10.1130/0091 7613(2002)030<0127:PCWTGF>2.0.CO;2.

Mueller, P.A., Shuster, R.D., D’Arcy, K.A., Heatherington, A.L., Nutman, A.P., and Williams, I.S., 1995, Source of the northeastern Idaho batholith-Isotopic evidence for a Paleoproterozoic terrane in the northwestern U.S.: The Journal of Geology, v. 103, n. 1, p. 63-72; doi: 10.1086/629722.

Mueller, P.A., Wooden, J.L., Mogk, D.W., and Foster, D.A., 2011, Paleoproterozoic evolution of the Farmington zoneImplications for terrane accretion in southwestern Laurentia: Lithosphere, v. 3, p. 401-408. 
Nagel, T.J., Hoffmann, J.E., and Muncher, C., 2012, Generation of Eoarchean tonalite-trondhjemite-granodiorite from thickened mafic arc crust: Geology, v. 40, p. 375-378.

Nance, R.D., Murphy, J.B., and Santosh, M., 2014, The supercontinent cycle-A retrospective essay: Gondwana Research, v. 25, p. 4-29; http://dx.doi.org/10.1016/j. gr.2012.12.026.

Nelson, S.T., Hart, G.L., and Frost, C.D., 2011, A reassessment of Mojavia and a new Cheyenne Belt alignment in the eastern Great Basin: Geosphere; v. 7, p. 513-527; doi: 10.1130/GES00595.1.

Nicholson, S.W., Cannon, W.F., and Schulz, K.J., 1992, Metallogeny of the midcontinent rift system of North America: Precambrian Research, v. 58, p. 355-386.

Nokleberg, W.J., Plafker, G., and Wilson, F.H., 1994, Geology of south-central Alaska: in Plafker, George, and Berg, H.C., eds., The geology of Alaska: Geological Society of America Geology of North America, v. G-1, p. 311-366.

Nokleberg, W.J., and Richter, D.H., 2007, Origin of narrow terranes and adjacent major terranes occurring along the Denali fault in the eastern and central Alaska Range, Alaska: in Ridgway, K.D., Trop, J.M., Glen, J.M.G., and O'Neill, J.M., eds., Tectonic growth of a collisional continental margin - Crustal evolution of southern Alaska: Geological Society of America Special Paper 431, p. 129-154.

North American Magnetic Anomaly Group (NAMAG)_-Viki Bankey, Alejandro Cuevas, David Daniels, Carol A. Finn, Israel Hernandez, Patricia Hill, Robert Kucks, W. Miles, Mark Pilkington, Carter Roberts, Victoria Rystrom, Sarah Shearer, Steven Snyder, Ron Sweeney, and Julio Velez), 2002, Magnetic anomaly map of North America: U.S. Geological Survey Special Map.

Northrup, C.J., Schmitz, M., Kurz, G., and Tumpane, K., 2011, Tectonomagmatic evolution of distinct arc terranes in the Blue Mountains Province, Oregon and Idaho: Geological Society of America Field Guide, v. 21, p. 67-88.

O’Neill, J.M., and Lopez, D., 1985, Character and regional significance of Great Falls tectonic zone, east-central Idaho and west-central Montana: American Association of Petroleum Geologists Bulletin, v. 69, p. 437-447.

Parsons, Tom, Wells, R.E., Fisher, M.A., Fleuh, E., and ten Brink, U.S., 1999, Three-dimensional velocity structure of Siletzia and other accreted terranes in the Cascadia forearc of Washington: Journal of Geophysical Research, v. 104, no. B8, p. 18,015-18,039.

Patchett, P.J., and Ruiz, J., 1989, Nd isotopes and the origin of Grenville-aged rocks in Texas-Implications for Proterozoic evolution of the United States midcontinent region: Journal of Geology, v. 97, p. 685-695.
Patton, W.W., Jr., and Box, S.E., 1989, Tectonic setting of the Yukon-Koyukuk basin and its borderlands, western Alaska: Journal of Geophysical Research, v. 94, n. B11, p.15,807-15,820.

Patton, W.W., Jr., and Moll-Stalcup, E.J., 1996, Geologic map of the Unalakleet quadrangle, west-central Alaska: U.S. Geological Survey Miscellaneous Investigations Map I-2559, scale 1:250,000, 39 p.

Patton, W.W., Jr., Wilson, F.H., Labay, K.A., and Shew, N., 2009, Geologic map of the Yukon-Koyukuk basin, Alaska: U.S. Geological Survey Scientific Investigations Map 2909, scale $1: 250,000,26 \mathrm{p}$.

Petit, Charles, 2010, Continental hearts: Science News, v. 178, p. $22-26$.

Petrascheck, W.E., 1965, Typical features of metallogenic provinces: Economic Geology, v. 60, p. 1620-1634.

Petrascheck, W.E., 1969, Ore metals from the crust or mantle: Economic Geology, v. 64, p. 576-578.

Piercey, S.J., and Colpron, M., 2009, Composition and provenance of the Snowcap assemblage, basement to the Yukon-Tanana terrane, northern Cordillera: Implications for Cordilleran crustal growth, Geosphere, v. 5, p. 439-464.

Pilkington, Mark, and Saltus, R.W., 2007, The Mackenzie River magnetic anomaly, Yukon and Northwest Territories, Canada_Evidence for Early Proterozoic magmatic arc crust at the edge of the North American craton: Tectonophysics, v. 478, p. 78-86.

Piranjno, Franco, 2000, Ore deposits and mantle plumes: Dordrecht, The Netherlands, Kluwer Academic Press, 559 p.

Plafker, George, Moore, J.C., and Winkler, G.R., 1994, Geology of the southern Alaska margin, in Plafker, George, and Berg, H.C., eds., The geology of Alaska: Geological Society of America Geology of North America, v. G-1, p. 389-450.

Polat, Ali, 2012, Growth of Archean continental crust in oceanic island arcs: Geology, v. 40, p. 383-384; doi: 10.1130/ focus042012.1.

Pollack, H.N., 1986, Cratonization and thermal evolution of the mantle: Earth and Planetary Science Letters, v. 80, p. 175-182.

Poole, F.G., Perry, W.J., Jr., Madrid, R.J., and AmayaMartínez, R., 2005, Tectonic synthesis of the OuachitaMarathon-Sonora orogenic margin of southern LaurentiaStratigraphic and structural implications for timing of deformational events and plate-tectonic model, in Anderson, T.H., Nourse, J.A., McKee, J.W., and Steiner, M.B., eds., The Mojave-Sonora megashear hypothesis-Development, assessment, and alternatives: Geological Society of America Special Paper 393, p. 543-596; doi: 10.1130/2005.2393(21). 
Reed, B.L., and Lanphere, M.A., 1973, The Alaska-Aleutian Range batholith - Geochronology, chemistry, and relation to Circum-Pacific plutonism: Geological Society of America Bulletin, v. 84, p. 2583-2610.

Roback, R.C., and Walker, N.W., 1995, Provenance, detrital zircon $\mathrm{U}-\mathrm{Pb}$ geochronometry, and tectonic significance of Permian to Lower Triassic sandstone in southeastern Quesnellia, British Columbia and Washington: Geological Society of America Bulletin, v. 107, p. 665-675.

Rodriguez, B.D., and Williams, J.M., 2008, Tracking the Archean-Proterozoic suture zone in the northeastern Great Basin, Nevada and Utah: Geosphere, v. 4, p. 315-328; doi: 10.1130/GES00120.1.

Roeske, S.M., Dusel-Bacon, C., Aleinikoff, J.N., Snee, L.W., and Lanphere, M.A., 1995, Metamorphic and structural history of continental crust at a Mesozoic collisional margin, the Ruby terrane, central Alaska: Journal of Metamorphic Geology, v. 13, p. 25-40.

Roeske, S.M., McClelland, W.C., and Bradley, D.C., 2006, Ruby terrane, north-central Alaska - Composite of continental affinity rocks [abs.]: Geological Society of America Abstracts with Programs, v. 38, no. 5, p. 12.

Rollinson, Hugh, 2010, Coupled evolution of Archean continental crust and subcontinental lithospheric mantle: Geology, v. 38, p. 1083-1086; doi: 10.1130/G31159.1.

Ross, G.M., 2002, Evolution of Precambrian continental lithosphere in western Canada-Results from Lithoprobe studies in Alberta and beyond: Canadian Journal of Earth Sciences, v. 39, p. 413-437; doi: 10.1139/e02-012.

Ross, G.M., Parrish, R.R., Villeneuve, M.E., and Bowring, S.A., 1991, Geophysics and geochronology of the crystalline basement of the Alberta Basin, western Canada: Canadian Journal of Earth Sciences, v. 28, p. 512-522.

Rostad, O.H., 1978, K-Ar dates for mineralization in the White Cloud-Cannivan porphyry molybdenum belt of Idaho and Montana-A discussion: Economic Geology, v. 73 , p. $1366-1368$.

Rubin, C.M., and Saleeby, J.B., 1991, Tectonic framework of the upper Paleozoic and lower Mesozoic Alava sequenceA revised view of the polygenetic Taku terrane in southern southeast Alaska: Canadian Journal of Earth Sciences, v. 28, p. $881-893$.

Rudnick, R.L., and Gao, S., 2003, Composition of the continental crust, in Rudnick, R.L., ed., The crust: Oxford, U.K., Elsevier-Pergamon, v. 3, p. 1-64; ISBN 0-08-043751-6.

Saleeby, J.B., 1982, Polygenetic ophiolite belt of the California Sierra Nevada-Geochronological and tectonostratigraphic development: Journal of Geophysical Research, v. 87 , p. $1803-1824$.
Saltus, R.W., and Hudson, T.L., 2007, Regional magnetic anomalies, crustal strength, and the location of the northern Cordilleran fold-and-thrust belt: Geology, v. 35, p. 567-570.

Saltus, R.W., Potter, C.J., and Phillips, J.D., 2006, Crustal insights from gravity and aeromagnetic analysis-Central North Slope, Alaska: American Association of Petroleum Geologists Bulletin, v. 90, p. 1495-1517.

Samson, S.D., McClelland, W.C., Patchett, P.J., Gehrels, G.E., Anderson, R.G., and others, 1989, Evidence from neodymium isotopes for mantle contributions to Phanerozoic crustal genesis in the Canadian Cordillera: Nature, v. 337, p. 705-709.

Samson, S.D., Patchett, P.J., McClelland, W.C., and Gehrels, G.E., 1991, Nd isotopic characterization of metamorphic rocks in the Coast Mountains, Alaskan and Canadian Cordillera-Ancient crust bounded by juvenile terranes: Tectonics, v. 10, p. 770-780.

Schmandt, Brandon, and Humphreys, E.D., 2011, Seismically imaged relict slab from the $55 \mathrm{Ma}$ Siletzia accretion to northwest USA: Geology, v. 39, p. 175-178.

Schmitz, M.D., Bowring, S.A., Southwick, D.L., Boerboom, T.J., and Wirth, K.R., 2006, High-precision U-Pb geochronology in the Minnesota River Valley subprovince and its bearing on the Neoarchean to Paleoproterozoic evolution of the southern Superior Province: Geological Society of America Bulletin, v. 118, p. 82-93; doi: 10.1130/B25725.1.

Schneider, D.A., Heizler, M.T., Bickford, M.E., Wortman, G.L., Condie, K.C., and Perilli, S., 2007, Timing constraints of orogeny to cratonization-Thermochronology of the Paleoproterozoic Trans-Hudson orogen, Manitoba and Saskatchewan, Canada: Precambrian Research, v. 153, p. 65-95.

Schruben, Paul, recompiler, 2002, Assessment of undiscovered deposits of gold, silver, copper, lead, and zinc in the United States, a portable document (PDF) recompilation of USGS Open-File Report 96-96 and Circular 1178: U.S. Geological Survey Open-File Report OF-02-198.

Schulte, R.F., Taylor, R.D., Piatak, N.M., and Seal, R.R., II, 2012, Stratiform chromite deposit model, Chap. E in Shanks, W.C., III, and Thurston, Roland, eds., Mineral deposit models for resource assessment: U.S. Geological Survey Scientific Investigations Report 2010-5070-E, $131 \mathrm{p}$.

Schulz, K.J., Chandler, V.W., Nicholson, S.W., Piatak, Nadine, Seal, R.R., II, Woodruff, L.G., and Zientek, M.L., 2010, Magmatic sulfide-rich nickel-copper deposits related to picrite and (or) tholeiitic basalt dike-sill complexesA preliminary deposit model: U.S. Geological Survey Open-File Report 2010-1179, 25 p; http://pubs.usgs.gov/ of/2010/1179/. 
Shanks, W.C. Pat, III, and Thurston, Roland, eds., 2012, Volcanogenic massive sulfide occurrence model: U.S. Geological Survey Scientific Investigations Report 2010-5070-C, $345 \mathrm{p}$.

Shaulis, B.J., Lapen, T.J., Casey, J.F., and Reid, D.R., 2012, Timing and rates of flysch sedimentation in the Stanley Group, Ouachita Mountains, Oklahoma and Arkansas, U.S.A.-Constraints from U-Pb zircon ages of subaqueous ash-flow tuffs: Journal of Sedimentary Research, v. 82, p. $833-840$.

Shaw, C.A., Heizler, M.T., and Karlstrom, K.E., 2005, ${ }^{40} \mathrm{Ar} /{ }^{30} \mathrm{Ar}$ thermochronologic record of $1.45-1.35 \mathrm{Ga}$ intracontinental tectonism in the southern Rocky Mountains-Interplay of conductive and advective heating with intracontinental deformation, in Karlstrom, K.E., and Keller, G.R., eds., The Rocky Mountain region-An evolving lithosphere: American Geophysical Union Geophysical Monograph 154, p. 163-184.

Shervais, J.W., 2006, The significance of subduction-related accretionary complexes in early Earth processes Geological Society of America Special Papers, v. 405, p. 173-192; doi: 10.1130/2006.2405(10).

Shervais, J.W., Murchey, B.L., Kimbrough, D.L., Renne, P.R., and Hanan, B., 2005, Radioisotopic and biostratigraphic age relations in the Coast Range ophiolite, northern California-Implications for the tectonic evolution of the western Cordillera: Geological Society of America Bulletin, v. 117, p. 633-653.

Silberling, N.J., Jones, D.L., Monger, J.W.H., and Coney, P.J., 1992, Lithotectonic terrane map of the North American Cordillera: U.S. Geological Survey Miscellaneous Investigations Series Map I-2176, scale 1:5,000,000.

Simmons, S.F., White, N.C., and John, D.A., 2005, Geological characteristics of epithermal precious and base-metal deposits: Economic Geology 100th Anniversary Volume, p. $485-522$.

Sims, P.K., 1990, Precambrian basement map of the northern midcontinent, U.S.A.: U.S. Geological Survey IMAP 1853-A, scale 1:1,000,000, $10 \mathrm{p}$.

Sims, P.K., 1990, Precambrian basement map of the northern Midcontinent USA: U.S. Geological Survey Miscellaneous Investigations Series Map I-1853-A, scale 1:1,000,000.

Sims, P.K., Kisvarsanyi, E.B., and Morey, G.B., 1987, Geology and metallogeny of Archean and Proterozoic basement terranes in the northern midcontinent, U.S.A.-An overview: U.S. Geological Survey Bulletin 1815, 51 p.

Sims, P.K., Lund, K., and Anderson, E.D., 2005, Precambrian crystalline basement map of Idaho-An interpretation of geomagnetic data: U.S. Geological Survey Scientific Investigations Map 2829, scale 1:1,000,000.
Sims, P.K., and Peterman, Z.E., 1986, Early Proterozoic Central Plains orogen-A major buried structure in the northcentral United States: Geology, v. 14, p. 488-491.

Sims, P.K., Peterman, Z.E., Hildenbrand, T.G., and Mahan, S., 1991, Precambrian basement map of the Trans-Hudson orogen and adjacent terranes, northern Great Plains, U.S.A.: U.S. Geological Survey Miscellaneous Investigations Series Map I-2214, 53 p., 1 map sheet, scale 1:1,000,000.

Sims, P.K., Saltus, R.W., and Anderson, E.D., 2008, Precambrian basement structure map of the continental United States - An interpretation of geologic and aeromagnetic data: U.S. Geological Survey Scientific Investigations Map 3012, scale: 1:8,000,000.

Singer, D.A., Page, N.J., and Lipin, B.R., 1986, Grade and tonnage model of major podiform chromite, in Cox, D.P., and Singer, D.A., eds., Mineral deposit models: U.S. Geological Survey Bulletin 1693, p. 38-44.

Snow, C.A., and Scherer, H., 2006, Terranes of the Western Sierra Nevada Foothills metamorphic belt, California: A critical review: International Geology Review, v. 48, p. 46-62.

Snow, C.A., Wakabayashi, J., Ernst, W.G., and Wooden, J.L., 2010, Detrital zircon evidence for progressive underthrusting in Franciscan metagraywackes, west-central California: Geological Society of America Bulletin, v. 122, p. 282-291.

Stanley, R.S., and Ratcliffe, N.M., 1985, Tectonic synthesis of the Taconian orogeny in western New England: Geological Society of America Bulletin, v. 96, p. 1227-1250.

Stewart, R.J., and Brandon, M.T., 2004, Detrital-zircon fission-track ages for the 'Hoh Formation'-Implications for late Cenozoic evolution of the Cascadia subduction wedge: Geological Society of America Bulletin, v. 116, p. 60-75.

Strickland, Ariel, Miller, E.L., and Wooden, J.L., 2011, The timing of Tertiary metamorphism and deformation in the AlbionRaft River-Grouse Creek metamorphic core complex, Utah and Idaho: Journal of Geology, v. 119, p. 185-206.

Taylor, R.D., Hammarstrom, J.M., Piatak, N.M., and Seal, R.R., II, 2012, Arc-related porphyry molybdenum deposit model, chap. D of Mineral deposit models for resource assessment: U.S. Geological Survey Scientific Investigations Report 2010-5070-D, 64 p; http://pubs.usgs.gov/ sir/2010/5070/d/.

Thomas, W.A., 1991, The Appalachian-Ouachita rifted margin of southeastern North America: Geological Society of America Bulletin, v. 103, no. 3, p. 415-431.

Thomas, W.A., 2010, Interactions between the southern Appalachian-Ouachita orogenic belt and basement faults in the orogenic footwall and foreland, in Tollo, R.P., Bartholomew, M.J., Hibbard, J.P., and Karabinos, P.M., eds., From Rodinia to Pangea - The lithotectonic record of the Appalachian region: Geological Society of America Memoir 206, p. 897-916. 
Till, A.B., Dumoulin, J.A., Harris, A.G., Moore, T.E., Bleick, H.A., and Siwiec, B.R., 2008, Bedrock geologic map of the southern Brooks Range, Alaska, and accompanying conodont data: U.S. Geological Survey Open-File Report 2008-1149, scale 1:250,000, 88 p.

Till, A.B., Dumoulin, J.A., Phillips, J.D., Stanley, R.G., and Crews, J.M., 2006, Generalized bedrock geologic map, Yukon Flats region, east-central Alaska: U.S. Geological Survey Open-File Report 2006-1304, scale 1:500,000, 25 p.

Till, A.B., Dumoulin, J.A., Werdon, M.B., and Bleick, H.A., 2011, Bedrock geologic map of the Seward Peninsula, Alaska, and accompanying conodont data: U.S. Geological Survey Scientific Investigations Map 3131, 2 sheets, scale 1:500,000, 1 pamphlet, 75 p., and database, available at http://pubs.usgs.gov/sim/3131/.

Titley, S.R., 2001, Crustal affinities of metallogenesis in the American southwest: Economic Geology, v. 96, p.1323-1342.

Tohver, Eric, Bettencourt, J.S., Tosdal, R., Mezger, K., Leite, W.B., and Payolla, B.L., 2004, Terrane transfer during the Grenville orogeny-Tracing the Amazonian ancestry of southern Appalachian basement through $\mathrm{Pb}$ and Nd isotopes: Earth and Planetary Science Letters, v. 228, p. 185-200; doi: 10.1016/S0012-821 X(02)00561-7.

Tooker, E.W., 1983, Correlation of metal occurrence and terrane attributes in the northwestern conterminous United States: Canadian Journal of Earth Sciences, v. 20, p.10301039. doi: 10.1139/e83-093.

Tosdal, R.M., Wooden, J.L., and Kistler, R.W., 2000, Inheritance of Nevadan mineral belts from Neoproterozoic continental breakup, in Cluer, J.K., Price, J.G., Struhsacker, E.M., Hardyman, R.F., and Morris, C.L., eds., Geology and ore deposits 2000 - The Great Basin and Beyond: Geological Society of Nevada Symposium Proceedings, 15-18 May 2000: Reno, Nevada, Geological Society of Nevada, p. 451-466.

Tréhu, A.M., Asudeh, I., Brocher, T.M., Luetgert, J.H., Mooney, W.D., Nabelek, J.L., and Nakamura, Y., 1994, Crustal architecture of the Cascadia forearc: Science, New Series, v. 266, no. 5183, p. 237-243.

Tréhu, A.M., Blakely, R.J., and Williams, M.C., 2012, Subducted seamounts and recent earthquakes beneath the central Cascadia forearc: Geology, v. 40, p. 103-106.

Tull, J.F., Holm-Denoma, C.S., and Barineau, C.I., 2014, Early to Middle Ordovician back-arc basin in the southern Appalachian Blue Ridge: Characteristics, extent, and tectonic significance: Geological Society of American Bulletin, v. 126, p. 990-1015, doi:10.1130/B30967.1.

Tweto, Ogden, and Sims, P.K., 1963, Precambrian ancestry of the Colorado mineral belt: Geological Society of America Bulletin, v. 74, p. 991-1014.
Unterschutz, J.L., Creaser, R.A., Erdmer, P., Thompson, R.I., and Daughtry, K.L., 2002, North American margin origin of Quesnel terrane strata in the southern Canadian Cordillera-Inferences from geochemical and $\mathrm{Nd}$ isotopic characteristics of Triassic metasedimentary rocks: Geological Society of America Bulletin, v. 114, p. 462-475.

Vallier, T.L., 1995, Petrology of pre-Tertiary igneous rocks in the Blue Mountains region of Oregon, Idaho, and Washington: Implications for the geologic evolution of a complex island arc, in Vallier, T.L., and Brooks, H.C., eds., Geology of the Blue Mountains region of Oregon, Idaho, and Washington-Petrology and tectonic evolution of pre-Tertiary Rocks of the Blue Mountains region: U.S. Geological Survey Professional Paper 1438, p. 125-209.

Van Kranendonk, M.J., 2010, Two types of Archean continental crust_-Plume and plate tectonics on early Earth: American Journal of Science, v. 310, p. 1187-1209.

Van Schmus, W.R., Bickford, M.E., Sims, P.K., Anderson, R.R., Shearer, C.K., and Treves, S.B., 1993, Proterozoic geology of the western midcontinent basement, in Reed, J.C., Jr., and six others, eds., Precambrian-Conterminous U.S.: Geological Society of America Geology of North America, v. C-2, p. 239-259.

Van Schmus, W.R., Bickford, M.E., and Turek, E., 1996, Proterozoic geology of the east-central mid-continent basement, in van der Pluijm, B.A., and Catacosinos, P.A., eds., Basement and basins of eastern North America: Geological Society of America Special Paper 308, p. 7-32.

Van Schmus, W.R., and Hinze, W.J., 1985, The Midcontinent rift system: Annual Reviews of Earth and Planetary Science, v. 13, p. $345-383$.

Van Schmus, W.R., Schneider, D.A., Holm, D.K., Dodson, S., and Nelson, B.K., 2007, New insights into the southern margin of the Archean-Proterozoic boundary in the northcentral United States based on U-Pb, Sm-Nd, and Ar-Ar geochronology: Precambrian Research, v. 157, p. 80-105.

van Staal, C.R., 2007, Pre-Carboniferous tectonic evolution and metallogeny of the Canadian Appalachians, in Goodfellow, W.D., ed., Mineral resources of Canada-A synthesis of major deposit types, district metallogeny, the evolution of geological provinces, and exploration methods: St. John's, Newfoundland, Mineral Deposit Division of the Geological Association of Canada and the Geological Survey of Canada, p. 793-818.

van Staal, C.R., Dewey, J.F., Mac Niocaill, C., and McKerrow, W.S., 1998, The Cambrian-Silurian tectonic evolution of the Northern Appalachians and British Caledonides-History of a complex, west and southwest Pacific-type segment of Iapetus in Blundell, D.J., and Scott, A.C., eds., Lyell—-The past is the key to the present: Geological Society Special Publications, v. 143, p. 199-242. 
van Staal, C.R., Whalen, J.B., Valverde-Vaquero, P., Zagorevski, A., and Rogers, N., 2009, Pre-Carboniferous, episodic accretion-related, orogenesis along the Laurentian margin of the northern Appalachians: Geological Society, London, Special Publications, v. 327, no. 1, p. 271-316; doi:10.1144/SP327.13.

Viele, G.W., and Thomas, W.A., 1989, Tectonic synthesis of the Ouachita orogenic belt, in Hatcher, R.D., Jr., Thomas, W.A., and Viele, G.W., eds., The Appalachian-Ouachita orogen in the United States: Geological Society of America Geology of North America, v. F-2, chapter 27, p. 695-728.

Villeneuve, M.E., and Theriault, R.J., 1991, U-Pb ages and $\mathrm{Sm}-\mathrm{Nd}$ signature of two subsurface granites from the Fort Simpson magnetic high, northwest Canada: Canadian Journal of Earth Sciences, v. 28, p. 1003-1008.

Vogl, J.J., Foster, D.A., Mueller, P.A., Wooden, J.L., and Mogk, D.W., 2004, Lithology and age of pre-Belt Precambrian basement in the Little Belt Mountains, MontanaImplications for the role of the Great Falls tectonic zone in the Paleoproterozoic assembly of North America: Northwest Geology, v. 33, p. 15-34.

von Huene, Roland, Miller, J.J., and Weinrebe, W., 2012, Subducting plate geology in three great earthquake ruptures of the western Alaska margin, Kodiak to Unimak: Geosphere, v. 8 , p. 628-644.

Wakabayashi, John, and Dumitru, T.A., 2007, ${ }^{40} \mathrm{Ar} /{ }^{39} \mathrm{Ar}$ ages from coherent, high-pressure metamorphic rocks of the Franciscan complex, California-Revisiting the timing of metamorphism of the world's type subduction complex: International Geology Review, v. 49, p. 873-906.

Wallace, W.K., Hanks, C.L., and Rogers, J.F., 1989, The southern Kahiltna terrane-Implications for the tectonic evolution of southwestern Alaska: Geological Society of America Bulletin, v. 101, p. 1389-1407.

Wenz, Z.J., 2005, An investigation of the geology and gold mineralization in the Nyac District, southwest Alaska: Bureau of Land Management Alaska Open-File Report 103, $156 \mathrm{p}$.

White, D.J., Thomas, M.D., Jones, A.G., Hope, J., Németh, B., and Hajnal, Z., 2005, Geophysical transect across a Paleoproterozoic continent-continent collision zone-The Trans-Hudson orogen: Canadian Journal of Earth Sciences, v. 42 , p. $385-402$.

Whitehouse, M.J., Stacey, J.S., and Miller, F.K., 1992, Age and nature of the basement in northeastern Washington and northern Idaho-Isotopic evidence from Mesozoic and Cenozoic granitoids: Journal of Geology, v. 100, p. 691-701.
Whitmeyer, S.J., and Karlstrom, K.E., 2007, Tectonic model for Proterozoic growth of North America: Geosphere, v. 3, p. 220-259; doi: 10.1130/GES00055.1.

Williams, Harold, 1978, Tectonic-lithofacies map of the Appalachian orogen: Memorial University of Newfoundland Map 1A, scale 1:2,000,000.

Williams, M.L., and Karlstrom, K.E., 1996, Looping P-T paths and high-T, low-P middle crust metamorphism: Proterozoic evolution of the southwestern United States: Geology, v. 24, p. 1119-1122.

Wolf, D.E., Leeman, W.P., and Vervoort, J.D., 2005, U-Pb zircon geochronology of crustal xenoliths confirms presence of Archean basement beneath the central and eastern Snake River Plain [abs.]: Geological Society of America Abstracts with Programs, v. 37, p. 60.

Wooden, J.L., Barth, A.P., and Mueller, P.A., 2012, Crustal growth and tectonic evolution of the Mojave crustal province-Insights from hafnium isotope systematics in zircons: Lithosphere; doi: 10.1130/L218.1.

Wooden, J.L., and DeWitt, E., 1991, Pb isotopic evidence for the boundary between the Early Proterozoic Mojave and central Arizona crustal provinces in western Arizona: Arizona Geological Society Digest, v. 19, p. 27-50.

Worthington, L.L., Van Avendonk, H.J.A., Gulick, S.P.S., Christeson, G.L., and Pavlis, T.L., 2012, Crustal structure of the Yakutat terrane and the evolution of subduction and collision in southern Alaska: Journal of Geophysical Research, v. 117, B01102; doi: 10.1029/2011JB008493.

Wright, J.E., and Wyld, S.J., 2006, Gondwanan, Iapetan, Cordilleran interactions-A geodynamic model for the Paleozoic tectonic evolution of the North American Cordillera, in Haggart, J.W., Enkin, R.J., and Monger, J.W.H., eds., Paleogeography of the North American Cordillera-Evidence for and against large-scale displacements: Geological Association of Canada Special Paper 46, p. 377-408.

Wyld, S.J., and Wright, J.E., 2001, New evidence for Cretaceous strike-slip faulting in the United States Cordillera and implications for terrane-displacement, deformation patterns, and plutonism: American Journal of Science, v. 301, p. 150-181.

Wyman, D.A., O'Neill, C., and Ayer, J.A., 2008, Evidence for modern-style subduction to $3.1 \mathrm{Ga}-\mathrm{A}$ plateau-adakite-gold (diamond) association, in Condie, K.C., and Pease, V., eds., When did plate tectonics begin on planet Earth?: Geological Society of America Special Paper 440, p. 129-148; doi: 10.1130/2008.2440(06). 


\section{$\frac{\mathbb{2}}{3}$}

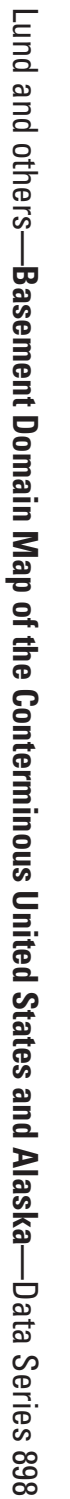

